Article

\title{
Zircon U-Pb Dating of Magmatism and Mineralizing Hydrothermal Activity in the Variscan Karkonosze Massif and Its Eastern Metamorphic Cover (SW Poland)
}

\author{
Stanisław Z. Mikulski ${ }^{1, *(\mathbb{C}}$, Ian S. Williams ${ }^{2}$ (D) Holly J. Stein ${ }^{3,4}$ and Jan Wierchowiec ${ }^{5}$ (i) \\ 1 Polish Geological Institute-National Research Institute, Rakowiecka 4, 00-975 Warszawa, Poland \\ 2 Research School of Earth Sciences, Australian National University, Canberra, ACT 2600, Australia; \\ Ian.Williams@anu.edu.au \\ 3 AIRIE Program, Colorado State University, Fort Collins, CO 80523-1482, USA; Holly.Stein@colostate.edu \\ 4 Institute of Geosciences, University of Oslo, P.O. Box 1047, 0316 Oslo, Norway \\ 5 Faculty Geology, Warsaw University, Żwirki i Wigury 93, 02-089 Warszawa, Poland; \\ Jan.Wierchowiec@uw.edu.pl \\ * Correspondence: stanislaw.mikulski@pgi.gov.pl; Tel.: +48-224592235
}

Received: 29 June 2020; Accepted: 4 September 2020; Published: 7 September 2020

\begin{abstract}
SHRIMP (Sensitive high resolution ion microprobe) zircon $\mathrm{U}-\mathrm{Pb}$ dating of the two main igneous rocks types in the Karkonosze Pluton, porphyritic and equigranular monzogranite, yield ${ }^{206} \mathrm{~Pb} /{ }^{238} \mathrm{U}$ ages between $312.0 \pm 2.9$ and $306.9 \pm 3.0 \mathrm{Ma}$. These coincide, within uncertainty, with the majority of previous dates from the pluton, which indicate development of the main magmatic processes between ca. 315 and 303 Ma. They also coincide with molybdenite and sulfide Re-Os ages from ore deposits developed during magmatic and pneumatolitic-hydrothermal (e.g., Szklarska Poreba Huta and Michałowice) or/and metasomatic and hydrothermal (e.g., Kowary, Czarnów and Miedzianka) processes forming Mo-W-Sn-Fe-Cu-As-REE-Y-Nb-Th-U mineralization. $\mathrm{The}{ }^{206} \mathrm{~Pb} /{ }^{238} \mathrm{U}$ zircon age of $300.7 \pm 2.4 \mathrm{Ma}$ from a rhyolite porphyry dyke (with disseminated base metal sulfide mineralization) in the Miedzianka Cu-(U) deposit coincides with the development of regional tectonic processes along the Intra-Sudetic Fault. Moreover, at the end-Carboniferous, transition from a collisional to within-plate tectonic setting in the central part of the European Variscides introduced volcanism in the Intra-Sudetic Basin. Together, these processes produced brecciation of older ore mineralization, as well as metal remobilization and deposition of younger mediumand low-temperature hydrothermal mineralization (mainly $\mathrm{Cu}-\mathrm{Fe}-\mathrm{Zn}-\mathrm{Pb}-\mathrm{Ag}-\mathrm{Au}-\mathrm{Bi}-\mathrm{Se}$, and Th-U), which became superimposed on earlier high-temperature Mo-W-Sn- Fe-As-Cu-REE mineralization. A few ${ }^{206} \mathrm{~Pb} /{ }^{238} \mathrm{U}$ ages $>320 \mathrm{Ma}$ remain to be reconciled, but might be due to the high $\mathrm{U}$ and $\mathrm{Th}$ contents of the zircon and the strong influence of overprinting pneumatolitic-hydrothermal processes.
\end{abstract}

Keywords: Variscan magmatism; SHRIMP U-Pb zircon geochronology; Re-Os geochronology; intrusion related Mo-W-Sn- Fe-Cu-As-REE-Th-U mineralization; Karkonosze Pluton; Sudetes

\section{Introduction}

$\mathrm{U}-\mathrm{Pb}$ isotopic studies of zircon and monazite from Variscan granitoids that belong to the composite Karkonosze Pluton in the Sudetes have yielded ${ }^{206} \mathrm{~Pb} /{ }^{238} \mathrm{U}$ ages ranging between $322 \pm 3$ and $302.2 \pm 6.4 \mathrm{Ma}$ [1]. This range of U-Pb ages from essentially the same intrusive body has been explained by the presence of inherited zircon grains, and disturbance of the U-Pb isotopic system due to zircon metamictization or late and post-magmatic and metamorphic alteration processes [1-3] 
that are also common in different mining sites [4]. Here we report the results of a SHRIMP U-Pb study of zircon from igneous rocks from areas with pneumatolitic-hydrothermal ore mineralization (Mo-W-Sn-REE-Fe-Cu-As-Th-U) in the central part of the Karkonosze pluton, as well as from its eastern margin, along contacts with metamorphic rocks. These igneous rocks host polymetallic ore mineralization, for example the Miedzianka $\mathrm{Cu}(-\mathrm{U})$ and Czarnów As-Fe deposits. We compare the results of our study with $\mathrm{U}-\mathrm{Pb}$ ages obtained by other authors, and discuss the implications. We also discuss the U-Pb results in relation to Re-Os ages of molybdenite and cobaltiferous arsenopyrite crystallization from the same areas [5,6]. Similar comparisons between $\mathrm{U}-\mathrm{Pb}$ and $\mathrm{Re}-\mathrm{O}$ s isotope data for a succession of magmatic processes and ore mineralization show a clear temporal relationship between felsic magmatism and the formation of Mo-W-Cu deposits elsewhere in the Variscides of central Europe $[7,8]$.

\section{Geological Setting}

The Karkonosze pluton (Krkonoše-Jizera pluton according to Czech nomenclature) forms the core of the Karkonosze-Izera Massif (KIM). It is located in the northern part of the Bohemian Massif, within the NE extension of the Saxothuringian Zone of the central European Variscides (Figure 1), [9]. The post-collisional Karkonosze pluton is surrounded by metamorphic rocks that are interpreted to be a succession of four structural units/nappes: (1) the Izera-Kowary Unit, (2) the Ješted Unit, (3) the Southern Karkonosze Unit, and (4) the Leszczyniec Unit [10]. These individual lithostratigraphic units were formed in different, distant geotectonic environments and it was only during the Variscan orogeny that the units were thrusted, forming a stack of nappes [11]. The uppermost unit in the stack is the Leszczyniec Unit, forming the eastern metamorphic cover of the pluton. In the following sections a short geological and mineralogical review of the studied sites is presented.

\subsection{Karkonosze Pluton}

The Late Carboniferous Karkonosze pluton (KP), which is about $70 \mathrm{~km}$ long (W-E) and 8 to $20 \mathrm{~km}$ wide, is the largest exposed granite body in the Sudetes, occupying $1000 \mathrm{~km}^{2}$ (Figure 1). The NE side of the KP is cut by the Intra-Sudetic Fault (ISF), a regional-scale strike-slip fault zone parallel to the Teisseyre-Tornquist Line that defines the SW edge of the East-European Platform (Figure 1, lower inset). The KP is surrounded by variably metamorphosed Neoproterozoic and Early Palaeozoic supracrustal series [12]. To the north are the metamorphic rocks of the Jizera Mountains, to the east and south are the crystalline series of the eastern Karkonosze (or Rudawy Janowickie) and the sequences of the Rychorskie Mountains and southern Karkonosze. This meta-sedimentary series is accompanied by gneisses (metamorphosed Cambrian-Ordovician granites), in different regions called the Jizera, Kowary or Karkonosze gneisses $[13,14]$. The emplacement of the Karkonosze pluton followed extensional collapse along a regional suture zone located within the eastern metamorphic cover of the pluton (possibly a fragment of the Tepla/Saxothuringian suture) [10,12]. The KP has been classified as a post-collisional $S$ - or I-type granite [15-17]. The Karkonosze granites included in the present study are weakly peraluminous rocks, with $\mathrm{A} / \mathrm{NK}\left(\left(\mathrm{Al}_{2} \mathrm{O}_{3} /\left(\mathrm{Na}_{2} \mathrm{O}+\mathrm{K}_{2} \mathrm{O}\right)\right)\right)$ ratios of $1.0-1.4$, and $\mathrm{A} / \mathrm{CNK}$ $\left(\left(\mathrm{Al}_{2} \mathrm{O}_{3} /\left(\mathrm{CaO}+\mathrm{Na}_{2} \mathrm{O}+\mathrm{K}_{2} \mathrm{O}\right)\right)\right)$ ratios of 1.0-1.2. Detailed petrological studies of the KP have shown complex genetic relationships between the various granite types, including different contributions from crustal and mantle magma sources, and subsequent differentiation processes involving magma mixing and fractional crystallization $[17,18]$.

Two main textural types of granite can be distinguished. These are: (1) the "central granite", porphyritic coarse- and medium-grained granite occupying the main part of the pluton, and (2) the "ridge granite", equigranular fine- and medium-grained granite that forms the highest parts of the Karkonosze Mountains [18]. The porphyritic granites are mostly magnesian, whereas the equigranular granites are ferroan [22]. Both granite facies are calc-alkalic, with some alkali-calcic occurrences [1]. Pockets of biotite granite with granophyric texture are present in places within the equigranular granite. The porphyritic granite is rich in various types of hybrid enclaves, mostly MME (mafic microgranular 
enclaves), and in small isolated bodies of hybrid quartz diorite and granodiorite [17]. Subordinate varieties of KP granites include (a) aplogranite (the "granophyric granite") displaying a granophyric matrix and feldspar phenocrysts, which is poorly exposed within the porphyritic facies in the NE part of the pluton; (b) pale, medium-grained two-mica granite (the "Tanvald granite" type) of local extent at the SW margin of the pluton; and (c) fine-grained porphyritic granodiorite (the "Fojtka granite" type), forming a range of small bodies NE of Liberec (Figure 1) [18,23].

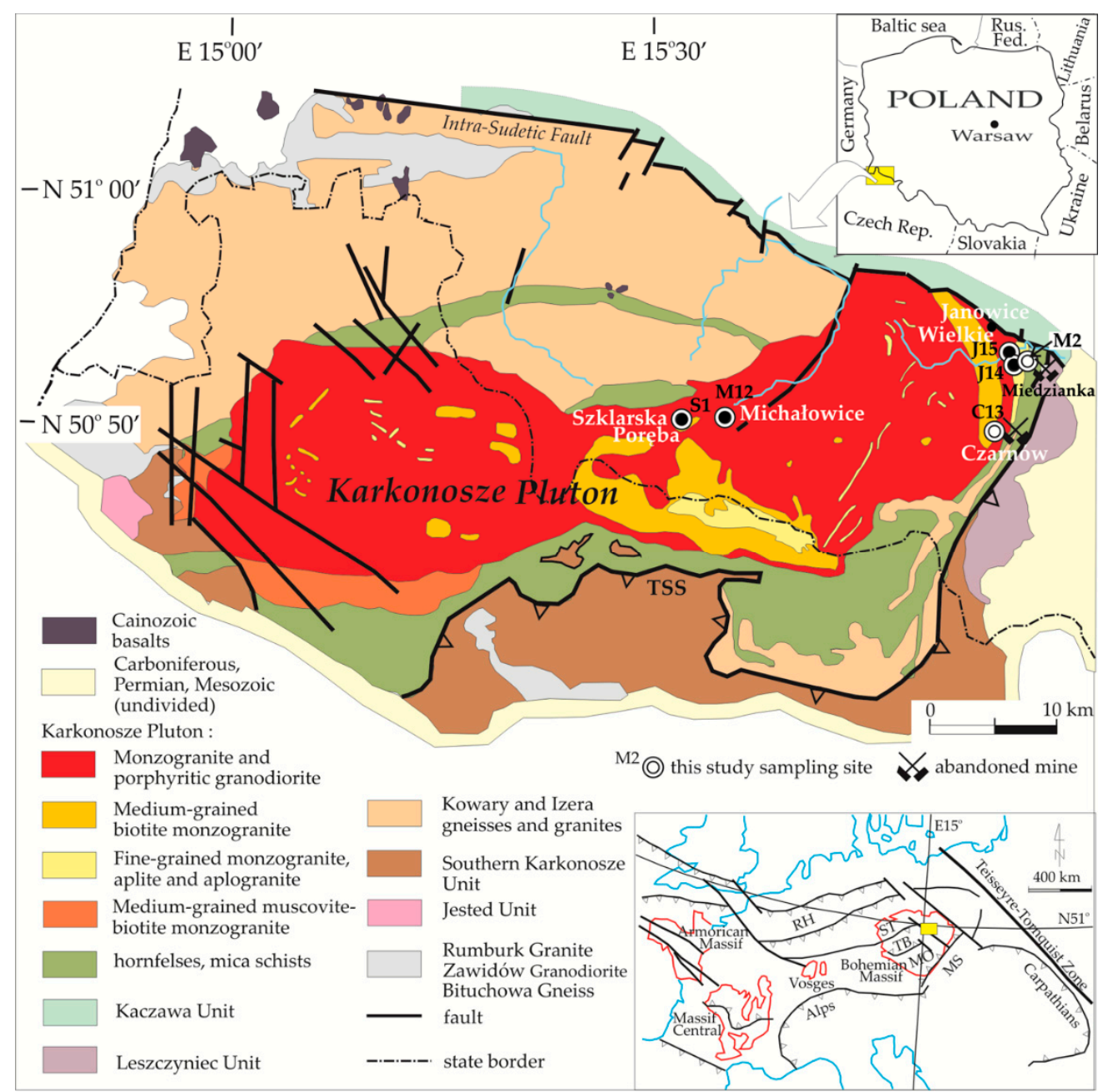

Figure 1. Geological sketch map of the Karkonosze-Izera Massif and the general location of sampling sites for this study (compilation based on $[12,19,20]$ ). The yellow rectangles on two insert maps show the area of the main map. Abbreviations: MO-Moldanubian Zone, MS-Moravo-Silesian Zone, RH-Rhenohercynian Zone, ST-Saxothuringian Zone, TB-Tepla-Barrandian Zone, TSS-Tepla-Saxothuringian Suture (inferred eastern continuation modified from [21]).

On the basis of the alignment of feldspar and the strike of biotite schlieren, Cloos (1925; [24]) recognized two major directions of magmatic flow and granite domes (Strużnica and Karkonosze).

The multiphase intrusion of the Karkonosze pluton was confirmed by several researchers [17,25-27]. The model of granite emplacement proposed by Žák and Klomínský [26] involved "chamber-wide mixing and hybridization" followed by "laminar magma flow in highly localized weaker channel-like domains within the higher-strength crystal framework", and later, complex processes of schlieren and dyke formation. Two main mechanisms played a prominent role in the Karkonosze massif magma differentiation: (1) mixing of coeval mafic and felsic magmas in the early stages of pluton formation (porphyritic granites) and (2) fractional crystallization of the more evolved melts (equigranular 
granite facies) [17,28]. Kennan and others [29] suggested that the low ${ }^{87} \mathrm{Sr} /{ }^{86} \mathrm{Sr}$ of the Karkonosze granite indicates that the parent magma did not result from melting of the gneisses exposed in the Karkonosze-Izera region. The KP is cut by large lamprophyre dyke swarms that are found in the eastern and western parts of the massif $[18,21]$. Four generations of vein type rocks (granitoid apophyses and dykes, as well as aplites, pegmatites and quartz-feldspar veins) genetically related to the KP are distinguished within the KP and in its northern contact zones [30]. The first and second generations are thought to be syn-intrusive, whereas the third and fourth generations are post-intrusive. Aplite veins of the last generation are related to the latest stages of pluton evolution after the margins were solidified, but magma remained near the center. The KP magmas are strongly evolved and fractionated, making them a potential source of metals such as Mo-W-Sn-REE-Nb-Y-U-Th [16]. Within the KP and its immediate vicinity, numerous mineral occurrences of Mo-W-Sn-Bi and Th-U-REE, and abandoned As-Cu-Fe polymetallic deposits, are genetically related to the pluton [31].

\subsection{Previous Dating of KP Igneous Rocks}

Dating of the $\mathrm{KP}$ using the $\mathrm{Rb} / \mathrm{Sr}$ whole rock isochron method [32,33] yielded ages of $328 \pm 12 \mathrm{Ma}$ for the older, porphyritic "central granite", $309 \pm 3$ Ma for the younger, equigranular "ridge granite", and $310 \pm 13$ Ma for a vein of leucocratic "granophyric granite" (Appendix A). Porphyritic granite from the Michałowice quarry gave an age of $329 \pm 17 \mathrm{Ma}$ [33]. The ${ }^{40} \mathrm{Ar} /{ }^{39} \mathrm{Ar}$ method yielded an age of $320 \pm 2$ Ma for the porphyritic "Liberec granite" and $315 \pm 2$ Ma for the medium- and fine-grained granite [34]. The porphyritic granite contains numerous mafic schlieren and enclaves, which gave an age of ca. $350 \mathrm{Ma}$ [33]. Conventional multigrain zircon $\mathrm{Pb}-\mathrm{Pb}$ and $\mathrm{U}-\mathrm{Pb}$ dating yielded a ${ }^{206} \mathrm{~Pb} /{ }^{238} \mathrm{U}$ age of $304 \pm 14$ Ma for a porphyritic monzogranite [35]. SHRIMP zircon U-Pb dating of Karkonosze granitoids yielded Late Carboniferous ${ }^{206} \mathrm{~Pb} /{ }^{238} \mathrm{U}$ ages: $314.0 \pm 3.3 \mathrm{Ma}$ and $318.5 \pm 3.7 \mathrm{Ma}$ for porphyritic granites from the NE part of the pluton [2], and between 302.2 \pm 6.4 and $314 \pm 4.8 \mathrm{Ma}$ for various types of the granite elsewhere [3,36-39]. Refined ${ }^{206} \mathrm{~Pb} /{ }^{238} \mathrm{U}$ dating of unabraded zircons from the Szklarska Poręba Huta porphyritic granite gave $306 \pm 4 \mathrm{Ma}$, while chemically abraded zircon yielded an age of $322 \pm 3 \mathrm{Ma}$ [40], that is, close to the earlier Rb-Sr results [32,33]. High-precision CA-ID-TIMS zircon ages provide evidence that the two main granite facies, porphyritic and equigranular, crystallized between $312.5 \pm 0.3$ and $312.2 \pm 0.3 \mathrm{Ma}$ [1]. A zircon U-Pb study of the southern part of the KP by laser ablation ICPMS dated a wider variety of granite facies, revealing a somewhat older time span of ca. 320-315 Ma for granite emplacement [27]. Locally the Karkonosze granitoids are cut by numerous lamprophyre and other dykes. One of them, the micromonzodiorite dyke from the Karpacz-Janowice Wielkie dyke swarm near Kowary, was dated by SHRIMP zircon U-Pb at $313 \pm 3 \mathrm{Ma}$ [21]. SHRIMP monazite $\mathrm{U}-\mathrm{Th}-\mathrm{Pb}$ dating of a wide variety of lithologies, including porphyritic and hybrid granitoids, and composite dykes, gave ages in the range ca. 314-311 Ma [39,40], consistent with the indications from U-Pb zircon CA-ID-TIMS data [1] that the bulk of the KP magmatism was relatively short-lived.

\section{Geological and Mineralogical Characteristics of the Sampling Sites}

\subsection{The Szklarska Poręba Huta Building Stone Quarry}

The Szklarska Poreba Huta granite quarry is located in the western part of the KP close to its contact with the Izera Mountains metamorphic cover (Figure 1). The quarry contains finely crystalline (equigranular) aplogranite hosted in an older, porphyritic variety and medium- and coarse-grained monzogranite. All are locally cut by aplite veins, pegmatite bodies and quartz veins and veinlets with Mo-W-Sn-Bi-Fe-As-Cu-S mineralization [16,31,41-51], and U-Th and REE mineralization [47,49]. Most ore mineralization is found in the northwestern part of the quarry, in quartz veins (with ores) from 1 to $25 \mathrm{~mm}$ thick. They mostly have a meridional strike and almost vertical dip.

The dominant ore minerals are chalcopyrite, pyrite and molybdenite, accompanied by wolframite, scheelite, cassiterite, native bismuth, bismuth sulfosalts as well as native Ag, Ti, Fe and Ti oxides (Figure 2A-C). Molybdenite occurs in quartz veinlets and as disseminations in aplogranite [49]. 
In addition, there is an association of $\mathrm{U}$-Th minerals with rare minerals of $\mathrm{REE}, \mathrm{Y}, \mathrm{Nb}, \mathrm{Zr}$, and Li. The aplogranite hosting the quartz veinlets is silicified, sericitized, chloritized and albitized. Some elements are enriched in the altered granitoid (e.g., up to ca. 2500 ppm W, 50 ppm U, and/or $40 \mathrm{ppm} \mathrm{Th)} \mathrm{[16].} \mathrm{This} \mathrm{ore} \mathrm{mineralization} \mathrm{is} \mathrm{related} \mathrm{to} \mathrm{a} \mathrm{long-lasting} \mathrm{hydrothermal} \mathrm{system} \mathrm{in} \mathrm{the} \mathrm{KP}$ spanning a narrow temperature range $\left(405-375^{\circ} \mathrm{C}\right)$ during the pneumatolitic stage. A subsequent hydrothermal stage records a wide range of temperatures from 375 to about $100{ }^{\circ} \mathrm{C}$ [50].
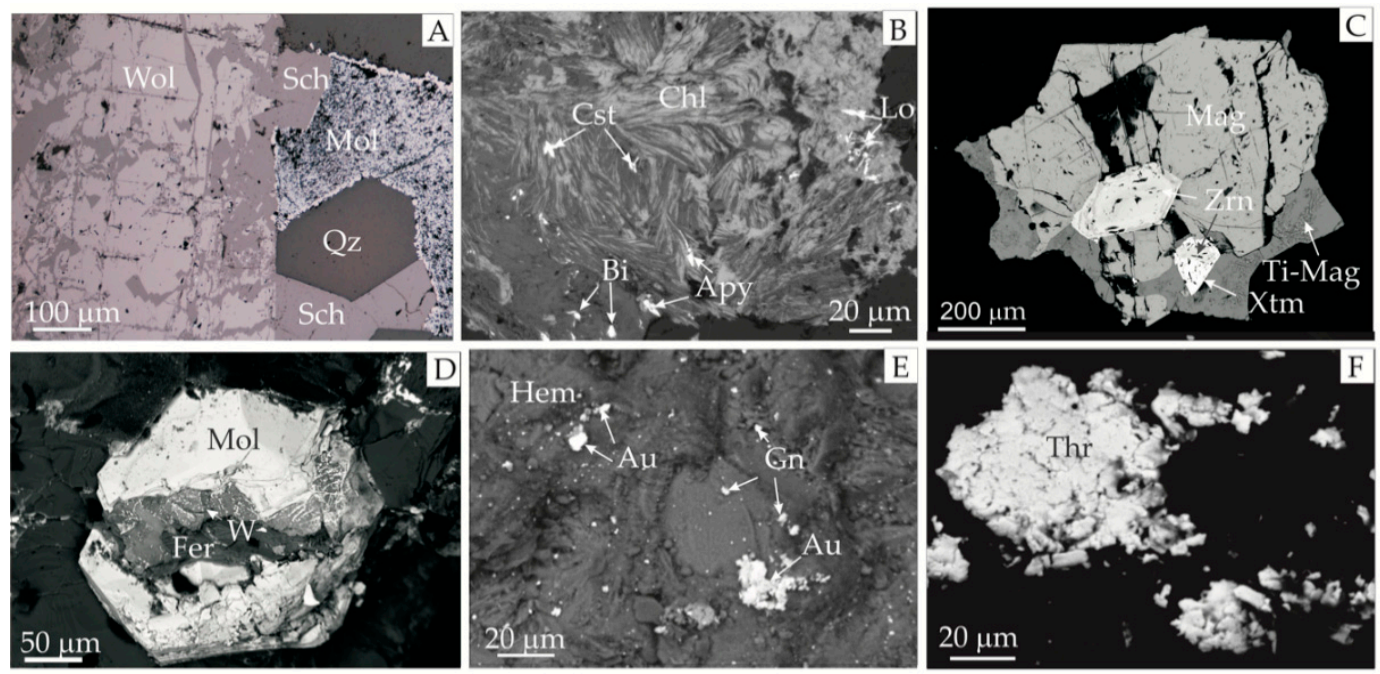

Figure 2. Photomicrographs of ore mineralization from the Szklarska Poręba Huta $(\mathbf{A}-\mathbf{C})$ and Michałowice quarries (D-F). (A) Replacement of wolframite (Wol, hübnerite) by scheelite (Sch) and molybdenite (Mol) by Mo-ochres forming aggregates up to $5 \mathrm{~mm}$ in diameter in a quartz (Qz) veinlet. Reflected light; (B) finely crystalline cassiterite (Cst) in association with chlorite minerals (Chl), native bismuth (Bi), arsenopyrite (Apy) and löllingite (Lo). BSEI (Backscattered Electron Image); (C) titanium-bearing magnetite (Ti-Mag) and magnetite (Mag) in association with zircon (Zrn) and xenotime (Xtm). BSEI; (D) Molybdenite (Mol) hexagonal tablets with ferberite (Fer) and secondary tungsten minerals (W), BSEI; (E) Native gold grains (Au) in paragenetic association with hematite (Hem) and galena (Gn). BSEI; (F) Thorite (Thr) in the form of fine crystalline aggregates associated with hematite. BSEI.

\subsection{The Michatowice Quarry}

The Michałowice quarry is located about $3 \mathrm{~km}$ east of Szklarska Poręba (Figure 1). Extensive mineralization with sulfides of $\mathrm{Mo}, \mathrm{Fe}$, and $\mathrm{Cu}-\mathrm{As}$, as well as minerals bearing $\mathrm{W}$, $\mathrm{Sn}$, Th and REE, occurs in pegmatites and in quartz veins cutting coarse-grained porphyritic granite $[41,43,46,52-54]$. Molybdenite and pyrite dominate in grey quartz veins with variable thickness, from a few $\mathrm{mm}$ to about $2 \mathrm{~cm}$. These veins are almost vertical and mostly have a N-S strike. In addition, ore mineralization is present on fracture surfaces and within cataclastic parts of the porphyritic granite. Molybdenite occurs in quartz-feldspar pegmatite nests as single blades $(<3 \mathrm{~mm}$ ) or small aggregate crystals (up to $5 \mathrm{~mm}$ in diameter). Molybdenite is associated with wolframite (ferberite), scheelite, chalcopyrite, pyrite, native bismuth, bismuthinite, thorite, thucholite, gummite, galena, stolzite and tungstate minerals (Figure 2D-F). Ilmenite in the porphyritic granite is commonly associated with rutile. Chalcopyrite and pyrite are rare and partially replaced by secondary Fe-hydroxides (goethite, malachite and other minerals). Biotite is strongly chloritized, especially along fractured surfaces. 


\subsection{The Eastern Metamorphic Cover of the Karkonosze Pluton}

Based on geochemical and tectonic analysis, several lithostratigraphic units of early Palaeozoic age have been distinguished within the eastern metamorphic cover of the KP (Figure 1; [11,19,20,55-60]). The units are in tectonic contact, and have different lithologies and metamorphic grades, ranging from greenschist facies (south) to amphibolite facies (north). According to Ar-Ar dating of micas [33] the metamorphism occurred during the Famennian to Tournaisian (ca. 375-345 Ma).

The rocks are strongly folded and cut by several faults that generally strike NE-SW, with dips of $65-75^{\circ}$ SE. These units originated in distant geotectonic environments, and were juxtaposed in a prism of nappes during the Variscan orogeny $[11,58]$. The supracrustal sequence in the Kowary-Czarnów unit [58] includes various mica slates and phyllonites, as well as marble inserts, calc-silicate rocks, and metavolcanics-various mafic amphibolites and felsic leptic rocks [59,60]. The upper age limit of the shale series is determined by the intrusion of the protolith of the Kowary gneisses (511-492 Ma; zircon $\mathrm{U}-\mathrm{Pb}$ [13] and $\mathrm{Pb}-\mathrm{Pb}[35,61])$. The youngest (presumably Ordovician or Devonian) rocks of the Kowary-Czarnów Unit are biotite amphibolites that originated from the transformation of gabbros and diorites and now form lenses in the Kowary gneisses.

The Leszczyniec Unit consists exclusively of meta-igneous rocks of a spilite-keratophyre formation of Late Cambrian-Early Ordovician age (501.3 $\pm 3.1 \mathrm{Ma}$ and $494 \pm 2 \mathrm{Ma}$; zircon U-Pb [13,61]). They mostly have a geochemical signature typical of the N-MORB [62]. In the final phase of the Variscan orogeny, a post-kinematic intrusion of the Karkonosze granites was associated with the final phase of the $\mathrm{D}_{2}$ extensional collapse [11]. Magma thermally affected the cover rocks, creating a hornfelsed zone. Further from the main body of the pluton, smaller granitoid, aplite or rhyolite veins were injected. During the $\mathrm{D}_{3}$ deformation event, regional foliation steepened due to rotation around a NNE-SSW-trending axis of the so-called East Karkonosze Monocline [10]. The rotation post-dated emplacement of the KP and affected not only the metamorphic complexes at the eastern margin of the KIM, but also the adjacent Intra-Sudetic Basin. The rocks of the eastern margin units host several abandoned polymetallic ore deposits, especially along the contacts with the KP [31].

\subsubsection{The Janowice Wielkie Area Close to the Miedzianka Cu-Polymetallic (-U) Deposit}

The study area is located in the eastern part of the Karkonosze-Izera Massif (KIM), close to the Intra-Sudetic Fault [12] (Figure 3A). This deposit belongs to the Miedzianka-Ciechanowice mining district, which was exploited from the Middle Ages until the 1950s. The bulk of the ore mineralization occurs in amphibolites, amphibolite or quartz-sericite schists, and skarns belonging to the Kowary-Czarnów Unit near its contact with the KP, but some underground workings in the easternmost part were cut into rocks of the Leszczyniec Unit $[10,58,59]$. These rocks, first metamorphosed to amphibolite grade, have a retrograde greenschist facies overprint [60]. The Western mining field is dominated by a magnetite-sphalerite-pyrite ore genetically connected with skarns, and by numerous small quartz-sulfide veins hosted by Early Palaeozoic volcanic-metasedimentary rocks [63-65]. Four main vein systems, dominated by W-E and NW-SE strikes and steep dips $\left(70-80^{\circ}\right)$ to the N or S-SE, have been distinguished (Figure 3B). They have variable thickness (5-30 cm; maximum $3 \mathrm{~m}$ ) and strike length (up to $200 \mathrm{~m}$ ), and depth (100-120 m). 


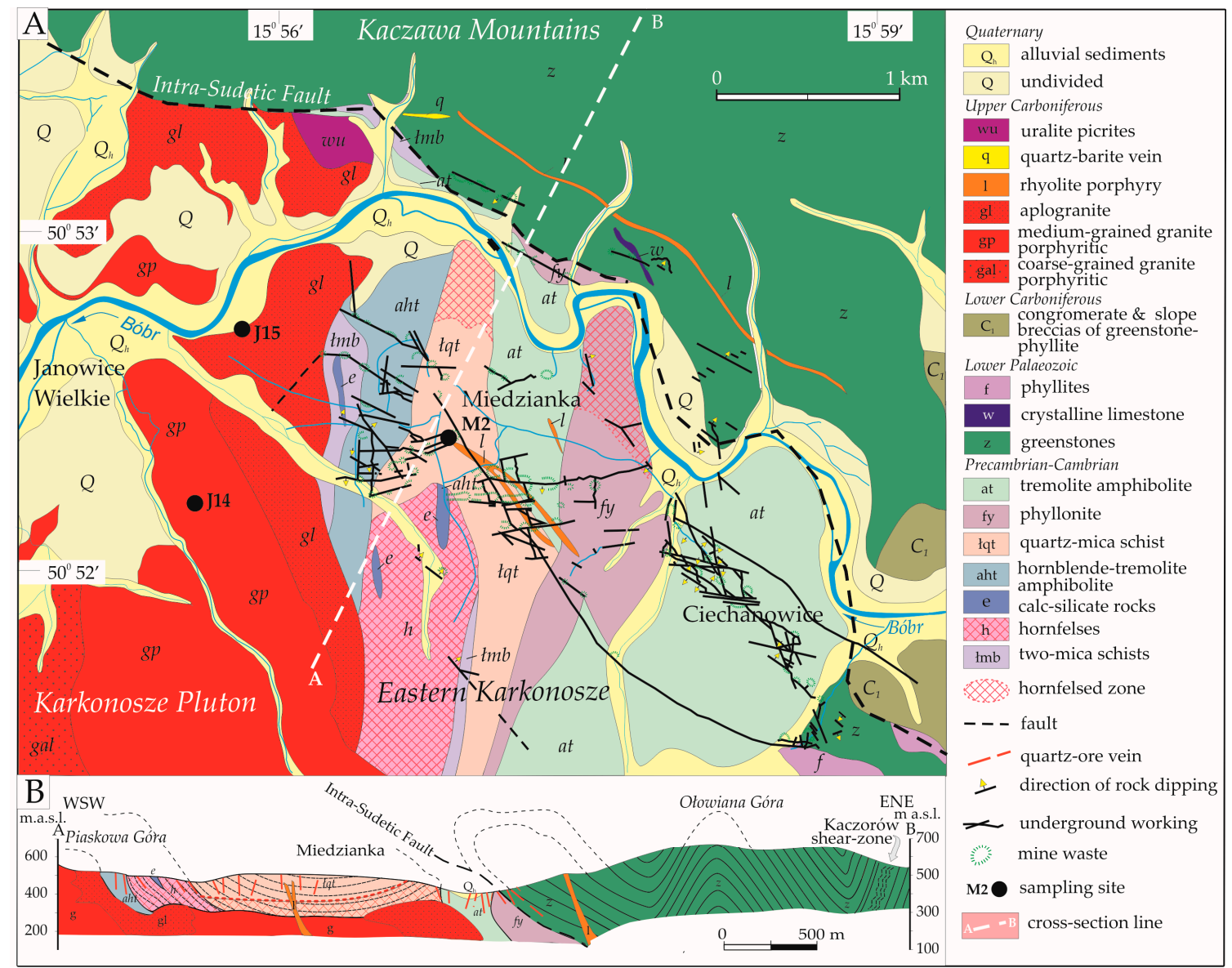

Figure 3. Geological sketch map with sampling sites (A) after [66] with mine workings and waste compiled from unpublished mining documents. (B) Geological cross-section of the Miedzianka deposit and its surroundings after [66].

The quartz ore veins are composed mainly of chalcopyrite and bornite, accompanied by uraninite mineralization $[63,67]$. In the remaining mining fields, only polymetallic ore mineralization occurs. Commonly it consists of chalcopyrite, sphalerite, bornite, chalcocite, arsenopyrite (Figure 4A-E), tetrahedrite-tennantite, and As, Co and Bi ore minerals, sometimes accompanied by electrum, wolframite, cassiterite, silver, and silver amalgamates, and numerous rare sulfosalt minerals (Figure 4F-I), [63,68,69]. These minerals are accompanied by small amounts of barite, fluorite, and chlorite. In the Northern field there are also quartz-barite veins with base metal sulfides. The most common secondary minerals of the mining dumps are chrysocolla accompanied by malachite, sometimes cuprite and various secondary arsenates (cornwallite-Pseudomlalachite, philipsburgite, olivenite, bayldonite, brochantite, langite and devilline [70-72]. Formation of the $\mathrm{Cu}$ sulfide-bearing quartz veins was connected with post-magmatic hydrothermal activity around the KP [30,63,65], although earlier stages of ore precipitation also have been recognized [65]. 

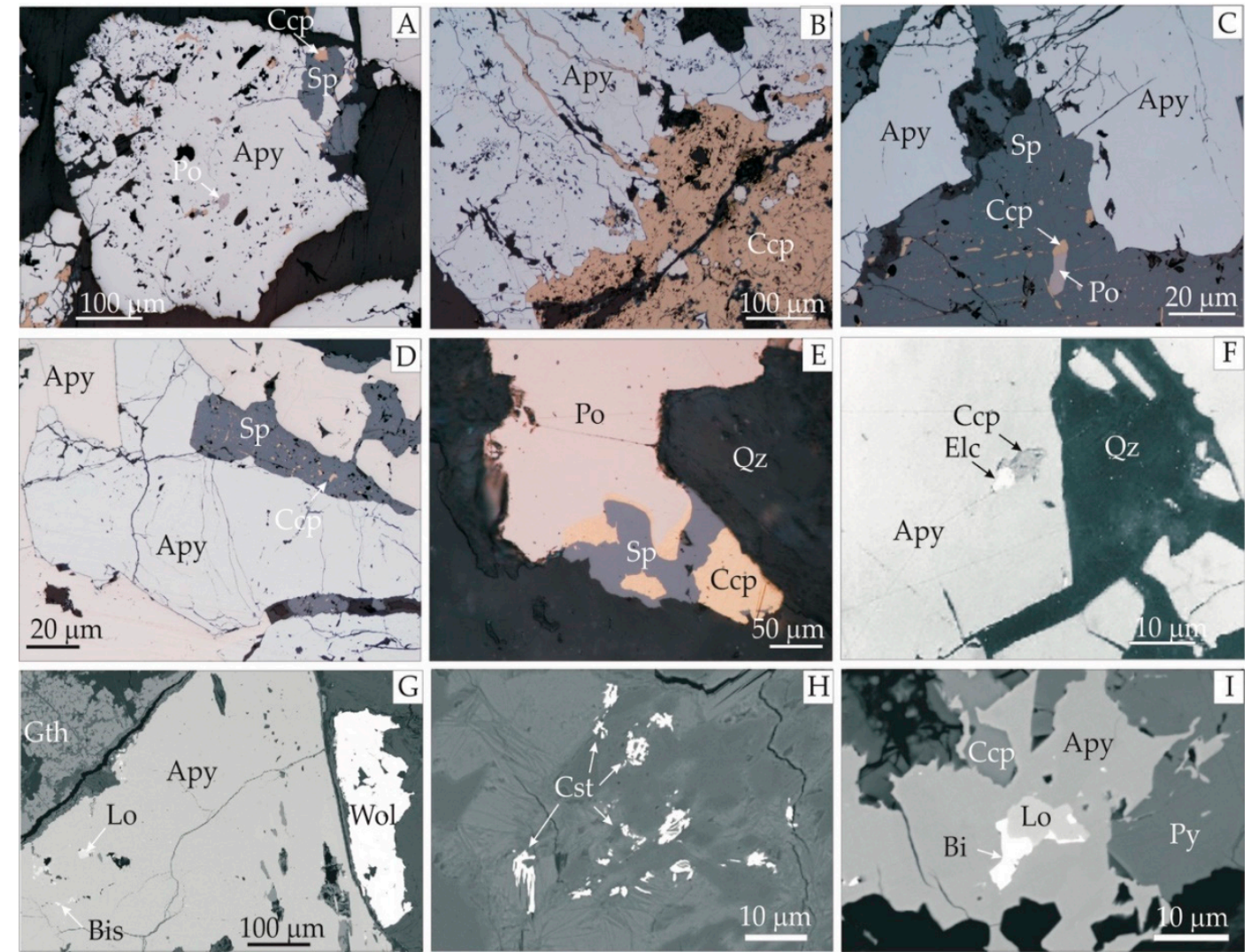

Figure 4. (A-F) Photomicrographs under reflected light of ore mineralization from the Miedzianka $\mathrm{Cu}(-\mathrm{U})$ deposit. (A) Characteristic poikilitic texture of arsenopyrite (Apy) and rare inclusions of pyrrhotite (Po) and ore-free minerals and sphalerite overgrowths (Sp); (B-D) Common features of the ore mineralization from the Eastern Karkonosze are fractured arsenopyrite (Apy) aggregates overprinted by base metal sulfides, e.g., mainly by chalcopyrite (Ccp) in association with sphalerite (Sp) and pyrrhotite (Po); (E) Overgrowths of pyrrhotite (Po) by chalcopyrite (Ccp) with sphalerite (Sp) and quartz (Qz); (F) Fine electrum (Elc) and chalcopyrite (Ccp) intergrowths in fractured arsenopyrite (Apy) massive ore cemented by quartz $(\mathrm{Qz})$; $(\mathrm{G})$ wolframite (Wol) (ferberite: $\mathrm{WO}_{3}-77.8$ wt.\%; FeO-21.2 wt.\%; $\mathrm{MnO}-0.4 \mathrm{wt} . \%$ ) in association with arsenopyrite (Apy) and goethite (Gth). In arsenopyrite fine inserts of bismuthinite (Bis) and löllingite (Lo); (H) disseminated fine xenomorphic crystals of cassiterite (Cst); (I) intergrowths of arsenopyrite (Apy) with pyrite (Py) and chalcopyrite (Ccp). Arsenopyrite contains finely disseminated intergrowths of native bismuth (Bi) and löllingite (Lo).

\subsubsection{The Czarnów As-Polymetallic Deposit}

At the Czarnów deposit (Figure 5), a steeply dipping ( $\left.80^{\circ} \mathrm{SE}\right)$ quartz-ore vein is hosted by rocks belonging to the Kowary-Czarnów Unit [56]. They are bounded to the west by the KP, a medium-grained phase, and to the east (along a dislocation) by the Leszczyniec unit (Figure 5A). The unit has a local thickness of about $1 \mathrm{~km}$, and extends NNE-SSW with a steep dip (65-80 ) towards SE and S. A belt of orbicular and laminated Kowary gneiss 50-200 m wide is adjacent to the granite. The dominant lithology in the western (bottom) part of the unit is contact metamorphosed mica schist. There are intercalations of crystalline dolomites, calc-silicate rocks, skarns, biotite amphibolites and leptinites, and in the eastern (top) part, of diopside-hornblende amphibolites [60]. The quartz-ore vein is $0.5-3 \mathrm{~m}$ thick, about $500 \mathrm{~m}$ long and has a SW-NE strike. It was mined to a depth of ca. $200 \mathrm{~m} \mathrm{[31,73-76].}$ The vein divides into 2 or 3 parts through the depth interval ca. 780-670 $\mathrm{m}$ a.s.l., giving the deposit a lenticular form (Figure 5B). Numerous cracks and faults cross the vein, the most important of which are NW-SE directed (perpendicular to the foliation) sinistral and dextral strike-slip faults that dislocate the ore zone. 


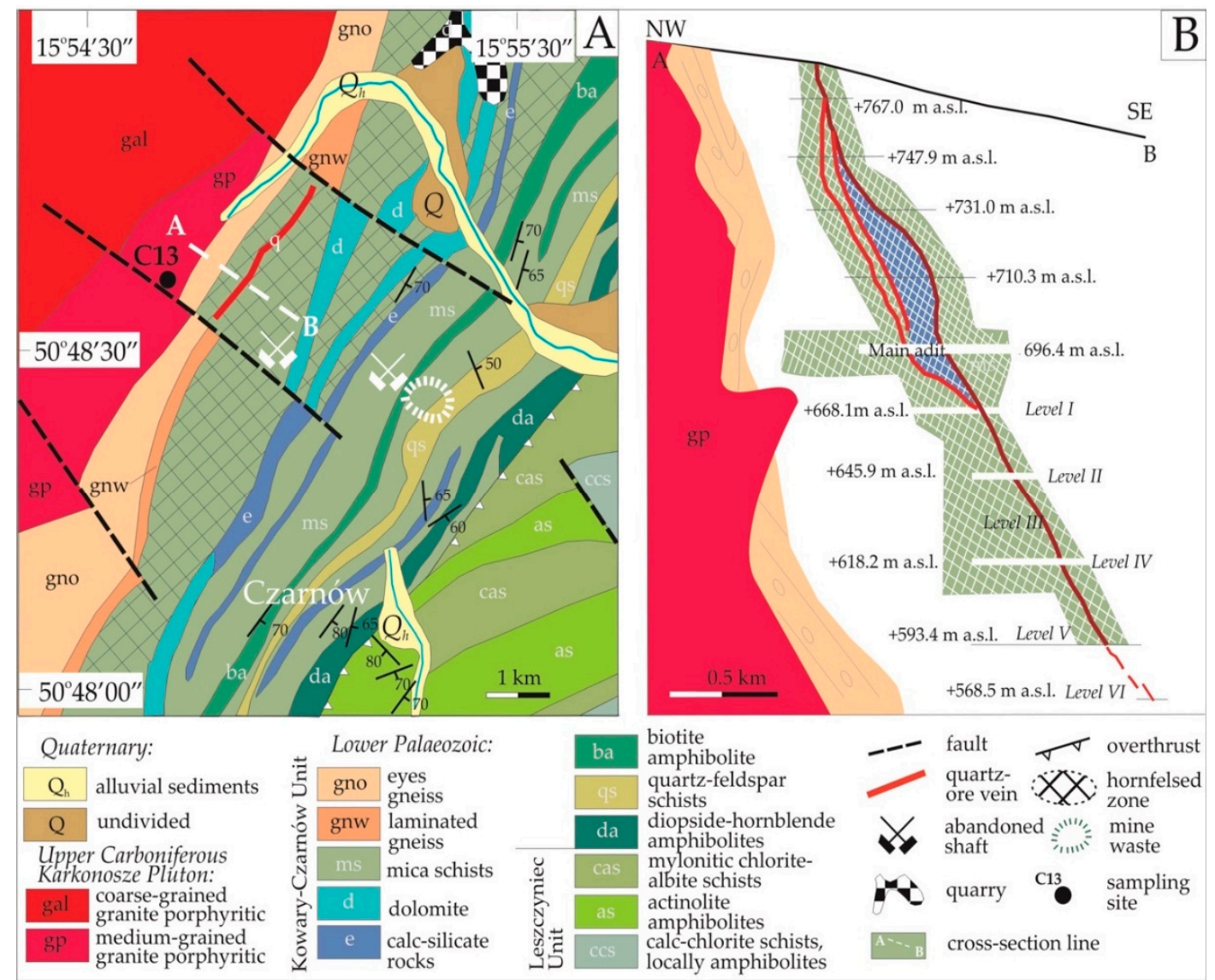

Figure 5. (A) Geological map of the Czarnów deposit area with location of the sampling site (C13) modified from [77]; (B) Schematic geological cross-section through the Czarnów As-polymetallic deposit.

The ore mineralization is composed mostly of massive or coarse-grained euhedral crystals of arsenopyrite and pyrrhotite that form lens-like bodies within the main quartz vein, or semi-massive impregnations that form lens-like bodies in the country rocks (Figure 6A,B). As a rule, massive arsenopyrite intergrowths with patches of fine-grained pyrrhotite, pyrite and chalcopyrite (up to $1.5 \mathrm{~cm}$ in size) were mined, as well as local enrichments of stibnite, cassiterite, magnetite or galena with sphalerite (Figure 6C-E). Native gold occurs together with electrum (Figure 6F), as well as Bi- and Ag-minerals as fine inclusions (up to $20 \mu \mathrm{m}$ in size) and micro-veinlets within sulfides [75]. Other minerals present are: bornite, marcasite, tennantite, valleriite, cubanite, covellite, chalcocite, goethite, limonite, scorodite, digenite, rutile and leucoxene [73]. Gangue minerals are mainly quartz and to a lesser extent calcite, dolomite, feldspar, chlorite and amphibole. Crystallization temperatures of the quartz-sulfide (massive arsenopyrite-pyrrhotite-pyrite) ore veins were in the range ca. $550-200{ }^{\circ} \mathrm{C}$ (Mikulski, unpublished data). Two separate generations of early formed cassiterite crystallized at temperatures of $440-384^{\circ} \mathrm{C}$ and $340-300{ }^{\circ} \mathrm{C}$ at a pressure of $1.2-1.1 \mathrm{kbar}$ from a fluid with total salinity 24-16 wt.\% of $\mathrm{NaCl}$ equivalent [74]. Several stages of ore crystallization have been identified, at least the main two of which were genetically associated with contact metasomatic and post-magmatic activity in the KP [31,73-76]. 

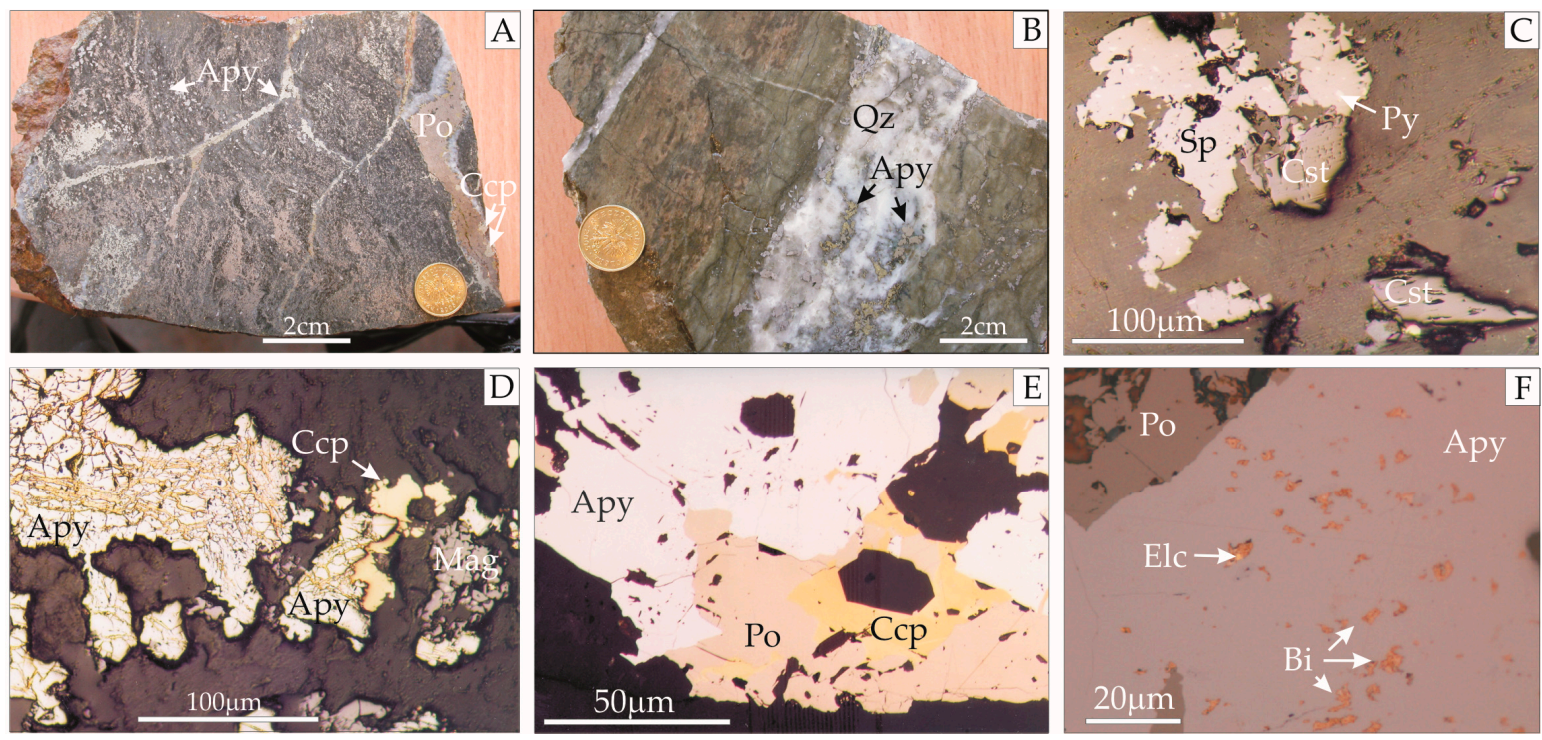

Figure 6. (A-F) Typical ore mineralization from the Czarnów As-polymetallic deposit: (A) macro-photographs of fractured massive pyrrhotite (Po) ore with chalcopyrite ( $\mathrm{Ccp}$ ) cemented by younger generation arsenopyrite (Apy); (B) Arsenopyrite (Apy) disseminated mineralization in quartz vein (Qz) hosted by calc-silicate skarn; (C) Photomicrograph under reflected light of fine-grained aggregates of cassiterite (Cst) and sphalerite (Sp), which contains disseminated pyrite (Py); (D) Highly fractured arsenopyrite cemented by chalcopyrite (Ccp), with associated magnetite (Mag); (E) finely crystalline sulfide aggregate of arsenopyrite (Apy), pyrrhotite (Po), and chalcopyrite (Ccp); (F) finely disseminated electrum (Elc) and native bismuth and bismuth minerals $(\mathrm{Bi})$ hosted by massive arsenopyrite (Apy) and pyrrhotite ore $(\mathrm{Po})$.

\section{Samples for U-Pb Dating}

Three samples of porphyritic ("central") granite, two of equigranular ("ridge") granite and one of rhyolite porphyry were collected for zircon $\mathrm{U}-\mathrm{Pb}$ dating. The granite samples came from the central part of the KP, as well as from the eastern margin along the contact with the rocks of the eastern metamorphic cover ( Figures 1,3A and 5A, Appendix B). The rhyolite sample was collected from the mine waste of the abandoned underground workings of the Miedzianka Cu-polymetallic deposit (Figure 3A).

The porphyritic monzogranite samples (M12, J14, C13) have a medium- to coarse-grained matrix composed of pink K-feldspar, whitish plagioclase, grey quartz and minor biotite (Figure 7A). The matrix encloses large euhedral phenocrysts of K-feldspar, usually with Carlsbad twinning and whitish plagioclase rims (rapakivi-type), and much rarer, smaller plagioclase phenocrysts. The rocks are porphyritic to varying degrees. Feldspar phenocrysts commonly reach $10-30 \mathrm{~mm}$ diameter, and sporadically up to $70 \mathrm{~mm}$. They are usually pink, but also white or white-beige. The granite contains anhedral quartz (30-40 vol. \%), anhedral-subhedral K-feldspar (10-30 vol. \%), subhedral-euhedral plagioclase (25-35 vol. \%), biotite (5-10 vol. \%) and accessory apatite, zircon, titanite, magnetite, ilmenite, monazite, leucoxene and epidote group minerals. Porphyritic granite from the Michałowice quarry contains K-feldspar phenocrysts filled with numerous thin, vein-like perthites and inclusions of plagioclase that are imbricated in places, as well as small inclusions of quartz and biotite. The plagioclase (An 0-39\%) is zoned and displays albite and Carlsbad twinning (Figure 7B), [18]. The plagioclase is sericitized, epidotized and myrmekitic. Biotite occurs as automorphic hexagonal plates that in places are partly chloritized, as is the rare hornblende. The biotite contains inclusions of zircon and apatite. Granite sample C13 is characterized by a uniform matrix with grain size of up to $2 \mathrm{~mm}$, with larger hypautomorphic white and beige feldspar phenocrysts $(5-20 \mathrm{~mm})$ and automorphic quartz grains (Figure 7C). Plagioclase (An 10-15\%) forms myrmekite intercalations with quartz or is locally grow on potassium feldspar, in places replacing it. The plagioclase is sericitized and kaolinitized to 
varying degrees, and biotite is chloritized, with the appearance of the characteristic sagenite grid. Muscovite appears in the small aggregates, locally. Accessory minerals include zircon, monazite, titanite, magnetite leucoxene and apatite.
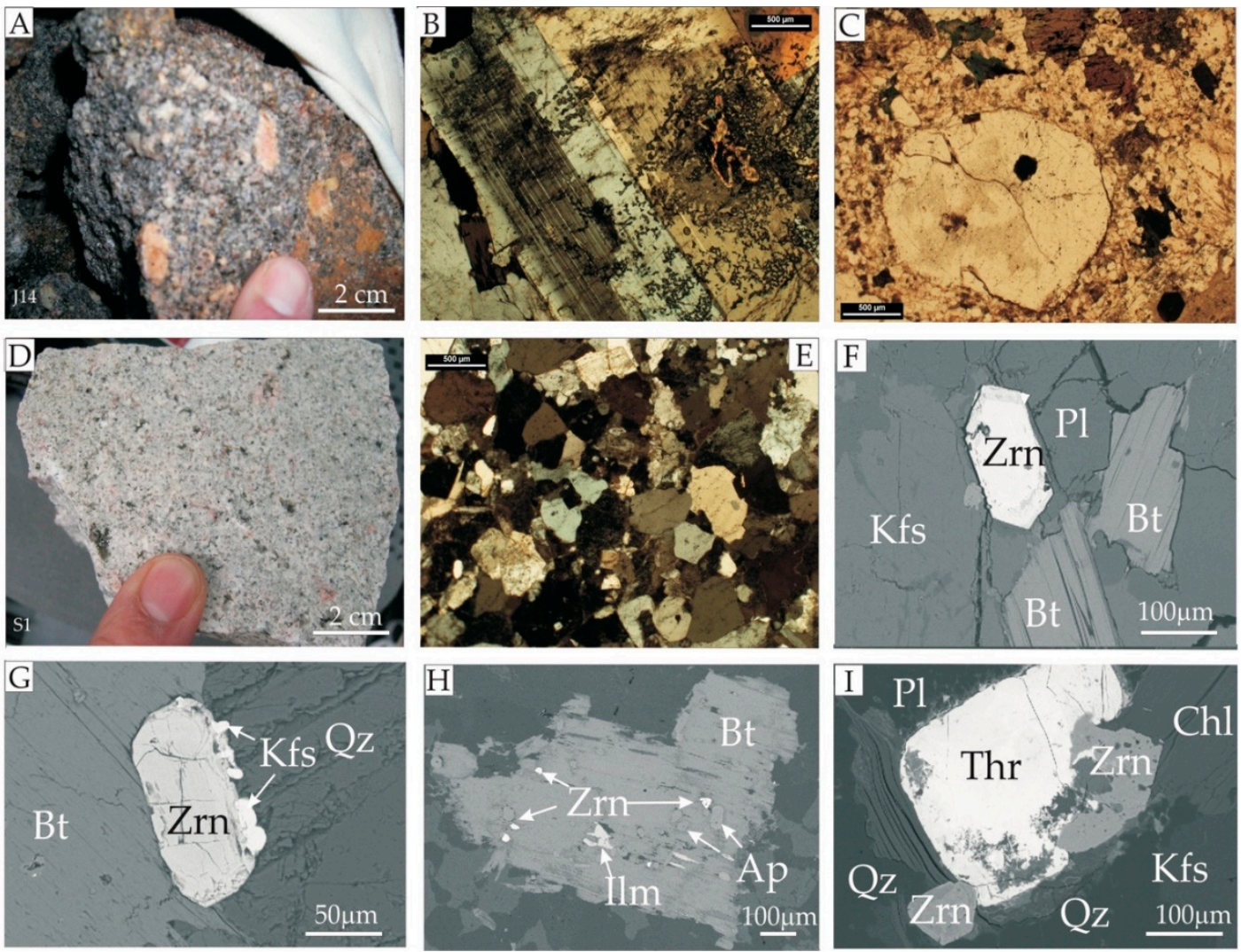

Figure 7. Photographs and photomicrographs of the studied igneous rocks from the KP and its eastern metamorphic cover (the Eastern Karkonosze). (A-C) coarse-grained porphyritic monzogranite ("central granite"); (A) sample J14 from the area of the Miedzianka polymetallic (-U) deposit; (B) Big crystal of twin K-feldspar. 2N (crossed nicols). Sample M12 from the Michałowice quarry; (C) phenocryst of quartz surrounded by sericite replacing plagioclase. Transmitted light, $1 \mathrm{~N}$ (uncrossed nicols), Sample C13 from the area of the Czarnów polymetallic deposit; (D) fine-grained equigranular monzogranite ("ridge granite") Sample S1 from the Szklarska Poręba Huta quarry, photograph and photomicrograph (E) in transmitted light, 2N; (F) Sample J15 from the area of the Miedzianka polymetallic (-U) deposit; zircon (Zrn) crystal in association with K-feldspar (Kfs), plagioclase (Pl) and biotite (Bt); (G) Sample J15; K-feldspar (Kfs) overgrowth on zircon crystallized between biotite (Bt) and quartz (Qz); (H) Sample C13; fine crystals of zircon (Zrn), apatite (Ap) and ilmenite (Ilm) in biotite (Bt); (I) Sample C13; zircon crystals intergrowing with thorite (Thr) surrounded by chlorite (Chl), quartz (Qz), K-feldspar (Kfs) and plagioclase $(\mathrm{Pl})$.

The second type of granite sampled (J15, S1), equigranular monzogranite, is pale in color, (almost white) and fine-grained, with characteristic rounded quartz grains (up to $5 \mathrm{~mm}$ ), plagioclase, alkaline feldspar, muscovite and scarce biotite (Figure 7D,E). Fine-grained varieties of this granite have an aplitic appearance with feldspar phenocrysts (perthite intercalated with plagioclase). The granite contains K-feldspar (18-36 vol. \%), plagioclase (25-35 vol. \%), quartz (30-42 vol. \%), biotite (1-6 vol. \%), small amounts of muscovite ( $<0.1$ vol. \%) and accessory apatite, zircon, allanite, titanite, epidote, magnetite, ilmenite, monazite and thorite (Figure 7G-I), [18].

On Harker diagrams both granite facies display similar geochemical trends for the major oxides. They show a systematic decrease in $\mathrm{Al}_{2} \mathrm{O}_{3}, \mathrm{Na}_{2} \mathrm{O}, \mathrm{P}_{2} \mathrm{O}_{5}, \mathrm{TiO}_{2}, \mathrm{Fe}_{2} \mathrm{O}_{3}, \mathrm{CaO}$ and $\mathrm{MgO}$, as well as in $\mathrm{Sr}, \mathrm{V}$ and $\mathrm{Ba}$ with increasing $\mathrm{SiO}_{2}[17,18]$. Only $\mathrm{K}_{2} \mathrm{O}$ correlates positively with $\mathrm{SiO}_{2}$. $\mathrm{For}_{\mathrm{SiO}}$ contents from 
69.3 to 77.9 wt. $\%, \mathrm{~K}_{2} \mathrm{O}$ and $\mathrm{Na}_{2} \mathrm{O}$ concentrations range from 2.9 to $6.1 \mathrm{wt} . \%$, and from 2.8 to $4.2 \mathrm{wt.} \%$, respectively (Figure 8). The very homogeneous equigranular granite is $\mathrm{SiO}_{2}$-rich (73.01-78.50 wt.\%) with low $\mathrm{Mg}$-number (atomic $\mathrm{Mg} /(\mathrm{Mg}+\mathrm{Fe})$ ) values of 0.11-0.38, [17]. The equigranular granite is mostly peraluminous, with $\mathrm{A} / \mathrm{CNK}\left(\mathrm{Al}_{2} \mathrm{O}_{3} /\left(\mathrm{CaO}+\mathrm{Na}_{2} \mathrm{O}+\mathrm{K}_{2} \mathrm{O}\right)\right)$ ranging from 0.98 to 1.14 [16]. The porphyritic granite has the same characteristics, except that it ranges towards slightly lower $\mathrm{SiO}_{2}$ contents and higher Mg-number (0.47). Some samples are significantly poorer in $\mathrm{K}_{2} \mathrm{O}$ than the equigranular granite (Figure 8 ).

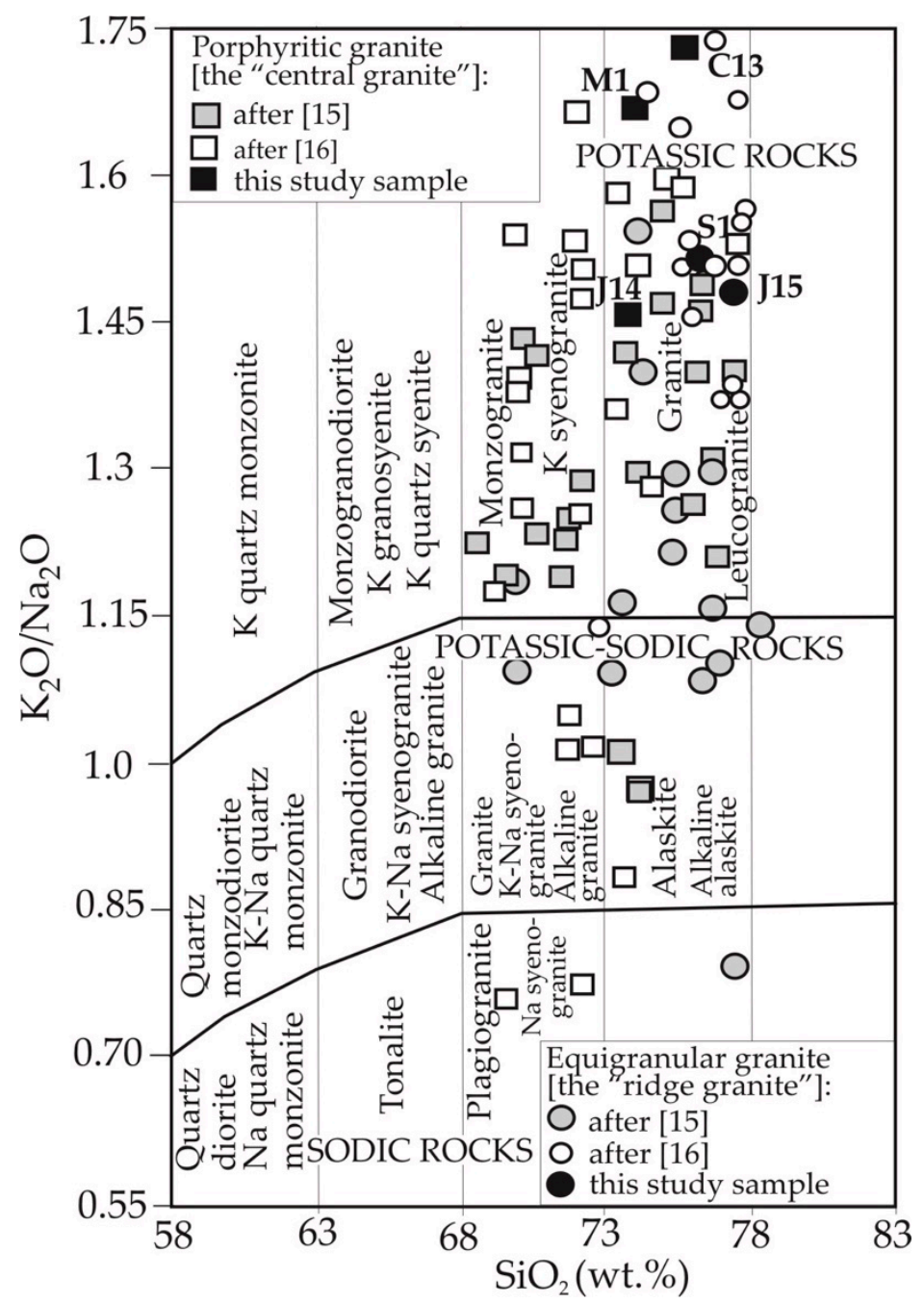

Figure 8. Classification of porphyritic (square) and equigranular (circle) granites from the Karkonosze Pluton on the diagram $\mathrm{Na}_{2} \mathrm{O} / \mathrm{K}_{2} \mathrm{O}$ vs. $\mathrm{SiO}_{2}$; Data after $[16,17]$ and this study.

The sample of mineralized rhyolite (M2) comes from mining waste in the central part of the deposit field at Miedzianka (Figure 3A). The rhyolite has a mottled beige-grey color with a random or massive texture and a partly porous or aphanite crystalline structure. It consists of a fine-grained quartz-feldspar matrix, in which there are phenocrysts of white and pink feldspar (1-3 mm), and less commonly quartz and black biotite (Figure 9A). Biotite occurs as plates 1-2 mm diameter. The feldspars are orthoclase and Na-oligoclase (An $10-30 \%$ vol. \%). The rock mode is quartz (30\%), K-feldspar $(20 \%)$, plagioclase $(40 \%)$ and muscovite and biotite $(10 \%)$. Zircon, titanite and magnetite occur as accessories. The feldspar is sericitized. Pyrite is common as poikilitic hypautomorphic grains $(\leq 1-2 \mathrm{~mm})$ and larger granular aggregates together with $\mathrm{Cu}$ sulfides (chalcopyrite, bornite) and arsenopyrite (Figure 9B-E). The pyrite contains inclusions of other sulfides, as well as rock-forming 
minerals (biotite, chlorite) and minor minerals such as $\mathrm{Nb}$-bearing rutile (c.a. $4 \mathrm{wt} \% \mathrm{Nb}_{2} \mathrm{O}_{5}$ ), allanite, thorite and probably fergusonite. Arsenopyrite, chalcopyrite, sphalerite, and galena are present as fine-grained disseminations or aggregates. Small fine tablets of molybdenite in chlorite are also present (Figure 9F). Locally, REE carriers with complex mineral compositions (Figure 9G-I) appear in pegmatitic quartz granophyric intergrowths with $\mathrm{K}$-feldspar. EPMA analyses of the unnamed REE minerals (probably from group of Nioboaeschynite-( $\mathrm{Y}$ indicate significant contents of $\mathrm{Y}_{2} \mathrm{O}_{3}(14-30 \mathrm{wt}$. \%), $\mathrm{Nb}_{2} \mathrm{O}_{5}$ (max. 15.9 wt.\%), REEO (total 9-21wt.\%), $\mathrm{ThO}_{2}$ and $\mathrm{UO}_{3}$ (max. 8 wt.\%) and $\mathrm{WO}_{3}$ (3-18 wt.\%).
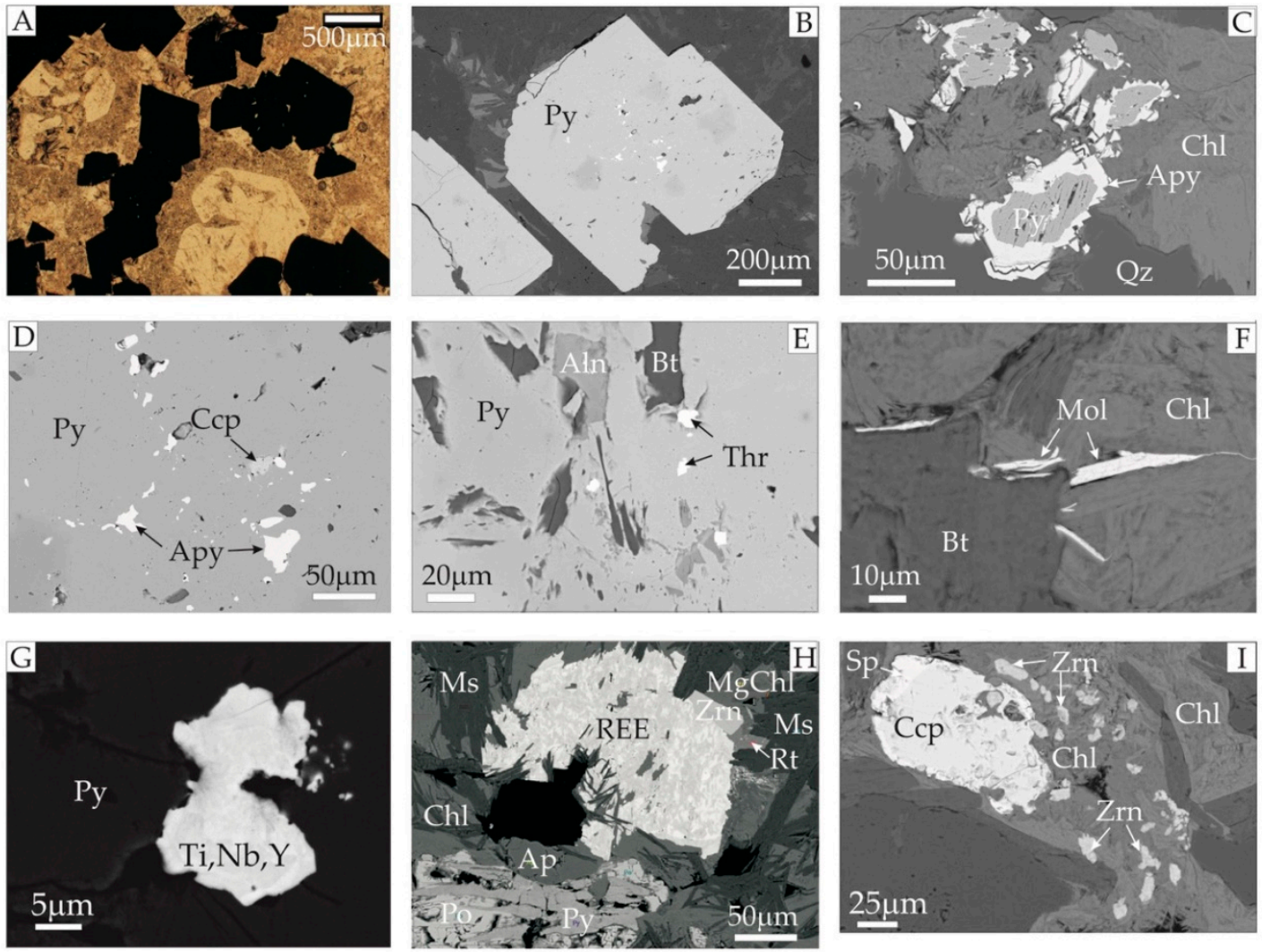

Figure 9. Ore mineralization from rhyolite porphyry Sample M2 from the central ore field in the abandoned Miedzianka Cu(-U) deposit. (A) Rhyolite porphyry from the Miedzianka deposit with disseminated pyrite (black) and quartz phenocrysts in a quartz-feldspar matrix. $1 \mathrm{~N}$, transmitted light; (B) automorphic pyrite (Py) crystals with fine inclusions of sulfides (white); (C) arsenopyrite (Apy) replacing medium-size pyrite; (D) numerous fine inclusions of arsenopyrite (Apy) and chalcopyrite (Ccp); (E) fine inclusions of thorite (Thr), allanite (Aln) and biotite (Bt) hosted by pyrite (Py); (F) fine blades of molybdenite between biotite $(\mathrm{Bt})$ and chlorite $(\mathrm{Chl})$ crystals; $(\mathrm{G})$ very fine inclusion of an unidentified Ti, Nb, Y and REE-bearing mineral hosted by pyrite (Py); $(\mathbf{H})$ aggregate of REE-bearing unidentified minerals associated with chlorite and other minerals within coarse-grained pegmatite intergrowths hosted by rhyolite porphyry. Abbreviations: REE-unidentified REE-bearing minerals with contents of $\mathrm{Y}, \mathrm{Ti}, \mathrm{Nb}, \mathrm{W}$, Th and $\mathrm{U}$ oxides; $\mathrm{Ap}$ - apatite; $\mathrm{Chl}$ and $\mathrm{MgChl}-\mathrm{Mg}$ enriched chlorite; Ms-muscovite; Zrn—zircon; Rt—rutile. (I) chalcopyrite (Ccp) with sphalerite (Sp) associated with chlorite (Chl) and numerous fine-grained zircons (Zrn).

The chemical composition of the rhyolite porphyry (WD-XRF) is $74.2 \% \mathrm{SiO}_{2}, 3.26 \% \mathrm{~K}_{2} \mathrm{O}$, and $7.2 \%$ $\mathrm{Fe}_{2} \mathrm{O}_{3}$, plus low $(<0.15 \%) \mathrm{Na}_{2} \mathrm{O}, \mathrm{CaO}, \mathrm{MgO}$ and $\mathrm{TiO}_{2}$. In addition, the rock contains elevated $\mathrm{Cu}$ (355 ppm), Sn (108 ppm), Zn (88 ppm), and As (56 ppm). 


\section{Analytical Methods}

Approximately $3-5 \mathrm{~kg}$ of each rock sample were crushed and the heavy mineral fraction $(<250 \mu \mathrm{m})$ separated using standard low-contamination heavy liquid and magnetic separation procedures. Zircon grains were handpicked, mounted in epoxy resin with reference zircon SL13 (U = 238 ppm) and TEMORA $2\left({ }^{206} \mathrm{~Pb}^{*} / 238 \mathrm{U}=0.06683\right)$, sectioned, polished, imaged (SEM and optical microscope), cleaned and Au coated for SHRIMP analysis at the Research School of Earth Sciences, ANU, using well-established procedures $[78,79]$. The data were processed by linear time interpolation $[78,79]$ using PRAWN and LEAD software written by T. Ireland, and where necessary corrected for high-U matrix effects [80]. Concordia plots were prepared using ISOPLOT software written by K. Ludwig [81], and weighted mean ages calculated from ${ }^{206} \mathrm{~Pb} / 238 \mathrm{U}$, corrected for late Carboniferous common $\mathrm{Pb}$ using ${ }^{207} \mathrm{~Pb}$. Individual analyses are plotted with $1 \sigma$ error ellipses, and uncertainties in the weighted mean ages, which include the uncertainty in the standardization $(0.3 \%)$, are quoted at the $95 \%$ confidence level ( $t \sigma$ where ' $t$ ' is Student's $t$ ).

Detailed mineralogical and petrographic examinations of samples of six igneous rocks and ore mineralization from the sampled sites, together with photo-micrographic documentation, were carried out on a NIKON ECLIPSE LV100 POL microscope containing NIS-Elements software (Version 3.22). Selected ore minerals were investigated using a LEO-1430 (Obekochen, Germany,) electron microscope (ZEISS) with an EDS (energy-dispersive X-ray spectroscope) detector, then analyzed using a Cameca SX-100 EPMA (Gennevilliers, Cedex, France) equipped with five wavelength dispersive X-ray spectrometers (WDS). The operating parameters were: accelerating voltage $15 \mathrm{kV}$, beam current $20 \mathrm{nA}$, and focused beam ( $<1 \mu \mathrm{m}$ diameter); acquisition times at the peak position $20 \mathrm{~s}$, at the background position $10 \mathrm{~s}$, and carbon sputtering; international (commercial) standards used were from the SPI-53 set from SPI and from the sulf-16 set from P\&H. CAMECA software and procedures were used for a final correction of all measured elements.

Chemical analyses of the six igneous rock samples were carried out by wavelength dispersive X-ray fluorescence spectrometry (WD-XRF) using a Philips PW-2400 spectrometer at the Chemical Laboratory of the Polish Geological Institute-National Research Institute in Warsaw. Trace elements (As, Ba, Bi, Cd, Ce, Co, Cr, Cu, Ga, Hf, La, Mo, Nb, Ni, Pb, Rb, Sn, Sr, Th, U, V, Y, Zn, and Zr) were determined in pressed powder samples and major elements $\left(\mathrm{SiO}_{2}, \mathrm{TiO}_{2}, \mathrm{Al}_{2} \mathrm{O}_{3}, \mathrm{Fe}_{2} \mathrm{O}_{3}, \mathrm{MnO}, \mathrm{MgO}\right.$, $\mathrm{CaO}, \mathrm{Na}_{2} \mathrm{O}, \mathrm{K}_{2} \mathrm{O}, \mathrm{P}_{2} \mathrm{O}_{5}, \mathrm{SO}_{3}, \mathrm{Cl}$, and $\mathrm{F}$ ) in fused samples. The conditions of WD-XRF measurements for major oxides and trace elements were as follows: X-ray tube with Rh anode (3 kW); analyzing crystals LiF 200, PE, Ge, and PX1; collimators $0.15 \mathrm{~mm}$ and $0.30 \mathrm{~mm}$; and detector scintillation counter, flow proportional counter $(\mathrm{Ar} / \mathrm{CH} 4)$, and Xe-sealed proportional counter.

\section{Results of the Zircon Dating}

\subsection{Porphyritic Granite (Samples M12, J14, and C13)}

\subsubsection{Michałowice Quarry (Sample M12)}

The selected zircon grains from Michałowice porphyritic monzogranite sample M12 were medium to large (50-200 $\mu \mathrm{m}$ diameter), clear to slightly turbid, colorless to pale pink, euhedral crystals with simple crystal form and aspect ratios of 2-7:1. They had numerous fine mineral inclusions, and many were finely fractured. Concentric zoning was visible in many grains in transmitted light. Cathodoluminescence (CL) imaging showed mostly simple concentric or banded oscillatory zoning in all grains, most grains consisting of zircon with relatively strong luminescence surrounded by finely zoned, weakly luminescent zircon (Figure 10A). About $25 \%$ of the grains contained a core with zoning discordant relative to that in the rim. The aim was to date the emplacement of the granite, so only simply zoned zircon near the margins or terminations of the grains was analyzed. The $U$ contents of the analyzed zircon were consistently moderately high $(\sim 1080-2525 \mathrm{ppm})$ and $\mathrm{Th} / \mathrm{U}$ was relatively uniform (most 0.18-0.34), (Appendix C). Except for one analysis (2.1), common Pb contents were low. 
The U-Pb isotopic compositions were all concordant within analytical uncertainty but the radiogenic ${ }^{206} \mathrm{~Pb} /{ }^{238} \mathrm{U}$ ratios were scattered (Figure $10 \mathrm{~B}$ ). The analysis with high common Pb had very low ${ }^{206} \mathrm{~Pb} /{ }^{238} \mathrm{U}$, consistent with $\mathrm{Pb}$ migration both out of and into the analyzed spot. Omitting that analysis left a cluster of 12 analyses still with a small but significant scatter (MSWD (Mean Squared Weighted Deviation $)=2.5$ ). The scatter was due to two analyses $(6.1,12.1)$ that were low, probably also due to radiogenic $\mathrm{Pb}$ loss. Omitting those left 10 analyses equal within analytical uncertainty (MSWD $=1.5)$, giving a weighted mean ${ }^{206} \mathrm{~Pb} /{ }^{238} \mathrm{U}$ age of $308.4 \pm 2.3 \mathrm{Ma}$ (95\% c.1.), (Figure 10B).
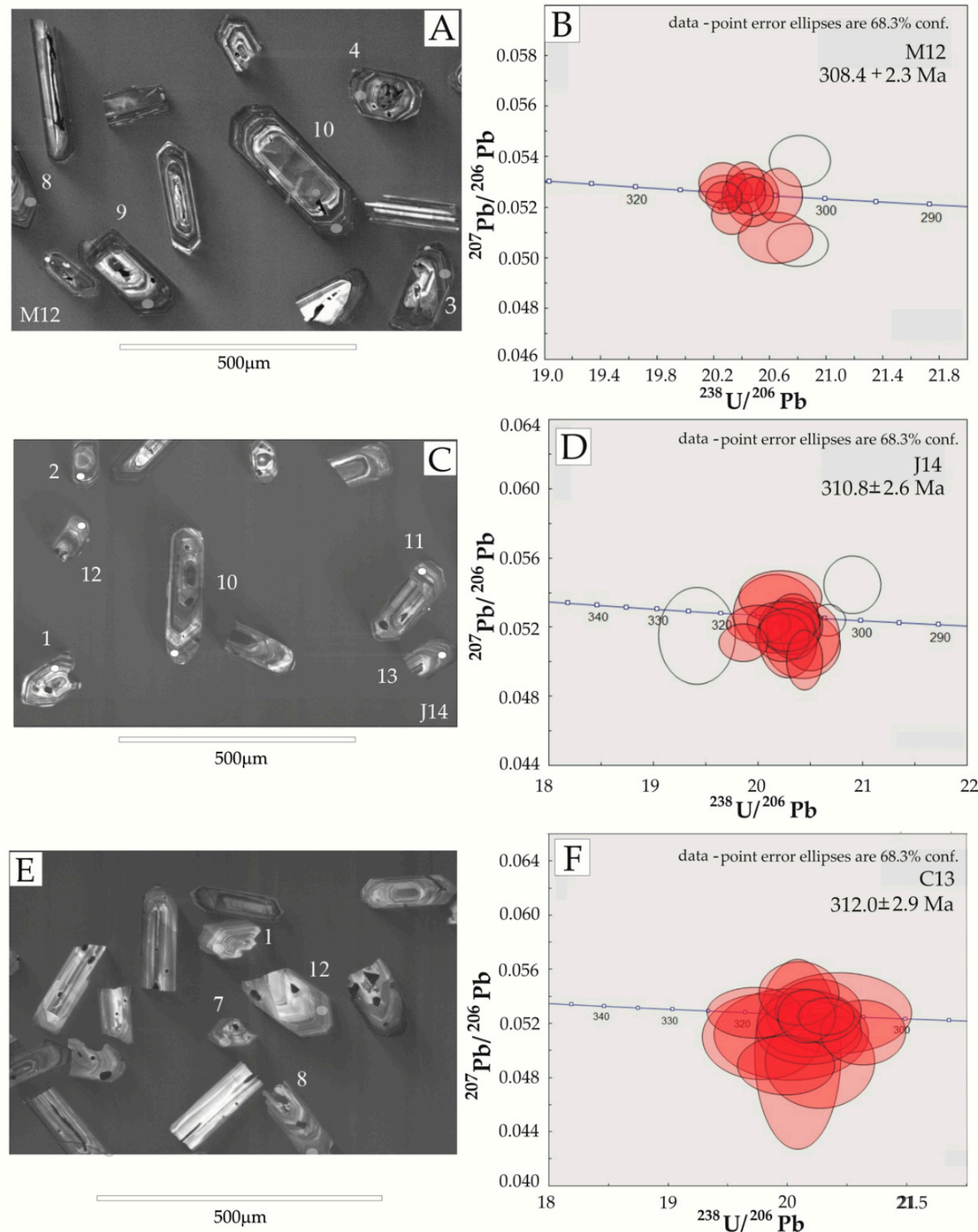

Figure 10. Cathodoluminescence images of selected zircon grains (ellipses show analysis locations) and concordia diagrams showing SHRIMP zircon U-Pb analyses (open symbols-analyses not included in the age calculations) of porphyritic granite from the $\mathrm{KP}$, corrected for common $\mathrm{Pb}$ using ${ }^{204} \mathrm{~Pb}$; (A,B) Sample M12, from the Michałowice quarry; (C,D) Sample J14, from Janowice Wielkie near the area of the Miedzianka deposit; (E,F) Sample C13, from the area of the Czarnów As-polymetallic deposit. 


\subsubsection{Janowice Wielkie (Sample J14)}

The selected zircon grains from porphyritic monzogranite sample J14 were medium to large ( 100-200 $\mu$ m diameter), clear to slightly turbid, colorless to pale pink, euhedral crystals with simple crystal forms and aspect ratios of 2-7:1. The longest grains lacked terminations due to breakage, presumably during rock crushing. They contained numerous acicular inclusions (apatite?) and were mostly finely fractured. Concentric growth zoning was visible in some grains in transmitted light. $\mathrm{CL}$ imaging showed that most grains were relatively weakly luminescent, consisting of a center commonly with poorly developed zoning surrounded by zircon with fine concentric oscillatory zoning (Figure 10C). The center of some grains was occupied by a large non-luminescent inclusion. Cores with zoning discordant to the rims were rare. U-Pb analyses of simply zoned zircon from 16 grains showed mostly moderate $\mathrm{U}$ contents ( $\sim 400-1000 \mathrm{ppm})$, a range of $\mathrm{Th} / \mathrm{U}(0.30-0.92)$ and consistently low common $\mathrm{Pb}$ contents. All the isotopic analyses were concordant within analytical uncertainty (Figure 10D) but there was a range in radiogenic ${ }^{206} \mathrm{~Pb} /{ }^{238} \mathrm{U}(\mathrm{MSWD}=3.4)$. One analysis $(1.1)$, perhaps partially sampling a core, was much higher than the rest. Omitting it reduced the scatter but did not eliminate it (MSWD $=2.6)$. The scatter was due to two low analyses $(5.1,9.1)$ showing Pb loss, one of which had a high $U$ content. Omitting those left 13 analyses with equal ${ }^{206} \mathrm{~Pb} /{ }^{238} \mathrm{U}$ within analytical uncertainty (MSWD $=1.0)$, giving a weighted mean ${ }^{206} \mathrm{~Pb} /{ }^{238} \mathrm{U}$ age of $310.8 \pm 2.6 \mathrm{Ma}(95 \%$ c.l.) (Figure 10D).

\subsubsection{Czarnów Au-As-Polymetallic Deposit (Sample C13)}

The selected zircon grains from Czarnów porphyritic granite sample $\mathrm{C} 13$ were medium to large ( 100-200 $\mu \mathrm{m}$ diameter), clear, colorless to pale pink, euhedral crystals with simple crystal forms and aspect ratios of 2-5:1. They contained both mineral and fluid inclusions, many grains having axial cavities. Fractures were rare. Some grains were partly discolored by rusty iron staining. CL imaging showed that most of the grains had fine concentric or banded oscillatory zoning (Figure 10E). About 10\% of the grains contained a core with zoning discordant to the rim. Analyses of 13 grains, avoiding cores, showed moderate $\mathrm{U}$ contents (most $200-560 \mathrm{ppm}$ ) and Th/U ratios (0.28-0.72). The U-Pb isotopic analyses, only one of which had a moderate common $\mathrm{Pb}$ content, formed a single concordant cluster with no significant scatter in radiogenic ${ }^{206} \mathrm{~Pb} /{ }^{238} \mathrm{U}(\mathrm{MSWD}=0.9)$. The weighted mean ${ }^{206} \mathrm{~Pb} /{ }^{238} \mathrm{U}$ age from 14 analyses was $312.0 \pm 2.9 \mathrm{Ma}(95 \%$ c.l.), (Figure 10F).

\subsection{Equigranular Granite (Samples S1, and J15)}

\subsubsection{Szklarska Poręba Huta Granite Quarry (Sample S1)}

The selected zircon grains from equigranular granite sample S1 collected at the Szklarska Poręa Huta quarry were small to medium ( 50-150 $\mu$ m diameter), clear to quite turbid, pale pink to brownish, euhedral to subhedral crystals with mostly simple crystal forms and low aspect ratios of 1-3:1. Most grains were finely fractured and contained few inclusions. Rarely, concentric zoning was visible in transmitted light. There was a large contrast in CL. About $40 \%$ of the grains consisted of a brightly luminescent center with indistinct to weak zoning surrounded by very weakly luminescent zircon with simple, fine concentric oscillatory zoning (Figure 11A). The remaining grains consisted entirely of very weakly luminescent zircon with simple fine zoning. Texturally distinct cores were rare. Sixteen U-Pb analyses, mostly of weakly luminescent, finely zoned zircon, showed consistently high U contents (1070-3335 ppm), a narrow range of Th/U (0.19-0.48), and many high common $\mathrm{Pb}$ contents, up to $435 \mathrm{ppb}{ }^{204} \mathrm{~Pb}$. The isotopic compositions were nevertheless concordant within analytical uncertainty (Figure 11B), but scattered in radiogenic ${ }^{206} \mathrm{~Pb} /{ }^{238} \mathrm{U}(\mathrm{MSWD}=22)$. Much of the scatter was due to one very low analysis affected by $\mathrm{Pb}$ loss (10.1), omitting which reduced the MSWD to 13.1. Three other analyses $(3.1,5.1,12.1)$, all with moderate to high common Pb contents, fell below the main group. Omitting those, assuming radiogenic $\mathrm{Pb}$ loss, reduced the MSWD to 4.3 , but significant scatter still remained. This could be eliminated in two ways: by omitting high and low analyses from the group 
in order of the size of their deviation from the mean, or by taking only those analyses with low common $\mathrm{Pb}$ contents, all of which gave relatively high ${ }^{206} \mathrm{~Pb} /{ }^{238} \mathrm{U}$. The first process resulted in the omission of one additional low analysis and three high ones, leaving nine analyses equal within analytical uncertainty, giving a weighted mean age $301.9 \pm 2.5 \mathrm{Ma}$ (95\% c.1.). The second process left only five analyses equal within analytical uncertainty (MSWD $=0.96$ ), resulting in a weighted mean age of $306.9 \pm 3.0 \mathrm{Ma}$ (95\% c.1.). Despite the lower number of analyses retained in the latter case, that result is preferred because the presence of common $\mathrm{Pb}$ is indicative of open system behavior and $\mathrm{Pb}$ isotopic exchange, which commonly results in reduced radiogenic ${ }^{206} \mathrm{~Pb} /{ }^{238} \mathrm{U}$. The best age estimate is therefore that based on those grains in which the isotopic system is most likely to have remained closed, $306.9 \pm 3.0$ Ma (95\% c.l.), (Figure 11B).
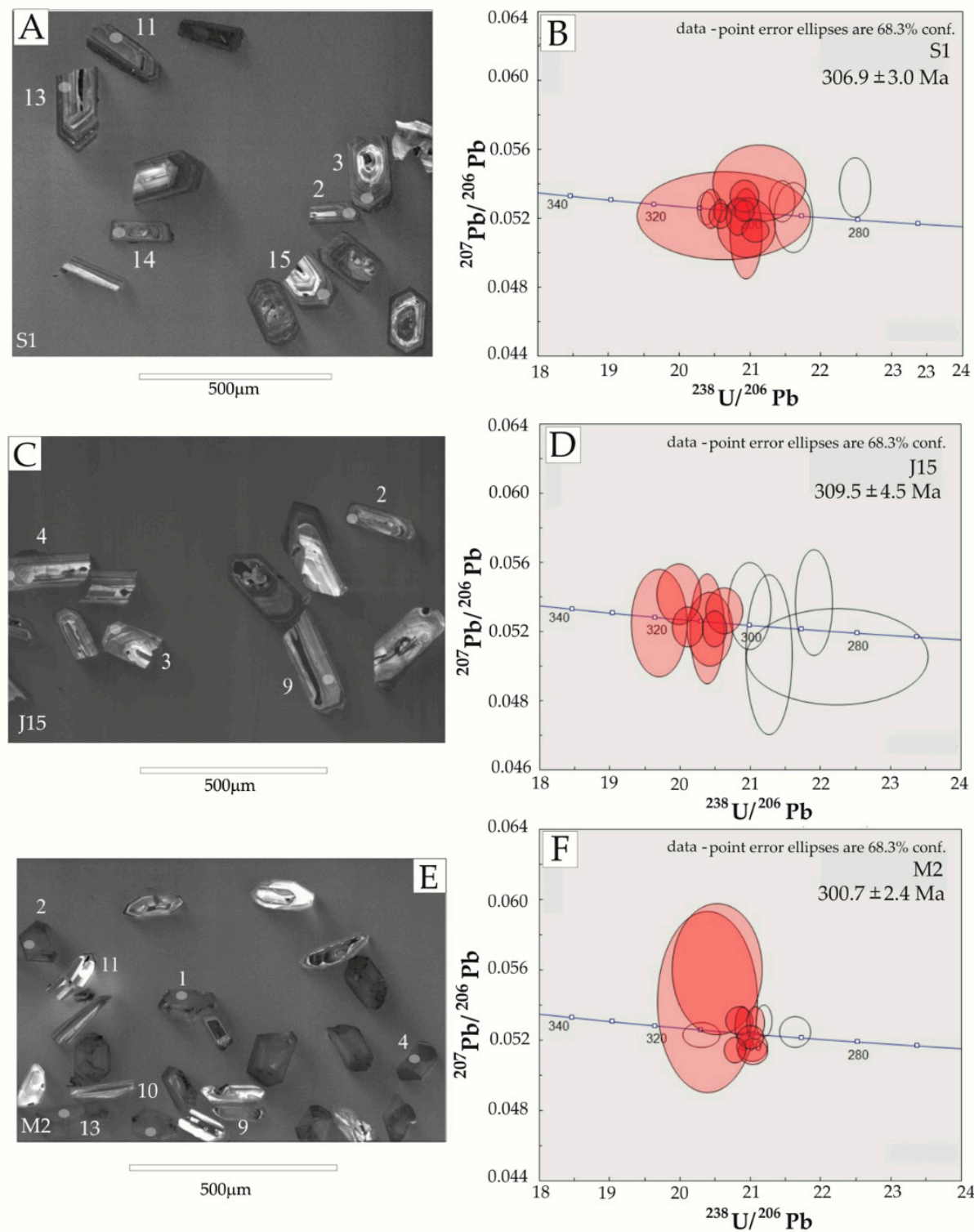

Figure 11. Cathodoluminescence images of selected zircon grains (ellipses show analysis locations) and concordia diagrams showing SHRIMP zircon U-Pb analyses (open symbols-analyses not included in the age calculations) of igneous rocks from the area of the KP and its eastern metamorphic cover. $(\mathbf{A}, \mathbf{B})$ equigranular granite, Sample S1, from the Szklarska Poręba Huta granite quarry; (C,D) equigranular granite, Sample J15, from the area of the Miedzianka deposit; $(\mathbf{E}, \mathbf{F})$ rhyolite porphyry, Sample M2, from the Miedzianka $\mathrm{Cu}(-\mathrm{U})$ deposit. 


\subsubsection{Janowice Wielkie (Sample J15)}

The selected zircon grains from equigranular granite sample J15 were medium to large ( $100-200 \mu \mathrm{m}$ diameter), clear to quite turbid, colorless to pale pink, euhedral to subhedral crystals with mostly simple crystal forms and aspect ratios of 2-5:1 (Figure 11C). They contained numerous acicular inclusions, were finely fractured, and some concentric zoning was visible in transmitted light. A few grains showed signs of weak partial dissolution. CL imaging showed a range of textures. Some grains $(\sim 20 \%)$ had fine concentric oscillatory zoning throughout. In most grains the zoning in the center was indistinct or irregular and associated with large, non-luminescent inclusions. The centers mostly had somewhat brighter luminescence than the weakly luminescent zoned zircon surrounding them. Twelve U-Pb analyses of mostly simply zoned zircon showed a wide range of moderate to high $\mathrm{U}$ contents ( $250-4950 \mathrm{ppm}$ ), a limited range of $\mathrm{Th} / \mathrm{U}$ (most $0.28-0.43$ ) and, with one exception (5.1, the highest- $\mathrm{U}$ grain), low common $\mathrm{Pb}$ contents. The U-Pb isotopic analyses were all concordant within analytical uncertainty (Figure 11D), but with a large range in radiogenic ${ }^{206} \mathrm{~Pb} /{ }^{238} \mathrm{U}$ (MSWD = 155). Much of the scatter was due to the grain with high $\mathrm{U}$ and high common $\mathrm{Pb}(5.1)$, which had very low ${ }^{206} \mathrm{~Pb} /{ }^{238} \mathrm{U}$. Omitting that analysis, assuming an open system, the MSWD fell to 11.4. Even omitting four other analyses $(4.1,6.12,7.1,11.1)$ that plotted significantly below the main group because of $\mathrm{Pb}$ loss did not eliminate the scatter entirely (MSWD $=2.5$ ), but there remained no other obvious outliers. Accepting that the remaining 7 analyzed spots are not the same isotopic composition within analytical uncertainty and probably isotopically disturbed, the weighted mean ${ }^{206} \mathrm{~Pb} /{ }^{238} \mathrm{U}$ age is $309.5 \pm 4.5 \mathrm{Ma}$ (95\% c.l.), the larger uncertainty reflecting the presence of excess scatter (Figure 11D).

\subsection{Rhyolite Porphyry (Sample M2)}

The mix of zircon types in the Miedzianka rhyolite porphyry sample M2 resembled that in the rhyolite porphyry from Wielisławka (sample W4, [82]), but with more fracturing. There were two zircon subpopulations: 1) stubby euhedral grains 20-100 $\mu \mathrm{m}$ diameter with low aspect ratios $(\leq 2: 1)$ and 2$)$ finer ( $\leq 50 \mu \mathrm{m}$ diameter) more elongate (aspect ratio 2-4:1) subhedral grains, some with more complex pyramidal terminations. CL imaging showed that the two zircon types had different zoning textures (Figure 11E). The stubby euhedral grains had very weak luminescence and broad sector zoning; the more elongate grains had stronger luminescence and a range of textures from fine concentric to broad banded oscillatory zoning. Several of the elongate grains had features indicative of partial recrystallization. Of the 14 grains analyzed, 10 were stubby and weakly luminescent, 4 were elongate with banded zoning. The two zircon types had contrasting $U$ contents $(\sim 1450-2100 \mathrm{ppm}$ in the stubby grains, $\sim 110-1250 \mathrm{ppm}$ in the elongate grains) and $\mathrm{Th} / \mathrm{U}(\sim 0.4-0.6$ and $\sim 0.35-0.88$, respectively). Isotopic analyses of all except two grains with high common $\mathrm{Pb}$ contents formed a near-concordant cluster at about $300 \mathrm{Ma}$ (Figure 11F), but there was nevertheless a significant range in radiogenic ${ }^{206} \mathrm{~Pb} /{ }^{238} \mathrm{U}(\mathrm{MSWD}=5.0$ ). The scatter was mainly due to the analyses of two stubby grains $(1.1,3.1)$, which had significantly lower and higher ${ }^{206} \mathrm{~Pb} /{ }^{238} \mathrm{U}$ respectively than the main group. Omitting those analyses reduced the scatter significantly but did not eliminate it (MSWD $=2.2$ ). That could only be done by also omitting one other low analysis (2.1). Doing so left nine analyses with equal radiogenic ${ }^{206} \mathrm{~Pb} /{ }^{238} \mathrm{U}$ within uncertainty (MSWD $=1.1$ ), giving a weighted mean age of $300.7 \pm 2.4 \mathrm{Ma}$ (95\% c.l.), (Figure 11F). Both types of zircon are the same age within analytical uncertainty.

\section{Discussion}

\section{1. $\mathrm{U}-\mathrm{Pb}$ Geochronology}

Zircon $\mathrm{U}-\mathrm{Pb}$ dating of five granitoids from the central region and eastern margin of the Variscan Karkonosze Pluton, and a rhyolite dyke cutting the metamorphosed cover sequence at the Miedzianka $\mathrm{Cu}-(\mathrm{U})$ deposit, yields ${ }^{206} \mathrm{~Pb} /{ }^{238} \mathrm{U}$ ages in the range from $312.0 \pm 2.9$ to $300.7 \pm 2.4 \mathrm{Ma}$ (Figure 12). All the igneous rocks investigated came from zones containing a variety of ore mineralization, 
the genesis of which was associated mainly with the development of pneumatolitic-hydrothermal and contact-metasomatic processes connected with magmatic evolution of the KP [31]. The oldest dated rocks were two monzogranite porphyries from the direct contact zone between the granitoids and mineral deposits at Czarnów (312.0 $\pm 2.9 \mathrm{Ma})$ and Miedzianka (310.8 $\pm 2.6 \mathrm{Ma})$. A third sample of coarse monzogranite porphyry from the granite quarry at Michałowice yielded ${ }^{206} \mathrm{~Pb} /{ }^{238} \mathrm{U}$ age of $308.4 \pm 2.3 \mathrm{Ma}$. The ages of equigranular monzogranite samples collected from the area close to the Miedzianka deposit and from the granite quarry at Szklarska Poręba Huta were $309.5 \pm 4.5$ and $306.9 \pm 3.0 \mathrm{Ma}$, respectively.

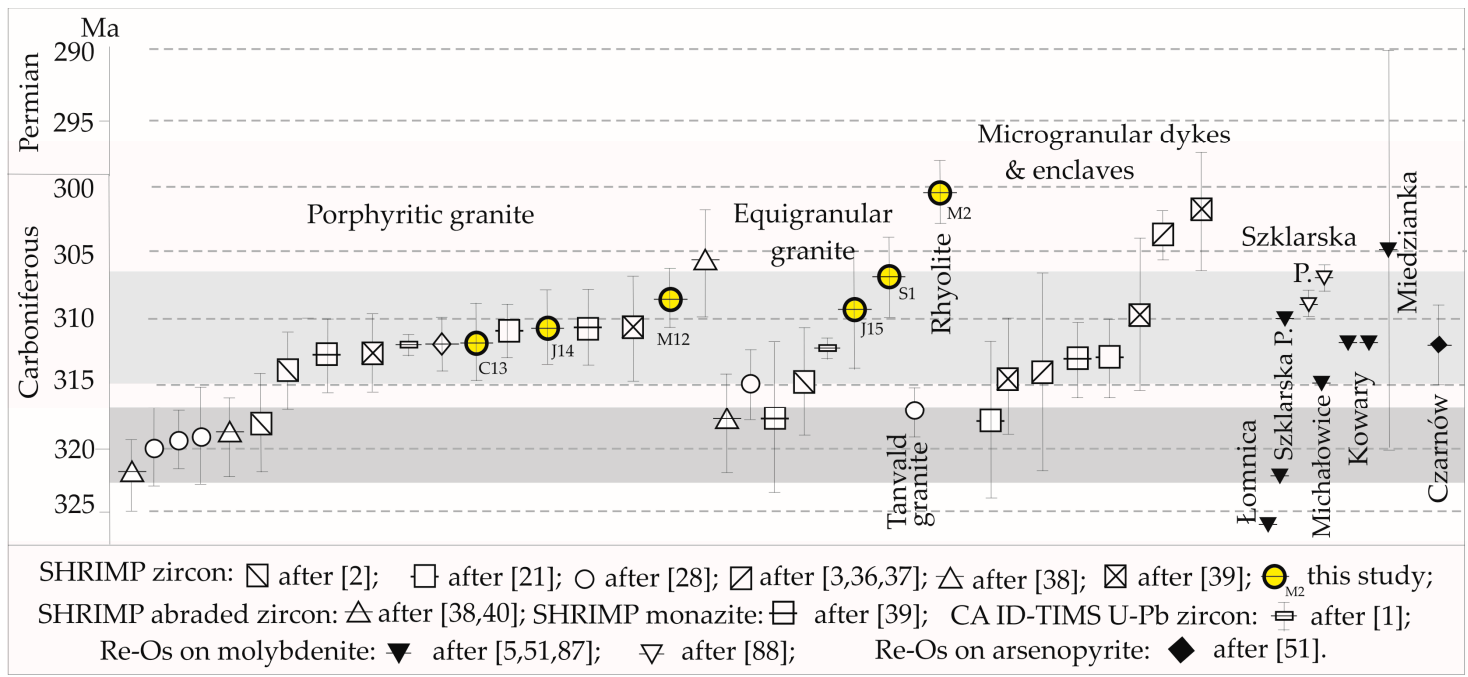

Figure 12. $\mathrm{U}-\mathrm{Pb}$ and $\mathrm{Re}-\mathrm{O}$ s isotopic geochronology of igneous rocks and sulfides from the $\mathrm{KP}$ and its eastern metamorphic cover.

All samples contained zircon with abnormally high $U$ and Th contents (Appendix C), a feature noted in several previous studies of zircon from the KP $[1,2,39,40]$. U contents of the analyzed zircon from the porphyritic monzogranite were up to $2525 \mathrm{ppm}$, from the equigranular monzogranite up to $4950 \mathrm{ppm}$, and from the rhyolite up to $2100 \mathrm{ppm}$. Those are underestimates of the maximum $\mathrm{U}$ contents in the zircon populations as the analyzed spots were carefully selected so as to avoid high- $U$ areas and minimize the effects of metamictization and hydrothermal alteration-Radiogenic $\mathrm{Pb}$ loss and high common $\mathrm{Pb}$. Such effects are one of the major difficulties in zircon dating the various phases of the KP [38], and result from the abnormally high $\mathrm{U}$ and Th contents of many of the KP granites (U 1-49 ppm, Th 8-54 ppm, Th/U 1-10) [16], and the postmagmatic hydrothermal activity that produced the small mineral deposits and numerous manifestations of uranium mineralization in the KP itself and in its immediate vicinity [16,31,47,63,64].

Most of the zircon $\mathrm{U}-\mathrm{Pb}$ ages previously reported from the two main rock types in the KP are in the range ca. 315-306 Ma (Figure 13). The range of results from the present study is similar, $312.0 \pm 2.9$ to $306.9 \pm 3.0 \mathrm{Ma}$ (Figure 12). Although this range is not significant given the analytical uncertainties, the fact that the age of the equigranular monzogranite from the Szklarska Poreba Huta quarry is at the younger end of the range is consistent with the field relationships between porphyritic and equigranular monzogranite at that site. There are several other sites where equigranular granite has intruded older porphyritic granite [24], although according to some petrological [17] and geochronological studies [39], the age relationship between those two main facies remains unresolved (Figure 13). 


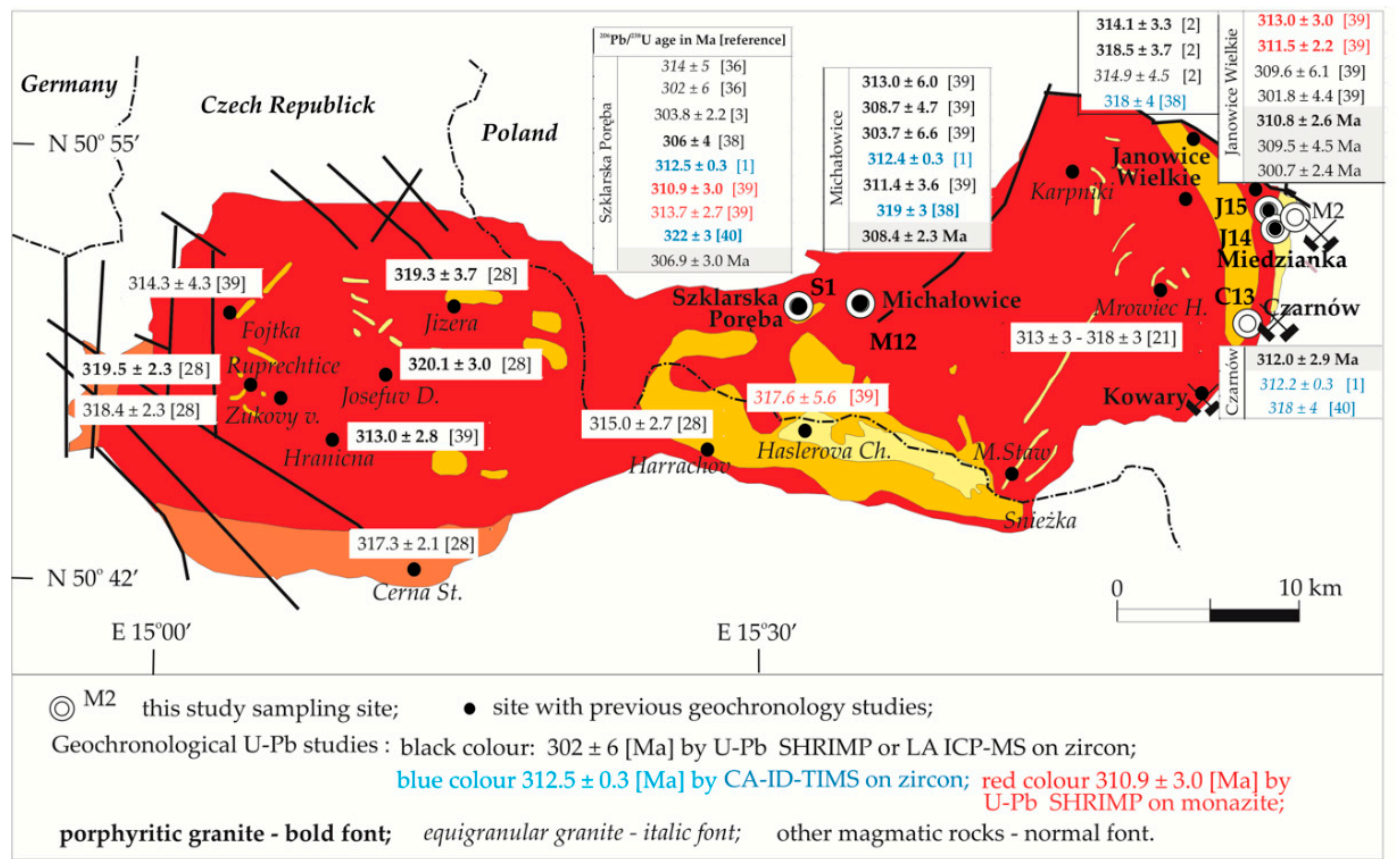

Figure 13. The location of the samples and the results of the U-Pb isotopic geochronology of igneous rocks from the KP and its eastern metamorphic cover.

The youngest result, $300.7 \pm 2.4 \mathrm{Ma}$, came from zircon from the rhyolite porphyry dyke cutting metamorphic rocks in the area of the Miedzianka deposit. This is similar to the zircon age previously measured on KP microgranular dykes, $303.8 \pm 2.2 \mathrm{Ma}$ [3], and is about 8.8 Ma younger than the weighted mean age for the five monzogranites dated for the present study. It is also similar to the age of magmatic-volcanic processes in the Intra-Sudetic Basin adjacent to the eastern KP. Regional Permo-Carboniferous extension in that within-plate basin was accompanied by extensive bimodal sub-volcanic and volcanic magmatism over the period $306 \pm 3$ Ma to $299 \pm 4$ Ma [82-85]. That volcanism was accompanied by hydrothermal activity responsible for base metal sulfide mineralization which, in several places in the Western Sudetes, and especially in the Eastern Karkonosze, fractured and overprinted earlier high-temperature ore mineralization (Mo-W-Sn-REE-Fe-Cu-As).

The zircon ${ }^{206} \mathrm{~Pb} /{ }^{238} \mathrm{U}$ age of $300.7 \pm 2.4 \mathrm{Ma}$ for rhyolite porphyry from the Miedzianka deposit also constrains the timing of tectonic movements along the major Intra Sudetic Fault Zone (ISF). If the rhyolite porphyry is syntectonic the U-Pb age is a minimum age constraint on shear zone activity. The dated rhyolite dyke strikes parallel to the ISF. It intruded after granite emplacement during regional movement along the ISF and the on lap of the Leszczyniec Unit (Figure 3A) [10]. At the end of the Carboniferous, the geotectonic setting of the central European Variscides changed from post-collisional to within-plate [12], accompanied by tectonic and volcanic activity. Relatively late sinistral movement along the ISF has cut off part of the contact aureole of the KP against the Kaczawa Complex to the NE (Figure 1), providing evidence that the movement post-dated the emplacement of the KP [86].

\subsection{Re-Os Geochronology of Ore Mineralization}

Comparison of the U-Pb data with Re-Os dating of sulfides (mainly molybdenites) from the same sites in the Karkonosze massif and in the Eastern Karkonosze $[5,6,87,88]$ (Figure 12) provides insights into the mineralization process. Comparison with the molybdenite data reveals both age similarities and small differences, recognizing that two different radiometric clocks, $\mathrm{U}-\mathrm{Pb}$ and $\mathrm{Re}-\mathrm{Os}$, are recording the timing of crystallization of two different minerals in a complex magmatic setting.

Dating of molybdenite from the Szklarska Poręba Huta (SPH) quarry identified two different age groups-older ( $323 \pm 1 \mathrm{Ma}$ ) and younger (310 \pm 1 to $307 \pm 2 \mathrm{Ma})[5,6,88]$. The younger results 
are consistent with our $\mathrm{U}-\mathrm{Pb}$ dating of equigranular monzogranite (306.9 $\pm 3.0 \mathrm{Ma})$, and also with all other $\mathrm{U}-\mathrm{Pb}$ dating of both types of monzogranite (porphyritic and equigranular) from the $\mathrm{SPH}$ quarry (ca. 314-304 Ma) [1,2,36-39]. The molybdenite occurs with other sulfides, sulfosalts, oxides and REE, Th and U minerals within coarse-grained pegmatite quartz-feldspar intergrowths in aplogranite (Figure 14A). Both types have low concentrations of Re (ca. 0.32 and 0.12 ppm, respectively), [6]. The molybdenite ages are consistent with our zircon ages, and also with previously determined $\mathrm{Rb}-\mathrm{Sr}$ ages of equigranular granite (310 $\pm 14 \mathrm{Ma}$ [32] and $309 \pm 3 \mathrm{Ma}$ [33]) and the Sm-Nd age of a porphyritic granite enclave from Mały Staw (309 $\pm 17 \mathrm{Ma}$ [25]). They are also consistent with a refined ${ }^{206} \mathrm{~Pb} /{ }^{238} \mathrm{U}$ age (306 $\pm 4 \mathrm{Ma}$ ) of zircon from the SPH porphyritic granite [1]. These Re-Os molybdenite ages from the Szklarska Poręba Huta quarry are comparable to molybdenite ages from quartz-feldspar veins in the Paszowice quarry, Strzegom-Sobótka Massif, Fore-Sudetic Block, $309 \pm 1$ to $304 \pm 1$ Ma [89]. The older molybdenite age $\left(323 \pm 1 \mathrm{Ma}, \mathrm{Re}=0.18 \mathrm{ppm}\right.$ with $\left.{ }^{187} \mathrm{Os}=0.6141 \mathrm{ppb}\right)$ has no equigranular monzogranite age equivalent, though a SIMS age of chemically treated zircon from the porphyritic granite is similar [38].
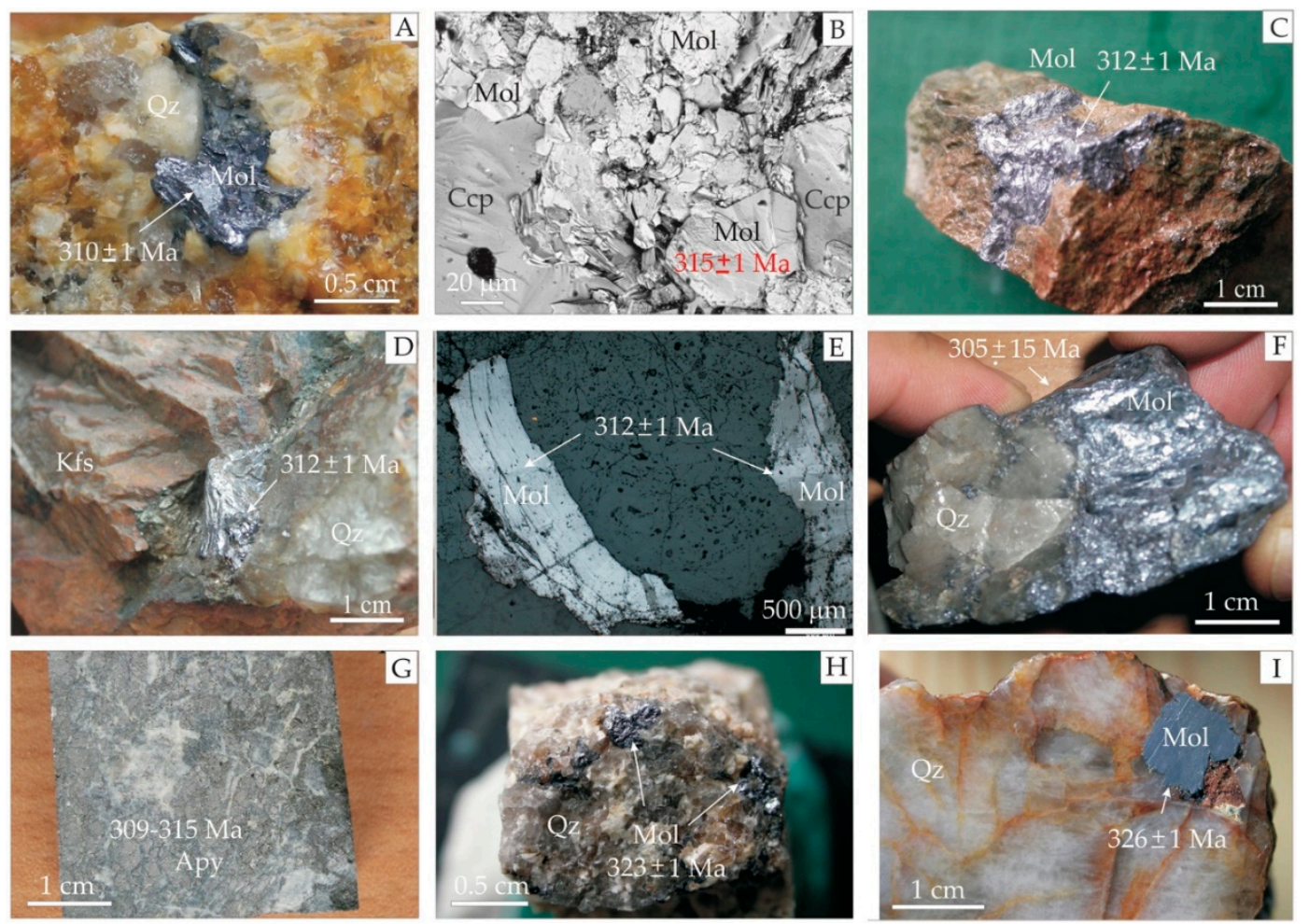

Figure 14. (A-I) Photographs of molybdenites and arsenopyrite from the Karkonosze Pluton and its eastern metamorphic cover with its Re-Os isotopic ages after [5,6,87]. (A) Molybdenite (Mol) plates disseminated in pegmatitic intergrowths of quartz $(\mathrm{Qz})$ and K-feldspar, Szklarska Poręba Huta granite quarry; (B) hexahedral molybdenite (Mol) plates in association with chalcopyrite (Ccp), abandoned Michałowice quarry. BSEI; (C) molybdenite (Mol) coat-like aggregate in skarn, abandoned Kowary Fe-U mine; (D) molybdenite (Mol) crystal aggregate hosted by quartz-K-feldspar rock, Kowary Fe-U mine; (E) fragment of sample from (D) macrophotography with molybdenite (Mol) as separate bladed crystals under reflected light; (F) molybdenite (Mol) crusty aggregates in quartz (Qz) vein, Miedzianka $\mathrm{Cu}$-(U) deposit; (G) massive Co-bearing arsenopyrite in (Apy) quartz vein, Czarnów As-polymetallic deposit; (H) fine molybdenite (Mol) crystals intergrown with vein quartz (Qz), Szklarska Poręba Huta granite quarry; $(\mathbf{I})$ molybdenite $(\mathrm{Mol})$ in fractured quartz $(\mathrm{Qz})$ vein with rusty Fe ochre along fractures, Łomnica Górna abandoned granite quarry.

At 315.0 \pm 1.0 Ma [5], molybdenite from a pegmatitic quartz-feldspar intergrowth in porphyritic monzogranite from the Michałowice quarry is about 7 Ma older than the zircon age of the monzogranite 
measured in this study $(308.4 \pm 2.3 \mathrm{Ma})$. Re and Os concentrations are $8.5 \mathrm{ppm}$ and $28 \mathrm{ppb}$. Molybdenite occurs as separate coarse-grained aggregates of hexagonal plates, accompanied by chalcopyrite, pyrite, wolframite, cassiterite, scheelite and arsenopyrite (Figure 14B) and minor superimposed galena, sphalerite, and $\mathrm{Au}$ - and U-mineralization [16]. Both ages are within uncertainty of previously reported $\mathrm{U}-\mathrm{Pb}$ zircon ages for porphyritic monzogranite from the Michałowice quarry (311.4 $\pm 3.6 \mathrm{Ma}$, [39] and $312.4 \pm 0.3 \mathrm{Ma}[2])$, but younger than the result obtained from chemically abraded zircon at $319 \pm 3 \mathrm{Ma}$ [38]. They are also within uncertainty of the U-Pb ages measured here on porphyritic and equigranular monzogranites from the area of the Miedzianka and Czarnów deposits, $312.0 \pm 2.9$ Ma to $309.5 \pm 4.5 \mathrm{Ma}$.

The Re-Os ages of molybdenite from deposits in the eastern cover of the KP are in the same range, especially those of two molybdenite samples from the Kowary Fe-U deposit. That deposit is located a few kilometers south of the Czarnów deposit along the contact with the KP. The two samples have Re contents of $22.4 \mathrm{ppm}$ and $2.97 \mathrm{ppm}$ with respective ${ }^{187} \mathrm{Os}$ contents of $73.4 \mathrm{ppb}$ and $9.7 \mathrm{ppb}$, and both yield the same age of $312.0 \pm 1.0 \mathrm{Ma}$ (Figure 14C-E). These ages are also close to a Re-Os age from molybdenite from Miedzianka and arsenopyrite from Czarnów. Molybdenite from Miedzianka occurs as tiny blades $(<0.5 \mathrm{~mm}$ ) which form an aggregate (up to $50 \mathrm{~mm}$ ) intergrown with quartz (Figure $14 \mathrm{~F}$ ). This gangue quartz may also contain K-feldspar and fine-grained pyrite. The concentrations of Re and Os in molybdenite from Miedzianka are very low (Re $0.22 \mathrm{ppm}$ and Os $0.5-0.7 \mathrm{ppb}$ ). Consequently, two very different ages were obtained, one which may be compromised and one with a larger than desired uncertainty (305 $\pm 15 \mathrm{Ma})$ [51].

A similar Re-Os age ( $312 \pm 3 \mathrm{Ma}$ ) has been measured on Co-bearing arsenopyrite (Figure 14G) from the contact-metasomatic and hydrothermal quartz/lode type As-polymetallic Czarnów deposit [51]. Only one of the five analyzed sulfides, however, had a high enough ${ }^{187} \mathrm{Re} /{ }^{188} \mathrm{Os}(>18,000)$ to calculate a reliable model age [51]. Ages calculated using a range of possible initial ${ }^{187} \mathrm{Os} /{ }^{188} \mathrm{Os}$ ratios show that the Re-Os age for this Low Level Highly Radiogenic (LLHR; [90]) massive arsenopyrite is almost certainly between 315 and $309 \mathrm{Ma}$. This result is in broad agreement with the previously published Re-Os isochron age of Co-rich arsenopyrite ( $317 \pm 17 \mathrm{Ma}$ ) from the Radzimowice Au-As-Cu deposit located directly to the north in the Kaczawa Mountains, and with the Re-Os age of LLHR Co-rich arsenopyrite from the Klecza-Radomice Au deposit (316.6 \pm 0.4 Ma) [91,92]. These were the first Re-Os ages for Co-As sulfide minerals, establishing the utility of Co-As-rich sulfides for Re-Os dating fifteen years ago. The ages of $\sim 315 \mathrm{Ma}$ are close to Re-Os molybdenite data (313-312 Ma) reported for the Fe-Cu-As Obři důl skarn mineralization from the exocontact of the Krkonoše-Jizera Plutonic Complex [93].

Some older molybdenite has been reported from the KP area, including samples from the Szklarska Poręba Huta and Łomnica Górna quarries. The older molybdenite from Szklarska Poręba occurs as rosette aggregates overgrowing vein quartz (Figure $14 \mathrm{H})$. Concentrations of $\operatorname{Re}(0.18 \mathrm{ppm})$ and ${ }^{187} \mathrm{Os}$ $(0.6 \mathrm{ppb})$ yielded an age of $323.0 \pm 1.0 \mathrm{Ma}$ [51]. Molybdenite from Łomnica yielded a slightly older Re-Os age of $326.0 \pm 1.0 \mathrm{Ma}$ from the KP (Figure 14I) [87]. Significantly, both these molybdenites were hosted by quartz veins and occur in the form of different size aggregates associated with $\mathrm{Fe}$ and $\mathrm{Cu}$ sulfides, ilmenite and Bi minerals. The molybdenite from Łomnica, however, formed somewhat larger rosette aggregates and had higher concentrations of Re (36 ppm). These older molybdenites from the KP correlate with molybdenite ages obtained for $\mathrm{Sn}-\mathrm{W}-(\mathrm{Li})$ deposits in the Erzgebirge metallogenetic province which indicate the predominance of one and/or multiple short-time mineralization events taking place between $\sim 319$ and $323 \mathrm{Ma}$ [94].

The formation of the few older molybdenites may have been associated with an early episode of pneumatolitic-hydrothermal processes in the KP, which is also supported by ${ }^{40} \mathrm{Ar} /{ }^{39} \mathrm{Ar}(320 \pm 2 \mathrm{Ma}$ [34] $)$ and $\mathrm{Rb}-\mathrm{Sr}$ (328 $\pm 12 \mathrm{Ma}$ [25]) dates, as well as the chemically abraded zircon age of one porphyritic granite (322 $\pm 3 \mathrm{Ma}$ [1]). They are, however, about $10 \mathrm{Ma}$ older than $\mathrm{U}-\mathrm{Pb}$ zircon ages measured in the present study on porphyritic and equigranular monzogranite host rocks from the same areas. The few older zircon ${ }^{206} \mathrm{~Pb} /{ }^{238} \mathrm{U}$ ages, e.g., the CA zircon date from Michałowice (319 $\pm 3 \mathrm{Ma}$ [1]), the zircon $\mathrm{U}-\mathrm{Pb}$ dates from the Szklarska Poręba Huta $(322 \pm 3 \mathrm{Ma})$ and the southern part of the KP (320.1 \pm 3.0 to 
$319.5 \pm 2.3 \mathrm{Ma}$ ) [28], would benefit from further examination. Pneumatolitic and hydrothermal activity in the KP may have lasted for $>30$ million years, but additional Re-Os and U-Pb dating is required before the full duration is realized.

\section{Conclusions}

1. SHRIMP zircon U-Pb dating of five igneous rocks from the Karkonosze Pluton yields ${ }^{206} \mathrm{~Pb} /{ }^{238} \mathrm{U}$ ages in the range $312 \pm 3$ to $308 \pm 2 \mathrm{Ma}$, identical within uncertainty with U-Pb results from the Variscan younger magmatic event in the Sudetes. The U-Pb ages are also consistent with Re-Os ages ( $315 \pm 1$ to $307 \pm 2 \mathrm{Ma}$ ) for the younger generation of molybdenites from pegmatites and veins hosted by the Karkonosze Pluton, as well as from polymetallic deposits (Kowary, Miedzianka and Czarnów) located along its contact with metamorphic cover in the Eastern Karkonosze. Molybdenite belongs to the Mo-W-Sn-Fe-Cu-As-REE-Nb-Y-U-Th mineral paragenesis related to precipitation from pneumatolitic and hydrothermal fluids of magmatic origin that are likely to have been circulating, and in some places post-dating that process by a few millions of years.

2. The younger ${ }^{206} \mathrm{~Pb} /{ }^{238} \mathrm{U}$ age of $300.7 \pm 2.4 \mathrm{Ma}$ obtained from a rhyolite dyke which cuts the metamorphic rocks in the $\mathrm{Cu}-(\mathrm{U})$ Miedzianka deposit correlates well with the series of sub-volcanic-volcanic processes in the nearby Intra Sudetic Basin and with regional tectonic movements on the Intra-Sudetic Fault after the Karkonosze Pluton was emplaced. The appearance of rhyolite dykes is evidence for the development of sub-volcanic processes that were responsible for development of younger (ca. $301 \mathrm{Ma}$ ) Cu-polymetallic ore mineralization in the study area. This stage of ore mineralization, known from the eastern metamorphic cover of the KP, was superimposed on older, high-temperature Fe-Cu-As-Sn mineralization (molybdenite age $312 \pm 1$ Ma, Kowary deposit; Co-arsenopyrite age 312-307 Ma, Czarnów deposit). This older ore mineralization was fractured, brecciated and overprinted by a younger generation of base metal sulfides, with visible $\mathrm{Au}$ (remobilized from the primary sulfides) and Bi-Ag-Te-Se sulfosalt mineralization. The U-Pb age of the rhyolite dyke from the Miedzianka deposit also puts a constraint of ca. $301 \mathrm{Ma}$ on the timing of tectonic movements along major suture and strike slip shear zones and hence the formation of terrane boundaries, and of the transitions between various tectonic regimes within the eastern segment of the central European Variscides.

3. Previously reported U-Pb ages in the range $325 \pm 2$ to $320 \pm 1$ Ma from the Karkonosze Pluton were not confirmed by our research. Additionally, older molybdenite Re-Os ages (325 \pm 1 and $323 \pm 3 \mathrm{Ma}$ ) could be reconciled with the younger zircon $\mathrm{U}-\mathrm{Pb}$ ages of their igneous host rocks. It should be emphasized, however, that the strong development of pneumatolitic-hydrothermal processes in the KP, the metamictization of zircon caused by its high $\mathrm{U}$ and Th contents, and the likely presence of inherited zircon can impact the accuracy of zircon U-Pb dates.

Author Contributions: Field work, S.Z.M., J.W.; SIMS analyses S.Z.M., I.S.W.; data analysis, S.Z.M., I.S.W., H.J.S.; ore microscopy, S.Z.M., J.W.; Figures, S.Z.M., I.S.W.; writing—original draft preparation, S.Z.M.; writing一review and editing S.Z.M., I.S.W., H.J.S. All authors have read and agreed to the published version of the manuscript.

Funding: The final editorial work was financially supported by the Polish Geological Institute-National Research Institute statutory funds (Project No. 62.9012.2011.00 for S.M). The AIRIE Program receives no financial support for its personnel or analytical facility at Colorado State University. Some financial support for the SHRIMP analyses was provided by the Research School of Earth Sciences, Australian National University.

Conflicts of Interest: The authors declare no conflict of interest. 


\section{Appendix A}

Table A1. Summary of igneous rock and sulfide dating from the Karkonosze Pluton and its Eastern Metamorphic Cover.

\begin{tabular}{|c|c|c|c|c|}
\hline Area & Lithology or Mineral/Site & Age [Ma] & Method & Author \\
\hline \multirow{20}{*}{ Szklarska Poręba } & equigranular granite & $328 \pm 12$ & \multirow{3}{*}{$\mathrm{Rb}-\mathrm{Sr}$ (w. rock) } & [32] \\
\hline & porphyritic granite & $328 \pm 12$ & & [33] \\
\hline & leucogranite & $310 \pm 15$ & & [25] \\
\hline & \multirow[b]{2}{*}{ equigranular granite } & $314 \pm 5$ & \multirow[b]{2}{*}{ U-Pb SHRIMP on Zrn } & \multirow[b]{2}{*}[36]{} \\
\hline & & $302 \pm 6$ & & \\
\hline & microgranular enclave & $303.8 \pm 2.2$ & U-Pb SHRIMP on CA Zrn & [3] \\
\hline & \multirow{3}{*}{ porphyritic granite } & $306 \pm 4$ & U/Pb SIMS, untreated Zrn & [38] \\
\hline & & $312.5 \pm 0.3$ & CA-ID-TIMS on Zrn & [1] \\
\hline & & $310.9 \pm 3.0$ & \multirow[b]{2}{*}{ U-Pb SHRIMP on mnz } & \multirow[b]{2}{*}{ [39] } \\
\hline & hybrid granitoids & $313.7 \pm 2.7$ & & \\
\hline & porphyritic granite & $322 \pm 3$ & U-Pb SHRIMP CA Zrn & [40] \\
\hline & equigranular granite & $306.9 \pm 3.0$ & U-Pb SHRIMP on Zrn & $\begin{array}{l}\text { This } \\
\text { study }\end{array}$ \\
\hline & \multirow{4}{*}{ molybdenite } & $310 \pm 1$ & \multirow{4}{*}{ Re-Os on Mol } & [51] \\
\hline & & $323 \pm 1$ & & {$[5,86]$} \\
\hline & & $307.4 \pm 2.4$ & & \multirow{2}{*}{ [87] } \\
\hline & & $308.9 \pm 2.1$ & & \\
\hline & \multirow{4}{*}{ porphyritic granite } & $329 \pm 17 ; 324 \pm 11$ & $\mathrm{Rb}-\mathrm{Sr}$ (w. rock) & [33] \\
\hline & & $313.0 \pm 6.0$ & \multirow{3}{*}{ U-Pb SHRIMP on Zrn } & \multirow{3}{*}{ [39] } \\
\hline & & $308.7 \pm 4.7$ & & \\
\hline & & $303.7 \pm 6.6$ & & \\
\hline \multirow{5}{*}{ Michałowice } & porphyritic granite & $312.4 \pm 0.3$ & CA-ID-TIMS on Zrn & [1] \\
\hline & porphyritic granite & $311.4 \pm 3.6$ & U-Pb SHRIMP on Zrn & [39] \\
\hline & porphyritic granite & $319 \pm 3$ & U-Pb SHRIMP CA Zrn & {$[38,40]$} \\
\hline & porphyritic granite & $308.4 \pm 2.3$ & U-Pb SHRIMP on Zrn & $\begin{array}{l}\text { This } \\
\text { study }\end{array}$ \\
\hline & molybdenite & $315 \pm 1$ & \multirow[b]{2}{*}{ Re-Os on Mol } & \multirow{2}{*}{ [86] } \\
\hline \multirow{6}{*}{ Łomnica Górna } & molybdenite & $326 \pm 1$ & & \\
\hline & porphyritic granite/"Fajka" & $314.1 \pm 3.3$ & \multirow{3}{*}{ U-Pb SHRIMP on Zrn } & \multirow{3}{*}{ [2] } \\
\hline & porphyritic granite/Radomierz & $318.5 \pm 3.7$ & & \\
\hline & equigranular granite & $314.9 \pm 4.5$ & & \\
\hline & magmatic enclave/E part of KP & $318 \pm 4$ & CA-ID-TIMS on Zrn & [38] \\
\hline & porphyritic granite/Piec crag & $313.0 \pm 3.0$ & & \multirow{4}{*}{ [39] } \\
\hline \multirow{7}{*}{ Janowice Wielkie } & porphyritic granite/Piec crag & $311.5 \pm 2.2$ & U-Pb SHRIMP on Mnz & \\
\hline & composite dyke/Karpniki & $309.6 \pm 6.1$ & \multirow{5}{*}{ U-Pb SHRIMP on Zrn } & \\
\hline & $\begin{array}{c}\text { microgranular } \\
\text { enclave/Mrowiec Hill }\end{array}$ & $301.8 \pm 4.4$ & & \\
\hline & porphyritic granite & $310.8 \pm 2.6 \mathrm{Ma}$ & & \multirow{3}{*}{ This study } \\
\hline & equigranular granite & $309.5 \pm 4.5 \mathrm{Ma}$ & & \\
\hline & rhyolite porphyry & $300.7 \pm 2.4 \mathrm{Ma}$ & & \\
\hline & $\begin{array}{l}\text { molybdenite/Miedzianka Cu } \\
\text { deposit }\end{array}$ & $305 \pm 15$ & Re-Os on Mol & [51] \\
\hline
\end{tabular}


Table A1. Cont.

\begin{tabular}{|c|c|c|c|c|}
\hline Area & Lithology or Mineral/Site & Age [Ma] & Method & Author \\
\hline $\begin{array}{c}\text { Karpacz-Janowice dyke } \\
\text { swarm }\end{array}$ & microgranodiorite & $313 \pm 3-318 \pm 3$ & \multirow{2}{*}{ U-Pb SHRIMP on Zrn } & [21] \\
\hline \multirow{2}{*}{ Czarnów } & porphyritic granite & $312.0 \pm 2.9 \mathrm{Ma}$ & & $\begin{array}{l}\text { This } \\
\text { study }\end{array}$ \\
\hline & arsenopyrite/As deposit & ca. 315 & Re-Os on Apy & [6] \\
\hline Kowary & $\begin{array}{c}\text { molybdenite/Kowary Fe-U } \\
\text { deposit }\end{array}$ & $312 \pm 1 ; 312 \pm 1$ & Re-Os on Mol & {$[6,51]$} \\
\hline \multirow{3}{*}{ Maływ Staw } & \multirow{3}{*}{ equigranular granite } & $309 \pm 3$ & $\mathrm{Rb}-\mathrm{Sr}$ (w. rock) & [33] \\
\hline & & $312.2 \pm 0.3$ & CA-ID-TIMS on Zrn & [1] \\
\hline & & $318 \pm 4$ & U-Pb SHRIMP CA Zrn & [40] \\
\hline \multirow{3}{*}{ Liberec type/Czech R. } & porphyritic monzogranite & $304 \pm 14$ & $\mathrm{~Pb} / \mathrm{Pb}$ evaporation $\mathrm{Zrn}$ & [35] \\
\hline & equigranular granite & $315 \pm 2$ & ${ }^{40} \mathrm{Ar} /{ }^{39} \mathrm{Ar}$ on $\mathrm{Msc}$ & \multirow{2}{*}[34]{} \\
\hline & $\begin{array}{l}\text { porphyritic granite Liberec } \\
\text { type }\end{array}$ & $320 \pm 2$ & ${ }^{40} \mathrm{Ar} /{ }^{39} \mathrm{Ar}$ on Bt & \\
\hline Cerna Studnice/Czech R. & Tanvald granite & $317.3 \pm 2.1$ & \multirow{6}{*}{ LA ICP-MS U-Pb on Zrn } & \multirow{6}{*}{ [28] } \\
\hline Ruprechtice quarry/Czech R. & $\begin{array}{c}\text { porphyritic granite Liberec } \\
\text { type }\end{array}$ & $319.5 \pm 2.3$ & & \\
\hline Josefuv Dul/Czech R. & \multirow{2}{*}{ porphyritic granite Jizera type } & $320.1 \pm 3.0$ & & \\
\hline Jizera summit/Czech R. & & $319.3 \pm 3.7$ & & \\
\hline Zukovy vrch/Czech R. & granodiorite/Fojtka & $318.4 \pm 2.3$ & & \\
\hline Harrachov/Czech R. & Harrachov granite type & $315.0 \pm 2.7$ & & \\
\hline Hranicna quarry/Czech R. & porphyritic granite & $313.0 \pm 2.8$ & \multirow{2}{*}{ U-Pb SHRIMP on Zrn } & \multirow{3}{*}[39]{} \\
\hline Fojtka/Czech R. & hybrid granitoids & $314.3 \pm 4.3$ & & \\
\hline Hašlerova Hata/Czech R. & $\begin{array}{l}\text { equigranular granite } \\
\text { Harrachov type }\end{array}$ & $317.6 \pm 5.6$ & U-Pb SHRIMP on Mnz & \\
\hline
\end{tabular}

Abbreviation: Apy—arsenopyrite; Bt—biotite; Mnz—monazite; Zrn—zircon; Mol—molybdenite.

\section{Appendix B}

Table A2. Description of igneous rock samples used for SHRIMP zircon U-Pb studies.

\begin{tabular}{|c|c|c|c|c|c|c|c|}
\hline Locality/Sample & Lithology & Texture & $\begin{array}{c}\text { Main } \\
\text { Composition }\end{array}$ & $\begin{array}{l}\text { Accessory } \\
\text { Minerals }\end{array}$ & $\begin{array}{c}\text { Ore } \\
\text { Minerals }\end{array}$ & Alteration & $\begin{array}{l}\text { Geographic } \\
\text { Co-Ordinates }\end{array}$ \\
\hline $\begin{array}{l}\text { Michałowice } \\
\text { quarry/M12 }\end{array}$ & & $\begin{array}{l}\text { coarse- and } \\
\text { medium-grained } \\
\text { porphyritic } \\
\text { with rose color } \\
\text { K-feldspar up } \\
3 \mathrm{~cm} \text { in size }\end{array}$ & $\begin{array}{l}\text { Qz, Mc, Pl, } \\
\text { Chl, Bt, Ser }\end{array}$ & $\begin{array}{l}\text { Zrn, Mnz, } \\
\text { Ap, Xtm, } \\
\text { Ep, REE } \\
\text { and } \\
\text { U-minerals }\end{array}$ & $\begin{array}{l}\text { Mag, Ilm, } \\
\text { Ti-Mag, } \\
\text { Ttn, Sch, } \\
\text { Cst, Wol, } \\
\text { Py, Lx }\end{array}$ & $\begin{array}{l}\text { K-feldspar } \\
\text { alteration: } \\
\text { sericitization, } \\
\text { perthitization, } \\
\text { chloritization } \\
\text { of biotite; } \\
\text { silicification } \\
\text { and } \\
\text { prehnitization }\end{array}$ & $\begin{array}{l}50^{\circ} 50^{\prime} 23^{\prime \prime} \mathrm{N} \\
15^{\circ} 34^{\prime} 05^{\prime \prime} \mathrm{E}\end{array}$ \\
\hline $\begin{array}{c}\text { Janowice } \\
\text { Wielkie/J14; }\end{array}$ & $\begin{array}{l}\text { monzogranite } \\
\text { "central" type }\end{array}$ & $\begin{array}{l}\text { medium- and } \\
\text { coarse-grained } \\
\text { porphyritic }\end{array}$ & $\begin{array}{c}\text { Qz, Pl, Kfs, } \\
\text { Mc, Bt, Ser, } \\
\text { Chl }\end{array}$ & $\mathrm{Zrn}, \mathrm{Ap}$ & $\begin{array}{l}\text { Ilm, Mag, } \\
\text { Rt, Ttn, Py }\end{array}$ & $\begin{array}{l}\text { K-feldspar } \\
\text { alteration: } \\
\text { sericitization, } \\
\text { pertitization, } \\
\text { chloritization } \\
\text { of biotite; } \\
\text { carbonatization, } \\
\text { myrmekitization }\end{array}$ & $\begin{array}{l}50^{\circ} 52^{\prime} 12^{\prime \prime} \mathrm{N} \\
15^{\circ} 55^{\prime} 36^{\prime \prime} \mathrm{E}\end{array}$ \\
\hline Czarnów/C13 & & $\begin{array}{l}\text { medium- } \\
\text { grained } \\
\text { porphyritic, } \\
\text { grey-brown }\end{array}$ & $\begin{array}{l}\mathrm{Qz}, \mathrm{Pl}, \mathrm{Kfs}, \\
\mathrm{Bt}, \mathrm{Ms}, \mathrm{Chl}\end{array}$ & Zrn, Ep & $\begin{array}{l}\text { Ilm, Rt, Py, } \\
\text { Ttn, Mag, } \\
\text { Lx }\end{array}$ & $\begin{array}{l}\text { K-feldspar } \\
\text { alteration: } \\
\text { sericitization, } \\
\text { perthitization, } \\
\text { chloritization } \\
\quad \text { of biotite; } \\
\text { carbonatization, } \\
\text { myrmekitization, } \\
\text { kaolinitization }\end{array}$ & $\begin{array}{l}50^{\circ} 48^{\prime} 35^{\prime \prime} \mathrm{N} \\
15^{\circ} 54^{\prime} 33^{\prime \prime} \mathrm{E}\end{array}$ \\
\hline
\end{tabular}


Table A2. Cont.

\begin{tabular}{|c|c|c|c|c|c|c|c|}
\hline Locality/Sample & Lithology & Texture & $\begin{array}{c}\text { Main } \\
\text { Composition }\end{array}$ & $\begin{array}{l}\text { Accessory } \\
\text { Minerals }\end{array}$ & $\begin{array}{c}\text { Ore } \\
\text { Minerals }\end{array}$ & Alteration & $\begin{array}{l}\text { Geographic } \\
\text { Co-Ordinates }\end{array}$ \\
\hline $\begin{array}{c}\text { Szklarska } \\
\text { Poręba Huta } \\
\text { quarry/S1 }\end{array}$ & \multirow{2}{*}{$\begin{array}{l}\text { monzogranite } \\
\text { "equigranular" } \\
\text { type }\end{array}$} & $\begin{array}{l}\text { fine-grained, } \\
\text { massive }\end{array}$ & $\begin{array}{c}\text { Qz, Mc, Pl, } \\
\text { Ms, Bt, } \\
\text { Chl, Ser, } \\
\text { Sch, Prh }\end{array}$ & $\begin{array}{l}\text { Zrn, Ep, } \\
\text { Ap, Aln, } \\
\text { Mnz }\end{array}$ & $\begin{array}{l}\text { Mol, Py, } \\
\text { Ilm, Ttn, } \\
\text { Mag }\end{array}$ & $\begin{array}{l}\text { K-feldspar } \\
\text { alteration: } \\
\text { sericitization, } \\
\text { perthitization, } \\
\text { chloritization } \\
\text { of biotite; } \\
\text { quartz and } \\
\text { prehnite } \\
\text { veinlets }\end{array}$ & $\begin{array}{l}50^{\circ} 49^{\prime} 39^{\prime \prime} \mathrm{N} \\
15^{\circ} 29^{\prime} 39^{\prime \prime} \mathrm{E}\end{array}$ \\
\hline $\begin{array}{c}\text { Janowice } \\
\text { Wielkie/J15 }\end{array}$ & & $\begin{array}{l}\text { fine-grained, } \\
\text { massive }\end{array}$ & $\begin{array}{c}\mathrm{Qz}, \mathrm{Pl}, \mathrm{Bt}, \\
\mathrm{Mc}\end{array}$ & $\begin{array}{l}\text { Zrn, Mnz, } \\
\text { Ep, Ap }\end{array}$ & Mag & $\begin{array}{l}\text { K-feldspar } \\
\text { alteration: } \\
\text { sericitization, } \\
\text { perthitization, } \\
\text { chloritization } \\
\text { of biotite; } \\
\text { quartz and } \\
\text { prehnite } \\
\text { veinlets }\end{array}$ & $\begin{array}{l}50^{\circ} 52^{\prime} 49^{\prime \prime} \mathrm{N} \\
15^{\circ} 55^{\prime} 45^{\prime \prime} \mathrm{E}\end{array}$ \\
\hline $\begin{array}{l}\text { Miedzianka } \\
\text { deposit/M2 }\end{array}$ & $\begin{array}{l}\text { rhyolite } \\
\text { porphyry }\end{array}$ & $\begin{array}{l}\text { fine-grained, } \\
\text { porphyritic, } \\
\text { massive }\end{array}$ & $\begin{array}{c}\text { Qz, Kfs, Pl, } \\
\text { Bt, Ms, } \\
\text { Chl, } \\
\text { Mg-Chl }\end{array}$ & $\begin{array}{l}\mathrm{Zrn}, \mathrm{REE} \\
\text { minerals }\end{array}$ & $\begin{array}{l}\text { Py, Ccp, } \\
\text { Bn, Sp, } \\
\text { Apy, Gn, } \\
\text { Ttn, Mag }\end{array}$ & $\begin{array}{l}\text { K-feldspar } \\
\text { alteration: } \\
\text { sericitization, } \\
\text { perthitization, } \\
\text { chloritization } \\
\text { of biotite }\end{array}$ & $\begin{array}{l}50^{\circ} 52^{\prime} 21^{\prime \prime} \mathrm{N} \\
15^{\circ} 56^{\prime} 35^{\prime \prime} \mathrm{E}\end{array}$ \\
\hline
\end{tabular}

Abbreviation: Aln-allanite; Ap-apatite; Bt-biotite; Ccp-chalcopyrite; Cst-cassiterite; Chl-chlorite; $\mathrm{MgChl}$-Mg-bearing chlorite; Ep_epidote; Ilm-ilmenite; Kfs_-potassic feldspar; Lx-leucoxene; Mag-magnetite; Mnz-monazite; Pl—plagioclase; Py—pyrite; Rt—rutile; Sch—scheelite; Ser—sericite; Ti-Mag-Ti-bearing magnetite; Ttn-titanite; Qz-quartz; Wol—wolframite; Xtm-xenotime; Zrn—zircon; Mol—molybdenite. 


\section{Appendix C}

Table A3. SHRIMP data for zircons from porphyritic monzogranites from the Karkonosze Pluton and its eastern metamorphic cover.

\begin{tabular}{|c|c|c|c|c|c|c|c|c|c|c|c|c|c|c|c|c|c|c|c|c|c|c|c|c|c|}
\hline \multirow{2}{*}{$\begin{array}{l}\text { Grain. } \\
\text { Spot }\end{array}$} & \multirow{2}{*}{$\begin{array}{l}\mathrm{Pb}^{*} \\
(\mathrm{ppm})\end{array}$} & \multirow{2}{*}{$\underset{(\mathrm{ppm})}{\mathrm{U}}$} & \multirow{2}{*}{$\begin{array}{l}\text { Th } \\
\text { (ppm) }\end{array}$} & \multirow{2}{*}{$\mathrm{Th} / \mathrm{U}$} & \multirow{2}{*}{$\begin{array}{l}{ }^{204} \mathrm{~Pb} / \\
{ }^{206} \mathrm{~Pb}\end{array}$} & \multirow{2}{*}{ $\pm 1 \sigma$} & \multirow{2}{*}{$\mathrm{f} 206 \%$} & \multirow{2}{*}{$\begin{array}{c}{ }^{208} \mathrm{~Pb}^{*} / \\
{ }^{206} \mathrm{~Pb}\end{array}$} & \multirow{2}{*}{ $\pm 1 \sigma$} & \multirow{2}{*}{${ }^{208} \mathrm{~Pb}$ */ } & \multirow{2}{*}{ $\pm 1 \sigma$} & \multirow{2}{*}{$\begin{array}{c}{ }^{206} \mathrm{~Pb} \text { */ } \\
{ }^{238} \mathrm{U}\end{array}$} & \multirow{2}{*}{ $\pm 1 \sigma$} & \multirow{2}{*}{$\begin{array}{c}{ }^{207} \mathrm{~Pb} \text { */ } \\
{ }^{235} \mathrm{U}\end{array}$} & \multirow{2}{*}{ $\pm 1 \sigma$} & \multirow{2}{*}{$\begin{array}{l}{ }^{207} \mathrm{~Pb} * / \\
{ }^{206} \mathrm{~Pb}^{*}\end{array}$} & \multirow{2}{*}{ $\pm 1 \sigma$} & \multicolumn{8}{|c|}{ Date (Ma) } \\
\hline & & & & & & & & & & & & & & & & & & 208/232 & $\pm 1 \sigma$ & $206 / 238$ & $\pm 1 \sigma$ & $207 / 235$ & $\pm 1 \sigma$ & Preferred $^{\wedge}$ & $\pm 1 \sigma$ \\
\hline \multicolumn{26}{|c|}{ M12/porphyritic monzogranite } \\
\hline 1.1 & 90 & 1890 & 450 & 0.24 & $2.60 \times 10^{-7}$ & $4.20 \times 10^{-7}$ & 0.00 & 0.0752 & 0.0009 & 0.0155 & 0.0002 & 0.0494 & 0.0003 & 0.361 & 0.004 & 0.0530 & 0.0005 & 310.5 & 4.0 & 310.5 & 1.6 & 312.6 & 3.2 & 310.4 & 1.7 \\
\hline 2.1 & 69 & 1600 & 530 & 0.33 & $2.33 \times 10^{-3}$ & $1.29 \times 10^{-4}$ & 4.27 & 0.0811 & 0.0054 & 0.0108 & 0.0007 & 0.0439 & 0.0003 & 0.324 & 0.015 & 0.0535 & 0.0025 & 218 & 14 & 276.9 & 1.7 & 285 & 12 & 276.6 & 1.6 \\
\hline 3.1 & 98 & 2100 & 400 & 0.19 & $1.89 \times 10^{-5}$ & $7.46 \times 10^{-6}$ & 0.04 & 0.0567 & 0.0008 & 0.0146 & 0.0002 & 0.0493 & 0.0003 & 0.358 & 0.004 & 0.0526 & 0.0004 & 293.0 & 4.7 & 310.2 & 1.9 & 310.5 & 2.9 & 310.2 & 1.9 \\
\hline 4.1 & 71 & 1410 & 750 & 0.54 & $9.33 \times 10^{-5}$ & $2.48 \times 10^{-5}$ & 0.17 & 0.1571 & 0.0018 & 0.0142 & 0.0002 & 0.0485 & 0.0004 & 0.339 & 0.006 & 0.0508 & 0.0007 & 285.0 & 4.3 & 305.1 & 2.5 & 296.7 & 4.3 & 305.7 & 2.5 \\
\hline 5.1 & 121 & 2500 & 670 & 0.27 & $5.52 \times 10^{-5}$ & $2.14 \times 10^{-5}$ & 0.10 & 0.0801 & 0.0011 & 0.0147 & 0.0002 & 0.0490 & 0.0002 & 0.358 & 0.004 & 0.0530 & 0.0005 & 295.7 & 4.4 & 308.1 & 1.3 & 310.5 & 3.1 & 308.0 & 1.3 \\
\hline 6.1 & 51 & 1080 & 310 & 0.28 & $5.07 \times 10^{-5}$ & $1.85 \times 10^{-5}$ & 0.09 & 0.0835 & 0.0013 & 0.0141 & 0.0003 & 0.0481 & 0.0003 & 0.335 & 0.005 & 0.0505 & 0.0006 & 283.9 & 5.1 & 302.8 & 2.0 & 293.3 & 3.5 & 303.5 & 2.1 \\
\hline 7.1 & 86 & 1800 & 480 & 0.27 & $8.91 \times 10^{-6}$ & $7.02 \times 10^{-6}$ & 0.02 & 0.0741 & 0.0009 & 0.0138 & 0.0002 & 0.0493 & 0.0002 & 0.356 & 0.003 & 0.0524 & 0.0004 & 276.6 & 3.8 & 310.4 & 1.3 & 309.5 & 2.5 & 310.5 & 1.3 \\
\hline 8.1 & 63 & 1340 & 290 & 0.22 & $1.83 \times 10^{-5}$ & $1.55 \times 10^{-5}$ & 0.03 & 0.0678 & 0.0018 & 0.0151 & 0.0004 & 0.0488 & 0.0002 & 0.353 & 0.004 & 0.0525 & 0.0005 & 302.4 & 8.2 & 307.2 & 1.3 & 306.9 & 2.9 & 307.2 & 1.3 \\
\hline 9.1 & 99 & 2100 & 530 & 0.25 & $2.00 \times 10^{-5}$ & $2.00 \times 10^{-5}$ & 0.04 & 0.0766 & 0.0011 & 0.0149 & 0.0002 & 0.0490 & 0.0002 & 0.355 & 0.004 & 0.0525 & 0.0005 & 298.1 & 4.5 & 308.3 & 1.5 & 308.4 & 3.1 & 308.3 & 1.5 \\
\hline 10.1 & 75 & 1570 & 460 & 0.29 & $4.01 \times 10^{-5}$ & $1.76 \times 10^{-5}$ & 0.07 & 0.0884 & 0.0016 & 0.0148 & 0.0003 & 0.0488 & 0.0003 & 0.353 & 0.006 & 0.0524 & 0.0008 & 297.6 & 5.6 & 307.4 & 1.8 & 307.0 & 4.4 & 307.5 & 1.9 \\
\hline 11.1 & 79 & 1630 & 530 & 0.33 & $2.00 \times 10^{-5}$ & $2.00 \times 10^{-5}$ & 0.04 & 0.0983 & 0.0017 & 0.0148 & 0.0003 & 0.0492 & 0.0002 & 0.351 & 0.004 & 0.0517 & 0.0005 & 297.1 & 5.4 & 309.6 & 1.4 & 305.3 & 3.0 & 309.9 & 1.4 \\
\hline 12.1 & 54 & 1120 & 380 & 0.34 & $5.95 \times 10^{-5}$ & $1.87 \times 10^{-5}$ & 0.11 & 0.1090 & 0.0023 & 0.0154 & 0.0003 & 0.0481 & 0.0003 & 0.357 & 0.005 & 0.0538 & 0.0007 & 309.7 & 6.7 & 302.5 & 2.0 & 309.7 & 4.0 & 302.1 & 2.0 \\
\hline 13.1 & 58 & 1250 & 220 & 0.17 & $5.82 \times 10^{-5}$ & $1.86 \times 10^{-5}$ & 0.11 & 0.0524 & 0.0011 & 0.0145 & 0.0003 & 0.0484 & 0.0003 & 0.350 & 0.005 & 0.0525 & 0.0007 & 291.0 & 6.4 & 304.7 & 1.6 & 304.9 & 4.0 & 304.7 & 1.6 \\
\hline & t/porph & itic m & nzograni & & & & & & & & & & & & & & & & & & & & & & \\
\hline 1.1 & 12 & 220 & 138 & 0.62 & $1.05 \times 10^{-4}$ & $8.79 \times 10^{-5}$ & 0.19 & 0.1843 & 0.0057 & 0.0154 & 0.0005 & 0.0515 & 0.0006 & 0.366 & 0.015 & 0.0515 & 0.0019 & 310 & 10 & 323.7 & 3.9 & 316 & 11 & 324.1 & 3.9 \\
\hline 2.1 & 42 & 850 & 270 & 0.32 & $1.56 \times 10^{-5}$ & $2.46 \times 10^{-5}$ & 0.03 & 0.0977 & 0.0025 & 0.0156 & 0.0004 & 0.0504 & 0.0004 & 0.355 & 0.006 & 0.0511 & 0.0007 & 312.4 & 8.5 & 316.7 & 2.4 & 308.2 & 4.5 & 317.3 & 2.4 \\
\hline 3.1 & 47 & 830 & 760 & 0.92 & $1.93 \times 10^{-5}$ & $1.19 \times 10^{-5}$ & 0.04 & 0.2755 & 0.0028 & 0.0150 & 0.0002 & 0.0500 & 0.0005 & 0.360 & 0.007 & 0.0522 & 0.0007 & 301.6 & 4.6 & 314.4 & 3.1 & 311.9 & 4.9 & 314.6 & 3.1 \\
\hline 4.1 & 31 & 630 & 220 & 0.35 & $1.96 \times 10^{-5}$ & $2.46 \times 10^{-5}$ & 0.04 & 0.1055 & 0.0022 & 0.0152 & 0.0004 & 0.0496 & 0.0007 & 0.361 & 0.012 & 0.0528 & 0.0015 & 303.8 & 7.9 & 311.9 & 4.0 & 312.7 & 8.9 & 311.8 & 4.1 \\
\hline 5.1 & 21 & 450 & 135 & 0.30 & $2.00 \times 10^{-5}$ & $2.00 \times 10^{-5}$ & 0.04 & 0.0948 & 0.0020 & 0.0150 & 0.0003 & 0.0478 & 0.0004 & 0.359 & 0.008 & 0.0545 & 0.0011 & 300.7 & 6.8 & 301.2 & 2.5 & 311.6 & 6.2 & 300.5 & 2.6 \\
\hline 6.1 & 20 & 400 & 170 & 0.42 & $7.22 \times 10^{-5}$ & $3.48 \times 10^{-5}$ & 0.13 & 0.1296 & 0.0029 & 0.0151 & 0.0004 & 0.0493 & 0.0005 & 0.349 & 0.011 & 0.0513 & 0.0015 & 303.6 & 7.4 & 310.2 & 2.8 & 303.7 & 8.3 & 310.7 & 2.8 \\
\hline 7.1 & 16 & 300 & 180 & 0.60 & $2.00 \times 10^{-5}$ & $2.00 \times 10^{-5}$ & 0.04 & 0.1889 & 0.0032 & 0.0156 & 0.0004 & 0.0495 & 0.0006 & 0.367 & 0.009 & 0.0538 & 0.0010 & 313.6 & 7.1 & 311.3 & 3.9 & 317.3 & 6.6 & 310.8 & 4.0 \\
\hline 8.1 & 21 & 430 & 174 & 0.41 & $2.00 \times 10^{-5}$ & $2.00 \times 10^{-5}$ & 0.04 & 0.1275 & 0.0023 & 0.0154 & 0.0003 & 0.0492 & 0.0004 & 0.353 & 0.009 & 0.0520 & 0.0013 & 308.4 & 6.3 & 309.4 & 2.5 & 306.8 & 7.1 & 309.6 & 2.6 \\
\hline 9.1 & 47 & 980 & 300 & 0.30 & $3.19 \times 10^{-5}$ & $2.10 \times 10^{-5}$ & 0.06 & 0.0908 & 0.0023 & 0.0146 & 0.0004 & 0.0484 & 0.0003 & 0.349 & 0.005 & 0.0524 & 0.0006 & 293.5 & 7.7 & 304.5 & 1.6 & 304.3 & 3.6 & 304.6 & 1.6 \\
\hline 10.1 & 37 & 750 & 250 & 0.33 & $2.35 \times 10^{-5}$ & $1.37 \times 10^{-5}$ & 0.04 & 0.1015 & 0.0020 & 0.0154 & 0.0003 & 0.0494 & 0.0004 & 0.350 & 0.007 & 0.0514 & 0.0009 & 308.1 & 6.8 & 310.9 & 2.6 & 304.8 & 5.5 & 311.4 & 2.6 \\
\hline 11.1 & 24 & 500 & 177 & 0.35 & $4.45 \times 10^{-5}$ & $1.84 \times 10^{-5}$ & 0.08 & 0.1088 & 0.0024 & 0.0150 & 0.0004 & 0.0490 & 0.0006 & 0.344 & 0.010 & 0.0509 & 0.0013 & 301.5 & 7.5 & 308.0 & 3.5 & 300.0 & 7.5 & 308.7 & 3.5 \\
\hline 12.1 & 28 & 560 & 210 & 0.38 & $2.00 \times 10^{-5}$ & $2.00 \times 10^{-5}$ & 0.04 & 0.1193 & 0.0041 & 0.0154 & 0.0006 & 0.0492 & 0.0005 & 0.353 & 0.009 & 0.0521 & 0.0011 & 309 & 11 & 309.8 & 3.0 & 307.3 & 6.4 & 310.0 & 3.0 \\
\hline 13.1 & 28 & 570 & 240 & 0.41 & $1.15 \times 10^{-5}$ & $1.33 \times 10^{-5}$ & 0.02 & 0.1304 & 0.0023 & 0.0154 & 0.0003 & 0.0488 & 0.0004 & 0.346 & 0.010 & 0.0515 & 0.0013 & 308.8 & 6.2 & 307.0 & 2.7 & 301.9 & 7.4 & 307.4 & 2.7 \\
\hline 14.1 & 27 & 540 & 178 & 0.33 & $2.00 \times 10^{-5}$ & $2.00 \times 10^{-5}$ & 0.04 & 0.1002 & 0.0019 & 0.0151 & 0.0004 & 0.0494 & 0.0006 & 0.356 & 0.007 & 0.0523 & 0.0008 & 303.2 & 7.0 & 310.9 & 3.4 & 309.2 & 5.4 & 311.0 & 3.4 \\
\hline 15.1 & 49 & 1000 & 380 & 0.38 & $2.00 \times 10^{-5}$ & $2.00 \times 10^{-5}$ & 0.04 & 0.1168 & 0.0019 & 0.0151 & 0.0003 & 0.0493 & 0.0004 & 0.353 & 0.007 & 0.0519 & 0.0008 & 303.6 & 5.6 & 310.3 & 2.6 & 306.6 & 5.1 & 310.6 & 2.7 \\
\hline 16.1 & 38 & 760 & 380 & 0.50 & $8.55 \times 10^{-5}$ & $2.81 \times 10^{-5}$ & 0.16 & 0.1518 & 0.0021 & 0.0147 & 0.0002 & 0.0489 & 0.0003 & 0.338 & 0.008 & 0.0501 & 0.0011 & 295.3 & 4.5 & 307.8 & 1.6 & 295.4 & 6.2 & 308.8 & 1.7 \\
\hline
\end{tabular}


Table A3. Cont.

\begin{tabular}{|c|c|c|c|c|c|c|c|c|c|c|c|c|c|c|c|c|c|c|c|c|c|c|c|c|c|}
\hline \multirow{2}{*}{$\begin{array}{l}\text { Grain. } \\
\text { Spot }\end{array}$} & \multirow{2}{*}{$\begin{array}{l}\mathrm{Pb}^{*} \\
(\mathrm{ppm})\end{array}$} & \multirow{2}{*}{$\underset{(\mathrm{ppm})}{\mathrm{U}}$} & \multirow{2}{*}{$\begin{array}{c}\text { Th } \\
\text { (ppm) }\end{array}$} & \multirow{2}{*}{$\mathrm{Th} / \mathrm{U}$} & \multirow{2}{*}{$\begin{array}{l}{ }^{204} \mathrm{~Pb} / \\
{ }^{206} \mathrm{~Pb}\end{array}$} & \multirow{2}{*}{ $\pm 1 \sigma$} & \multirow{2}{*}{$\mathrm{f} 206 \%$} & \multirow{2}{*}{$\begin{array}{c}{ }^{208} \mathrm{~Pb} * / \\
{ }^{206} \mathrm{~Pb}\end{array}$} & \multirow{2}{*}{ $\pm 1 \sigma$} & \multirow{2}{*}{$\begin{array}{l}{ }^{208} \mathrm{~Pb} * / \\
{ }^{232} \mathrm{Th}\end{array}$} & \multirow{2}{*}{ $\pm 1 \sigma$} & \multirow{2}{*}{$\begin{array}{c}{ }^{206} \mathrm{~Pb} * / \\
{ }^{238} \mathrm{U}\end{array}$} & \multirow{2}{*}{ $\pm 1 \sigma$} & \multirow{2}{*}{$\begin{array}{c}{ }^{207} \mathrm{~Pb} * / \\
{ }^{235} \mathrm{U}\end{array}$} & \multirow{2}{*}{ $\pm 1 \sigma$} & \multirow{2}{*}{$\begin{array}{l}{ }^{207} \mathrm{~Pb} \text { */ } \\
{ }^{206} \mathrm{~Pb}^{*}\end{array}$} & \multirow{2}{*}{ $\pm 1 \sigma$} & \multicolumn{8}{|c|}{ Date (Ma) } \\
\hline & & & & & & & & & & & & & & & & & & $208 / 232$ & $\pm 1 \sigma$ & $206 / 238$ & $\pm 1 \sigma$ & $207 / 235$ & $\pm 1 \sigma$ & Preferred^ & \pm 10 \\
\hline \multicolumn{26}{|c|}{ C13/porphyritic monzogranite } \\
\hline 1.1 & 11 & 200 & 105 & 0.51 & $2.00 \times 10^{-5}$ & $2.00 \times 10^{-5}$ & 0.04 & 0.1672 & 0.0047 & 0.0165 & 0.0005 & 0.0507 & 0.0007 & 0.369 & 0.011 & 0.0528 & 0.0012 & 2331 & 10 & 318.9 & 4.1 & 319.1 & 7.8 & 318.8 & 4.2 \\
\hline 2.1 & 11 & 220 & 86 & 0.39 & $2.93 \times 10^{-5}$ & $4.10 \times 10^{-5}$ & 0.01 & 0.1163 & 0.0043 & 0.0153 & 0.0006 & 0.0506 & 0.0008 & 0.356 & 0.016 & 0.0510 & 0.0021 & 1306 & 13 & 317.9 & 5.2 & 309 & 12 & 318.5 & 5.2 \\
\hline 3.1 & 27 & 550 & 154 & 0.28 & $3.90 \times 10^{-5}$ & $2.93 \times 10^{-5}$ & 0.07 & 0.0846 & 0.0020 & 0.0151 & 0.0004 & 0.0496 & 0.0004 & 0.359 & 0.010 & 0.0526 & 0.0013 & 3301.9 & 7.7 & 312.1 & 2.4 & 311.8 & 7.2 & 312.1 & 2.4 \\
\hline 3.2 & 26 & 540 & 153 & 0.29 & $2.00 \times 10^{-5}$ & $2.00 \times 10^{-5}$ & 0.04 & 0.0886 & 0.0021 & 0.0153 & 0.0004 & 0.0492 & 0.0004 & 0.356 & 0.007 & 0.0525 & 0.0009 & 9305.8 & 7.7 & 309.6 & 2.3 & 309.5 & 5.3 & 309.6 & 2.3 \\
\hline 4.1 & 10 & 196 & 84 & 0.43 & $4.40 \times 10^{-6}$ & $6.80 \times 10^{-6}$ & 0.01 & 0.1365 & 0.0038 & 0.0159 & 0.0005 & 0.0494 & 0.0006 & 0.360 & 0.012 & 0.0529 & 0.0015 & 5317.8 & 9.8 & 310.6 & 3.5 & 312.5 & 8.8 & 310.5 & 3.6 \\
\hline 5.1 & 30 & 560 & 400 & 0.72 & $1.85 \times 10^{-3}$ & $2.78 \times 10^{-4}$ & 3.38 & 0.2168 & 0.0114 & 0.0149 & 0.0008 & 0.0498 & 0.0006 & 0.341 & 0.033 & 0.0497 & 0.0046 & $6 \quad 300$ & 16 & 313.3 & 3.6 & 298 & 25 & 314.4 & 3.3 \\
\hline 6.1 & 13 & 250 & 110 & 0.44 & $2.00 \times 10^{-5}$ & $2.00 \times 10^{-5}$ & 0.04 & 0.1331 & 0.0035 & 0.0149 & 0.0005 & 0.0496 & 0.0007 & 0.351 & 0.012 & 0.0514 & 0.0016 & 6298.3 & 9.2 & 311.8 & 4.4 & 305.4 & 9.3 & 312.2 & 4.5 \\
\hline 7.1 & 24 & 460 & 320 & 0.69 & $9.45 \times 10^{-5}$ & $8.16 \times 10^{-5}$ & 0.17 & 0.2055 & 0.0045 & 0.0144 & 0.0004 & 0.0485 & 0.0006 & 0.343 & 0.012 & 0.0513 & 0.0016 & 6288.6 & 7.4 & 305.1 & 3.4 & 299.5 & 8.9 & 305.6 & 3.4 \\
\hline 8.1 & 26 & 510 & 200 & 0.39 & $2.00 \times 10^{-5}$ & $2.00 \times 10^{-5}$ & 0.04 & 0.1208 & 0.0029 & 0.0152 & 0.0004 & 0.0496 & 0.0007 & 0.355 & 0.013 & 0.0520 & 0.0016 & $6 \quad 305.7$ & 8.8 & 311.9 & 4.3 & 309 & 10 & 312.1 & 4.4 \\
\hline 9.1 & 18 & 370 & 130 & 0.35 & $1.95 \times 10^{-4}$ & $1.28 \times 10^{-4}$ & 0.36 & 0.1044 & 0.0063 & 0.0146 & 0.0009 & 0.0493 & 0.0007 & 0.334 & 0.017 & 0.0492 & 0.0023 & $3 \quad 293$ & 18 & 310.4 & 4.6 & 293 & 13 & 311.7 & 4.5 \\
\hline 10.1 & 6 & 120 & 64 & 0.54 & $2.00 \times 10^{-5}$ & $2.00 \times 10^{-5}$ & 0.04 & 0.1732 & 0.0076 & 0.0158 & 0.0008 & 0.0490 & 0.0010 & 0.356 & 0.016 & 0.0528 & 0.0020 & $0 \quad 316$ & 15 & 308.1 & 5.9 & 309 & 12 & 308.0 & 5.9 \\
\hline 11.1 & 12 & 230 & 133 & 0.59 & $1.17 \times 10^{-4}$ & $1.10 \times 10^{-4}$ & 0.21 & 0.1755 & 0.0062 & 0.0149 & 0.0006 & 0.0499 & 0.0011 & 0.353 & 0.018 & 0.0512 & 0.0022 & $2 \quad 298$ & 13 & 314.1 & 6.6 & 307 & 14 & 314.6 & 6.6 \\
\hline 12.1 & 17 & 340 & 142 & 0.42 & $4.91 \times 10^{-6}$ & $1.08 \times 10^{-5}$ & 0.01 & 0.1358 & 0.0031 & 0.0161 & 0.0004 & 0.0498 & 0.0005 & 0.372 & 0.012 & 0.0542 & 0.0015 & 5321.9 & 8.4 & 313.1 & 3.3 & 321.2 & 8.8 & 312.5 & 3.4 \\
\hline 13.1 & 15 & 280 & 172 & 0.60 & $6.93 \times 10^{-5}$ & $4.14 \times 10^{-5}$ & 0.13 & 0.1868 & 0.0043 & 0.0155 & 0.0004 & 0.0500 & 0.0007 & 0.338 & 0.011 & 0.0489 & 0.0014 & 4310.5 & 8.5 & 314.7 & 4.2 & 295.3 & 8.7 & 316.1 & 4.2 \\
\hline
\end{tabular}

Table A4. cont. SHRIMP data of zircons from equigranular monzogranites and rhyolite porphyry from the Karkonosze Pluton and its eastern metamorphic cover.

\begin{tabular}{|c|c|c|c|c|c|c|c|c|c|c|c|c|c|c|c|c|c|c|c|c|c|c|c|c|c|}
\hline \multirow{2}{*}{$\begin{array}{l}\text { Grain. } \\
\text { Spot }\end{array}$} & \multirow{2}{*}{$\begin{array}{l}\mathrm{Pb}^{*} \\
(\mathrm{ppm})\end{array}$} & \multirow{2}{*}{$\underset{(\mathrm{ppm})}{\mathrm{U}}$} & \multirow{2}{*}{$\begin{array}{c}\text { Th } \\
\text { (ppm) }\end{array}$} & \multirow{2}{*}{$\mathrm{Th} / \mathrm{U}$} & \multirow{2}{*}{${ }^{204} \mathrm{~Pb} /$} & \multirow{2}{*}{ $\pm 1 \sigma$} & \multirow{2}{*}{$\mathrm{f} 206 \%$} & \multirow{2}{*}{$\begin{array}{c}{ }^{208} \mathrm{~Pb} * / \\
{ }^{206} \mathrm{~Pb}\end{array}$} & \multirow{2}{*}{ $\pm 1 \sigma$} & \multirow{2}{*}{$\begin{array}{c}{ }^{208} \mathrm{~Pb} * / \\
{ }^{232} \mathrm{Th}\end{array}$} & \multirow{2}{*}{ $\pm 1 \sigma$} & \multirow{2}{*}{$\begin{array}{c}{ }^{206} \mathrm{~Pb}^{*} / \\
{ }^{238} \mathrm{U}\end{array}$} & \multirow{2}{*}{ $\pm 1 \sigma$} & \multirow{2}{*}{$\begin{array}{c}{ }^{207} \mathrm{~Pb}^{*} \\
{ }^{235} \mathrm{U}\end{array}$} & \multirow{2}{*}{ $\pm 1 \sigma$} & \multirow{2}{*}{$\begin{array}{l}{ }^{207} \mathrm{~Pb}^{*} / \\
{ }^{206} \mathrm{~Pb}\end{array}$} & \multirow{2}{*}{ $\pm 1 \sigma$} & \multicolumn{8}{|c|}{ Date (Ma) } \\
\hline & & & & & & & & & & & & & & & & & & $208 / 232$ & $\pm 1 \sigma$ & $206 / 238$ & $\pm 1 \sigma$ & $207 / 235$ & $\pm 1 \sigma$ & Preferred ${ }^{\wedge}$ & $\pm 1 \sigma$ \\
\hline \multicolumn{26}{|c|}{ S1/equigranular monzogranite } \\
\hline 1.1 & 82 & 1760 & 510 & 0.29 & $7.93 \times 10^{-4}$ & $9.50 \times 10^{-5}$ & 1.45 & 0.0870 & 0.0038 & 0.0142 & 0.0006 & 0.0477 & 0.0003 & 0.337 & 0.012 & 0.0511 & 0.0017 & $7 \quad 284$ & 13 & 300.7 & 2.1 & 294.5 & 9.1 & 301.1 & 2.0 \\
\hline 2.1 & 80 & 1730 & 440 & 0.26 & $5 \times 10^{-4}$ & $63 \times 10^{-5}$ & 0.56 & & 0.0020 & & 0.0004 & 0.0478 & 0.0006 & & 0.009 & & 0.0012 & 269.3 & 8.5 & & 3.8 & 296.4 & 7.0 & 301.0 & 3.8 \\
\hline 3.1 & 69 & 1590 & 460 & 0.29 & $6.20 \times 10^{-3}$ & $2.27 \times 10^{-4}$ & 11.35 & 0.0607 & 0.0097 & 0.0 & 0.0015 & 0.0458 & 0.0003 & & 0.027 & 0.0452 & 0.0043 & 3191 & 30 & 38.5 & 1.8 & 255 & 22 & 291.0 & 1.4 \\
\hline 4.1 & 83 & 1810 & 380 & 0.21 & $6.48 \times 10^{-5}$ & $2.19 \times 10^{-5}$ & 0.12 & 0.0634 & 0.0012 & 0.0144 & 0.0003 & 0.0478 & 0.0003 & 0.351 & 0.005 & 0.0533 & 0.0006 & 6288.8 & 5.9 & 301.0 & 1.9 & 305.6 & 3.7 & 300.7 & 1.9 \\
\hline 5.1 & 61 & 1360 & 600 & 0.44 & $2.19 \times 10^{-4}$ & $7.69 \times 10^{-5}$ & 0.40 & 0.0819 & 0.0034 & 0.0085 & 0.0004 & 0.0463 & 0.0004 & 0.332 & 0.009 & 0.0520 & 0.0013 & $\begin{array}{ll}3 & 171.6\end{array}$ & 7.3 & 291.6 & 2.4 & 291.0 & 7.1 & 291.7 & 2.4 \\
\hline 6.1 & 108 & 2200 & 650 & 0.29 & $0^{-5}$ & $1.23 \times 10^{-5}$ & 0.03 & 0.0901 & 0.0010 & 0.0153 & 0.0002 & 0.0491 & 0.0002 & 0.356 & 0.005 & 0.0526 & 0.0006 & 6306.1 & 3.7 & 308.7 & 1.2 & 308.9 & 3.5 & 308.6 & 1.3 \\
\hline 7.1 & 50 & 1070 & 510 & 0.48 & $6.52 \times 10^{-4}$ & $7.16 \times 10^{-5}$ & 1.19 & 0.1031 & 0.0037 & 0.0103 & 0.0004 & 0.0473 & 0.0010 & 0.353 & 0.013 & 0.0540 & 0.0015 & 5206.1 & 8.8 & 298.1 & 5.9 & 307 & 10 & 297.5 & 5.9 \\
\hline 8.1 & 63 & 1340 & 310 & 0.23 & $5.55 \times 10^{-5}$ & $2.98 \times 10^{-5}$ & 0.10 & 0.0700 & 0.0015 & 0.0149 & 0.0003 & 0.0489 & 0.0002 & 0.354 & 0.006 & 0.0526 & 0.0008 & $\begin{array}{ll}8299.7 \\
\end{array}$ & 6.6 & 307.9 & 1.4 & 308.0 & 4.1 & 307.8 & 1.4 \\
\hline 9.1 & 92 & 1960 & & & $7.86 \times 10^{-6}$ & $4.85 \times 10^{-6}$ & 0.01 & & & & & & & & & & & 4297.6 & 4.3 & & 0.9 & & 2.5 & & 0.9 \\
\hline 10.1 & 47 & 1070 & 330 & 0.30 & $1.57 \times 10^{-4}$ & $3.24 \times 10^{-5}$ & 0.29 & 0.0822 & 0.0017 & 0.0121 & 0.0003 & 0.0445 & 0.0003 & 0.330 & 0.008 & 0.0538 & 0.0011 & 242.3 & 5.3 & 280.5 & 1.8 & 289.4 & 5.8 & 280.0 & 1.8 \\
\hline 11.1 & 80 & 1720 & 320 & 0.19 & $4.48 \times 10^{-6}$ & $4.22 \times 10^{-6}$ & 0.01 & 0.0579 & 0.0014 & 0.0150 & 0.0008 & 0.0485 & 0.0019 & 0.349 & 0.019 & 0.0521 & 0.0017 & $7 \quad 300$ & 15 & 305 & 12 & 304 & 14 & 305 & 12 \\
\hline 12.1 & 84 & 1870 & 430 & 0.23 & $2.79 \times 1$ & $3.25 \times 10^{-5}$ & 0.51 & 0.0678 & 0.0017 & 0.0136 & 0.0004 & 0.0466 & 0.0003 & 0.340 & 0.006 & 0.0530 & 0.0008 & 8272.9 & 6.9 & 293.7 & 1.6 & 297.5 & 4.3 & 293.4 & 1.6 \\
\hline 13.1 & 78 & 1700 & 420 & 0.25 & $3.05 \times 10^{-5}$ & $1.15 \times 10^{-5}$ & 0.06 & 0.0762 & 0.0010 & 0.0146 & 0.0002 & 0.0475 & 0.0003 & 0.336 & 0.004 & 0.0513 & 0.0005 & 5292.9 & 4.5 & 298.9 & 1.8 & 293.8 & 2.9 & 299.3 & 1.8 \\
\hline 14.1 & 91 & 1890 & 630 & 0.33 & $1.43 \times 10^{-5}$ & $7.96 \times 10^{-6}$ & 0.03 & & 0.0016 & & & & & & & & 0.0005 & 5300.0 & 4.9 & 305.9 & 1.6 & 304.4 & 3.0 & 306.0 & 1.6 \\
\hline 15.1 & 80 & 1690 & 510 & 0.30 & $1.69 \times 10^{-4}$ & $3.59 \times 10^{-5}$ & 0.31 & 0.0925 & 0.0021 & 0.0147 & 0.0003 & 0.0480 & 0.0003 & 0.345 & 0.005 & 0.0521 & 0.0007 & $7 \quad 295.2$ & 6.8 & 302.4 & 1.5 & 301.1 & 4.0 & 302.5 & 1.5 \\
\hline 16.1 & 153 & 3300 & 750 & 0.23 & $3.53 \times 10^{-5}$ & $1.12 \times 10^{-5}$ & 0.07 & 0.0650 & 0.0007 & 0.0138 & 0.0002 & 0.0478 & 0.0002 & 0.346 & 0.003 & 0.0524 & 0.0004 & $\begin{array}{l}4276.0 \\
4\end{array}$ & 3.4 & 301.0 & 1.3 & 301.3 & 2.5 & 300.9 & 1.3 \\
\hline
\end{tabular}


Table A4. Cont.

\begin{tabular}{|c|c|c|c|c|c|c|c|c|c|c|c|c|c|c|c|c|c|c|c|c|c|c|c|c|c|}
\hline \multirow{2}{*}{$\begin{array}{l}\text { Grain. } \\
\text { Spot }\end{array}$} & \multirow{2}{*}{$\begin{array}{l}\mathrm{Pb}^{*} \\
(\mathrm{ppm})\end{array}$} & \multirow{2}{*}{$\underset{(\mathrm{ppm})}{\mathrm{U}}$} & \multirow{2}{*}{$\begin{array}{l}\text { Th } \\
(\mathrm{ppm})\end{array}$} & \multirow{2}{*}{$\mathrm{Th} / \mathrm{U}$} & \multirow{2}{*}{$\begin{array}{l}{ }^{204} \mathrm{~Pb} / \\
{ }^{206} \mathrm{~Pb}\end{array}$} & \multirow{2}{*}{ $\pm 1 \sigma$} & \multirow{2}{*}{ f206\% } & \multirow{2}{*}{$\begin{array}{c}{ }^{208} \mathrm{~Pb} * / \\
{ }^{206} \mathrm{~Pb}\end{array}$} & \multirow{2}{*}{ $\pm 1 \sigma$} & \multirow{2}{*}{$\begin{array}{c}{ }^{208} \mathrm{~Pb} * / \\
{ }^{232} \mathrm{Th}\end{array}$} & \multirow{2}{*}{ $\pm 1 \sigma$} & \multirow{2}{*}{$\begin{array}{c}{ }^{206} \mathrm{~Pb} * / \\
{ }^{238} \mathrm{U}\end{array}$} & \multirow{2}{*}{ $\pm 1 \sigma$} & \multirow{2}{*}{${ }^{207} \mathrm{~Pb} * /$} & \multirow{2}{*}{ $\pm 1 \sigma$} & \multirow{2}{*}{$\begin{array}{l}{ }^{207} \mathrm{~Pb} * \\
{ }^{206} \mathrm{~Pb} \text { * }\end{array}$} & \multirow{2}{*}{ $\pm 1 \sigma$} & \multicolumn{8}{|c|}{ Date (Ma) } \\
\hline & & & & & & & & & & & & & & & & & & $208 / 232$ & $\pm 1 \sigma$ & $206 / 238$ & $\pm 1 \sigma$ & $207 / 235$ & $\pm 1 \sigma$ & Preferred $^{\wedge}$ & $\pm 1 \sigma$ \\
\hline \multicolumn{26}{|c|}{ J15/equigranular monzogranite } \\
\hline 1.1 & 20 & 400 & 156 & 0.39 & $7.38 \times 10^{-6}$ & $6.95 \times 10^{-6}$ & 0.01 & 0.1193 & 0.0025 & 0.0153 & 0.0004 & 0.0501 & 0.0005 & 0.374 & 0.009 & 0.0542 & 0.0012 & 2307.7 & 7.4 & 314.8 & 3.2 & 322.5 & 6.9 & 314.1 & 3.2 \\
\hline 2.1 & 42 & 870 & 280 & 0.32 & $2.00 \times 10^{-5}$ & $2.00 \times 10^{-5}$ & 0.04 & 0.0972 & 0.0033 & 0.0148 & 0.0005 & 0.0485 & 0.0004 & 0.356 & 0.007 & 0.0532 & 0.0009 & 9297 & 11 & 305.2 & 2.6 & 308.9 & 5.2 & 304.9 & 2.6 \\
\hline 3.1 & 22 & 450 & 171 & 0.38 & $8.90 \times 10^{-5}$ & $8.13 \times 10^{-5}$ & 0.16 & 0.1195 & 0.0043 & 0.0154 & 0.0006 & 0.0491 & 0.0004 & 0.353 & 0.015 & 0.0522 & 0.0021 & 1308 & 11 & 308.8 & 2.4 & 307 & 11 & 308.9 & 2.4 \\
\hline 4.1 & 27 & 570 & 210 & 0.37 & $6.87 \times 10^{-5}$ & $4.39 \times 10^{-5}$ & 0.13 & 0.1166 & 0.0032 & 0.0148 & 0.0004 & 0.0476 & 0.0005 & 0.351 & 0.012 & 0.0535 & 0.0017 & 7297.2 & 8.7 & 300.0 & 2.8 & 305.5 & 8.9 & 299.6 & 2.9 \\
\hline 5.1 & 194 & 5000 & 1540 & 0.31 & $3.96 \times 10^{-4}$ & $3.55 \times 10^{-5}$ & 0.73 & 0.0846 & 0.0015 & 0.0109 & 0.0002 & 0.0402 & 0.0002 & 0.284 & 0.005 & 0.0513 & 0.0008 & 8219.2 & 4.1 & 253.9 & 1.0 & 254.0 & 3.8 & 254.3 & 1.0 \\
\hline 6.1 & 16 & 320 & 220 & 0.69 & $4.01 \times 10^{-4}$ & $9.59 \times 10^{-5}$ & 0.73 & 0.2013 & 0.0075 & 0.0131 & 0.0008 & 0.0450 & 0.0017 & 0.313 & 0.018 & 0.0505 & 0.0018 & $8 \quad 264$ & 16 & 284 & 11 & 277 & 14 & 284 & 11 \\
\hline 7.1 & 24 & 510 & 220 & 0.43 & $1.26 \times 10^{-4}$ & $8.11 \times 10^{-5}$ & 0.23 & 0.1143 & 0.0040 & 0.0123 & 0.0005 & 0.0456 & 0.0004 & 0.338 & 0.013 & 0.0537 & 0.0020 & 246.3 & 8.9 & 287.7 & 2.2 & 295 & 10 & 287.3 & 2.3 \\
\hline 8.1 & 21 & 430 & 177 & 0.42 & $3.54 \times 10^{-5}$ & $2.77 \times 10^{-5}$ & 0.07 & 0.1241 & 0.0031 & 0.0146 & 0.0004 & 0.0490 & 0.0005 & 0.352 & 0.011 & & 0.0014 & $\begin{array}{l}4293.2 \\
\end{array}$ & 7.9 & 308.2 & 3.2 & 306.3 & 8.0 & 308.4 & 3.2 \\
\hline 9.1 & 12 & 250 & 69 & 0.28 & $2.00 \times 10^{-5}$ & $2.00 \times 10^{-5}$ & 0.04 & 0.0874 & 0.0023 & 0.0158 & 0.0005 & 0.0508 & 0.0007 & 0.367 & 0.016 & 0.0525 & 0.0021 & 1317.2 & 9.7 & 319.2 & 4.1 & 318 & 12 & 319.2 & 4.2 \\
\hline 10.1 & 57 & 1160 & 410 & 0.35 & $2.00 \times 10^{-5}$ & $2.00 \times 10^{-5}$ & 0.04 & 0.1063 & 0.0015 & 0.0149 & 0.0002 & 0.0488 & 0.0003 & 0.351 & 0.005 & 0.0521 & 0.0007 & 7298.1 & 4.8 & 307.2 & 1.7 & 305.4 & 3.9 & 296.8 & 2.8 \\
\hline 11.1 & 25 & 520 & 220 & 0.42 & $4.21 \times 10^{-4}$ & $1.84 \times 10^{-4}$ & 0.77 & 0.1169 & 0.0076 & 0.0129 & 0.0009 & 0.0470 & 0.0005 & 0.328 & 0.021 & 0.0506 & 0.0031 & 1260 & 17 & 296.2 & 3.0 & 288 & 16 & 307.3 & 1.7 \\
\hline 12.1 & 25 & 500 & 176 & 0.35 & $8.34 \times 10^{-6}$ & $8.85 \times 10^{-6}$ & 0.02 & 0.1099 & 0.0024 & 0.0154 & 0.0004 & 0.0497 & 0.0004 & 0.358 & 0.006 & 0.0523 & 0.0008 & 8309.7 & 7.3 & 312.8 & 2.2 & 311.0 & 4.6 & 312.9 & 2.3 \\
\hline \multicolumn{26}{|c|}{ M2/rhyolite } \\
\hline 1.1 & 97 & 1970 & 1170 & 0.60 & $4.83 \times 10^{-6}$ & $3.80 \times 10^{-6}$ & 0.01 & 0.1864 & 0.0017 & 0.0145 & 0.0002 & 0.0462 & 0.0003 & 0.334 & 0.005 & 0.0525 & 0.0006 & $\begin{array}{ll}6 & 290.3\end{array}$ & 3.5 & 291.2 & 1.9 & 292.8 & 3.5 & 291.2 & 1.9 \\
\hline 2.1 & 105 & 2100 & 1180 & 0.56 & $1.99 \times 10^{-5}$ & $9.25 \times 10^{-6}$ & 0.04 & 0.1703 & 0.0011 & 0.0144 & 0.0001 & 0.0472 & 0.0002 & 0.345 & 0.004 & 0.0531 & 0.0006 & $6 \quad 288.2$ & 2.2 & 297.2 & 1.0 & 301.2 & 3.2 & 296.9 & 1.1 \\
\hline 3.1 & 87 & 1750 & 710 & 0.40 & $4.29 \times 10^{-5}$ & $1.36 \times 10^{-5}$ & 0.08 & 0.1244 & 0.0024 & 0.0151 & 0.0003 & 0.0493 & 0.0004 & 0.355 & 0.005 & 0.0523 & 0.0005 & 5303.8 & 6.6 & 309.9 & 2.6 & 308.5 & 3.5 & 309.9 & 2.6 \\
\hline 4.1 & 99 & 1970 & 1080 & 0.55 & $3.03 \times 10^{-5}$ & $9.06 \times 10^{-6}$ & 0.06 & 0.1702 & 0.0012 & 0.0149 & 0.0001 & 0.0481 & 0.0002 & 0.341 & 0.004 & 0.0514 & 0.0005 & $5 \quad 298.4$ & 2.7 & 303.0 & 1.5 & 298.2 & 2.9 & 303.3 & 1.5 \\
\hline 5.1 & 94 & 1890 & 1000 & 0.53 & $1.37 \times 10^{-5}$ & $5.85 \times 10^{-6}$ & 0.03 & 0.1614 & 0.0015 & 0.0146 & 0.0002 & 0.0476 & 0.0003 & 0.342 & 0.004 & 0.0522 & 0.0004 & 4293.0 & 3.3 & 299.9 & 1.7 & 299.0 & 2.8 & 299.9 & 1.7 \\
\hline 6.1 & 70 & 1460 & 560 & 0.38 & $3.19 \times 10^{-5}$ & $1.21 \times 10^{-5}$ & 0.06 & 0.1135 & 0.0013 & 0.0141 & 0.0002 & 0.0475 & 0.0003 & 0.337 & 0.004 & 0.0514 & 0.0005 & $5 \quad 283.4$ & 3.8 & 299.4 & 2.0 & 294.6 & 3.2 & 299.8 & 2.0 \\
\hline 7.1 & 71 & 1470 & 630 & 0.43 & $3.70 \times 10^{-6}$ & $2.24 \times 10^{-6}$ & 0.01 & 0.1346 & 0.0011 & 0.0150 & 0.0001 & 0.0475 & 0.0002 & 0.347 & 0.004 & 0.0530 & 0.0006 & 6300.7 & 2.9 & 298.9 & 1.2 & 302.2 & 3.4 & 298.6 & 1.2 \\
\hline 8.1 & 42 & 1250 & 440 & 0.35 & $1.31 \times 10^{-3}$ & $1.28 \times 10^{-4}$ & 2.40 & 0.0727 & 0.0052 & 0.0072 & 0.0005 & 0.0347 & 0.0002 & 0.257 & 0.010 & 0.0537 & 0.0021 & $1 \quad 145$ & 10 & 219.8 & 1.2 & 232.2 & 8.5 & 219.4 & 1.1 \\
\hline 9.1 & 6 & 111 & 54 & 0.49 & $1.44 \times 10^{-4}$ & $1.71 \times 10^{-4}$ & 0.26 & 0.1575 & 0.0084 & 0.0158 & 0.0009 & 0.0491 & 0.0011 & 0.366 & 0.025 & 0.0542 & 0.0034 & $4 \quad 317$ & 18 & 308.7 & 6.9 & 317 & 19 & 308.0 & 6.9 \\
\hline 10.1 & 90 & 1850 & 810 & 0.44 & $1.48 \times 10^{-5}$ & $7.63 \times 10^{-6}$ & 0.03 & 0.1335 & 0.0011 & 0.0147 & 0.0001 & 0.0479 & 0.0002 & 0.349 & 0.005 & 0.0528 & 0.0007 & 7294.1 & 2.6 & 301.4 & 1.0 & 303.7 & 3.8 & 301.2 & 1.1 \\
\hline 11.1 & 8 & 152 & 101 & 0.66 & $8.14 \times 10^{-5}$ & $1.00 \times 10^{-4}$ & 0.15 & 0.2023 & 0.0062 & 0.0148 & 0.0006 & 0.0487 & 0.0010 & 0.376 & 0.019 & 0.0560 & 0.0025 & $5 \quad 298$ & 11 & 306.7 & 6.2 & 324 & 14 & 305.3 & 6.2 \\
\hline 12.1 & 33 & 750 & 660 & 0.88 & $8.75 \times 10^{-4}$ & $9.18 \times 10^{-5}$ & 1.60 & 0.2314 & 0.0051 & 0.0105 & 0.0003 & 0.0396 & 0.0004 & 0.288 & 0.012 & 0.0527 & 0.0020 & 210.4 & 5.0 & 250.4 & 2.2 & 256.7 & 9.3 & 250.3 & 2.2 \\
\hline 13.1 & 87 & 1770 & 810 & 0.46 & $2.00 \times 10^{-5}$ & $2.00 \times 10^{-5}$ & 0.04 & 0.1418 & 0.0019 & 0.0149 & 0.0002 & 0.0480 & 0.0003 & 0.351 & 0.004 & 0.0531 & 0.0005 & $5 \quad 298.2$ & 4.6 & 302.1 & 1.8 & 305.8 & 3.3 & 301.8 & 1.8 \\
\hline 14.1 & 100 & 2000 & 1030 & 0.51 & $2.00 \times 10^{-5}$ & $2.00 \times 10^{-5}$ & 0.04 & 0.1535 & 0.0020 & 0.0144 & 0.0002 & 0.0476 & 0.0003 & 0.339 & 0.005 & 0.0516 & 0.0006 & 6289.6 & 4.4 & 299.6 & 2.0 & 296.2 & 3.5 & 299.8 & 2.0 \\
\hline
\end{tabular}

Abbreviation: * Radiogenic $\mathrm{Pb}$, corrected for common $\mathrm{Pb}$ using ${ }^{204} \mathrm{~Pb}$; f206\%: Percentage of total ${ }^{206} \mathrm{~Pb}$ that is common ${ }^{206} \mathrm{~Pb}$; ${ }^{\wedge}{ }^{206} \mathrm{~Pb} /{ }^{238} \mathrm{U}$ date corrected for common $\mathrm{Pb}$ using ${ }^{207} \mathrm{~Pb}$. 


\section{References}

1. Kryza, R.; Schaltegger, U.; Oberc-Dziedzic, T.; Pin, C.; Ovtcharova, M. Geochronology of a composite granitoid pluton. A high-precision ID-TIMS U-Pb zircon study of the Variscan Karkonosze Granite (SW Poland). Inter. J. Earth Sci. 2014, 103, 683-696. [CrossRef]

2. Machowiak, K.; Armstrong, R. SHRIMP U-Pb zircon age from the Karkonosze granite. Mineral. Pol. Spec. Pap. 2007, 31, 193-196.

3. Kusiak, M.A.; Dunkley, D.J.; Słaby, E.; Martin, H.; Budzyń, B. Sensitive high-resolution ion-microprobe analysis of zircon reequilibrated by late magmatic fluids in a hybridized pluton. Geology 2009, 37, 1063-1066. [CrossRef]

4. Papapavlou, J.; Darling, R.; Moser, D.E.; Barker, I.R.; White, L.F.; Lightfoot, P.C.; Storey, C.D.; Dunlop, J. U-Pb isotopic dating of titanite microstructures: Potential implications for the chronology and identification of large impact structures. Contrib. Mineral. Petrol. 2018, 173, 82. [CrossRef]

5. Mikulski, S.Z.; Stein, H.J. The age of molybdenites in Poland in the light of Re-Os isotopic studies. Biul. Państw. Inst. Geol. 2012, 452, 199-216. (In Polish)

6. Mikulski, S.Z.; Stein, H.J. Re-Os ages for sulphides from the (gold-)polymetallic deposits in the eastern metamorphic cover of the Karkonosze Massif (SW Poland). In Proceedings of the 12th Biennial SGA Meeting on Mineral Deposit Research for a High-Tech World, Uppsala, Sweden, 12-15 August 2013; Jonsson, E., Ed.; Elanders Sverige AB: Uppsala, Sweden, 2013; pp. 217-220.

7. Mikulski, S.Z.; Williams, I.S.; Markowiak, M. Carboniferous-Permian magmatism and Mo-Cu(-W) mineralization in the contact zone between the Małopolska and Upper Silesia Blocks (S Poland)—An echo of Baltica-Gondwana collision. Inter. J. Earth Sci. 2019, 108, 1467-1492. [CrossRef]

8. Stein, H.J.; Markowiak, M.; Mikulski, S.Z. Metamorphic to magmatic transition captured at the Myszków Mo-W deposit, southern Poland. In Mineral Deposit Research: Meeting the Global Challenge; Mao, J., Bierlein, F.P., Eds.; Springer: Berlin/Heidelberg, Germany, 2005; pp. 833-836.

9. Franke, W.; Żelaźniewicz, A. The eastern termination of the Variscides: Terrane correlation and kinematic evolution. In Orogenic Processes: Quantification and Modelling in the Variscan Belt; Franke, W., Haak, U., Oncken, O., Tanner, D., Eds.; Geological Society, London, Special Publications: London, UK, 2000; Volume 179, pp. 63-86.

10. Mazur, S.; Aleksandrowski, P. The Tepla(?)/Saxothuringian suture in the Karkonosze-Izera massif, western Sudetes, central European Variscides. Int. J. Earth Sci. 2001, 90, 341-360. [CrossRef]

11. Mazur, S. Structural and metamorphic evolution of the country rocks at the eastern contact of the Karkonosze granite in the southern Rudawy Janowickie Mts and Lasocki Range. Geol. Sudet. 1995, 29, 31-103. (In Polish)

12. Mazur, S.; Aleksandrowski, P.; Kryza, R.; Oberc-Dziedzic, T. The Variscan Orogen in Poland. Geol. Q. 2006, 50, 89-118.

13. Oliver, G.J.H.; Corfu, F.; Krogh, T.E. U-Pb ages from SW Poland: Evidence for a Caledonian suture zone between Baltica and Gondwana. J. Geol. Soc. Lond. 1993, 150, 355-369. [CrossRef]

14. Oberc-Dziedzic, T.; Kryza, R.; Pin, C.; Mochnacka, K.; Łarionov, A. The Orthogneiss and Schist Complex of the Karkonosze-Izera Massif (Sudetes, SW Poland): U-Pb SHRIMP zircon ages, Nd isotope systematics and protoliths. Geol. Sudet. 2009, 41, 3-24.

15. Wilamowski, A. Geotectonic environment of the Karkonosze and Tatra granite intrusions based on geochemical data. Arch. Mineral. 1998, 51, 261-271.

16. Mikulski, S.Z. Metal ore potential of the parent magma of granite-the Karkonosze massif example. In Granitoids in Poland; Archivum Mineralogie Monograp; Kozłowski, A., Wiszniewska, J., Eds.; KNM PAN, WG UW, PGI-NRI: Warszawa, Poland, 2007; Volume 1, pp. 123-145.

17. Słaby, E.; Martin, H. Mafic and felsic magma interaction in granites: The Hercynian Karkonosze pluton (Sudetes, Bohemian massif). J. Petrol. 2008, 49, 353-391. [CrossRef]

18. Borkowska, M. Pétrographie du granite des Karkonosze. Geol. Sudet. 1966, 2, 1-119. (In Polish)

19. Krentz, O.; Walter, H.; Brause, H.; Hoth, K.; Kozdrój, W.; Cymerman, Z.; Opletal, M.; Mrázová, Š. The Geological Map of Lausitz-Jizera-Karkonosze, 1:100 000 (without Cenozoic Sediments); Sächsisches Landesamt für Umwelt und Geologie/Bereich Boden und Geologie: Freiberg, Germany; Państwowy Instytut Geologiczny: Warszawa, Poland; Český Geologický Ústav: Praha, Czech Republic, 2000. 
20. Kozdrój, W.; Krentz, O.; Opletal, M. (Eds.) Comments on the Geological Map Lausitz-Jizera-Karkonosze (without Cenozoic Sediments) 1:100 000; Wydawnictwa Geologiczne: Warszawa, Poland, 2001; 64p.

21. Awdankiewicz, M.; Awdankiewicz,H.; Kryza, R.; Rodionov, N. SHRIMP zircon study of a micro-monzodiorite dyke in the Karkonosze Granite, Sudetes (SW Poland): Age constraints for late Variscan magmatism in Central Europe. Geol. Mag. 2010, 147, 77-85. [CrossRef]

22. Frost, C.D.; Frost, B.R. On Ferroan (A-type) Granitoids: Their Compositional Variability and Modes of Origin. J. Petrol. 2011, 52, 39-53. [CrossRef]

23. Klomínský, J.; Fediuk, F.; Schovánek, P.; Jarchovský, T. The Krkonoše-Jizera Composite Massif-Never Ending Granite Stories; Czech Geological Survey: Prague, Czech Republic, 2018; 145p.

24. Mierzejewski, M.P. Additional data and remarks to Hans Clooss work in Karkonosze Mts. (Riesengebirge). Zeitsch. Geol. Wissensch. 2002, 30, 37-48.

25. Mierzejewski, M.P.; Pin, C.; Duthou, J.L.; Couturie, J.P. Sr-Nd isotopic study of the Karkonosze granite (Western Sudetes). In Igneous Activity and Metamorphic Evolution of the Sudetes Area; Kryza, R., Ed.; Wrocław University: Wroclaw, Poland, 1994; p. 82.

26. Žák, J.; Klomínský, J. Magmatic structure in the Krkonoše-Jizera Plutonic Complex, Bohemian Massif: Evidence for localized multiphase flow and small-scale thermal-mechanical instabilities in a granitic magma chamber. J. Volc. Geotherm. Res. 2007, 164, 254-267. [CrossRef]

27. Słaby, E.; Götze, J. Feldspar crystallization under magma-mixing conditions shown by cathodoluminescence and geochemical modelling-A case study from the Karkonosze pluton (SW Poland). Mineral. Mag. 2004, 68, 561-577. [CrossRef]

28. Žák, J.; Verner, K.; Sláma, J.; Kachlík, V.; Chlupáčová, M. Multistage magma emplacement and progressive strain accumulation in the shallow-level Krkonoše-Jizera plutonic complex, Bohemian massif. Tectonics 2013, 32, 1493-1512. [CrossRef]

29. Kennan, P.S.; Dziedzic, H.; Lorenc, M.W.; Mierzejewski, M.P. Review of Rb-Sr isotope patterns in the Carboniferous granitoids of the Sudetes in SW Poland. Geol. Sudet. 1999, 32, 49-53.

30. Cieśliński, N.; Żaba, J. Structural position of the Variscan vein rocks in the northern contact zone of the Karkonosze massif in the vicinity of Szklarska Poręba (Western Sudetes). Geol. Sudet. 1990, 25, 59-81.

31. Mochnacka, K.; Oberc-Dziedzic, T.; Mayer, W.; Pieczka, A. Ore mineralization related to geological evolution of the Karkonosze-Izera massif (the Sudetes, Poland)—Towards a model. Ore Geol. Rev. 2015, 64, 215-238. [CrossRef]

32. Pin, C.; Mierzejewski, M.P.; Duthou, J.L. Isochronous age Rb/Sr of Karkonosze granite from the quarry Szklarska Poręba Huta and significance of initial ratio ${ }^{87} \mathrm{Sr} /{ }^{86} \mathrm{Sr}$ in this granite. Prz. Geol. 1987, 35, 512-516.

33. Duthou, J.L.; Couturie, J.P.; Mierzejewski, M.P.; Pin, C. Next dating of granite sample from the Karkonosze Mountains using Rb-Sr total rock isochrone method. Prz. Geol. 1991, 36, 75-79. (In Polish)

34. Marheine, D.; Kachlik, V.; Maluski, H.; Patocka, F.; Żelaźniewicz, A. The Ar-Ar ages from the West Sudetes (NE Bohemian massif): Constrains on the Variscan polyphase tectonothermal development. Palaeozoic Amalgamation of Central Europe (Winchester, J.A., Pharaoh, T.C., Verniers, J., Eds.). Geol. Soc. Lond. Spec. Publ. 2002, 201, 133-155. [CrossRef]

35. Kröner, A.; Hegner, E.; Hammer, J.; Haase, G.; Bielicki, K.; Krauss, M.; Eidam, J. Geochronology and Nd-Sr systematic of Lusatian granitoids: Significance for the evolution of the Variscan orogen in east-central Europe. Geolog. Rund. 1994, 83, 357-376.

36. Kusiak, M.A.; Dunkley, D.J.; Słaby, E.; Budzyń, B.; Martin, H. Metasomatized zircon from the equigranular granite of the Karkonosze Pluton, NE Bohemian Massif. In Proceedings of the MIMET 2008 Conference: Mineral Equilibria, Metasomatism, and Mass Transport: Evolution and Stabilization of Rock on a Fluid-Rick World, Smolenice, Slovakia, 8-11 April 2008; Geological Institute, Slovak Academy of Sciences: Bratislava, Slovakia, 2008; pp. 87-90.

37. Kusiak, M.A.; Dunkley, D.J.; Słaby, E.; Budzyń, B.; Martin, H. U-Pb chronology of zircon from granites of the Karkonosze Pluton, NE Bohemian Massif. In 4th SHRIMP Workshop 29 June-4 July 2008, Abstract Volume: Saint Petersburg, Russia; VSEGEI (Russian Geological Research Institute): St. Petersburg, Russia, 2008; pp. 78-80.

38. Kryza, R.; Crowley, Q.G.; Larionov, A.; Pin, C.; Oberc-Dziedzic, T.; Mochnacka, K. Chemical abrasion applied to SHRIMP zircon geochronology: An example from the Variscan Karkonosze Granite (Sudetes), SW Poland). Gondwana Res. 2012, 21, 757-767. [CrossRef] 
39. Kusiak, M.A.; Williams, I.S.; Dunkley, D.J.; Konečny, P.; Słaby, E.; Martin, H. Monazite to the rescue: U-Th-Pb dating of the intrusive history of the composite Karkonosze pluton, Bohemian Massif. Chem. Geol. 2014, 364, 76-92. [CrossRef]

40. Kryza, R.; Pin, C.; Oberc-Dziedzic, T.; Crowley, O.G.; Larionov, A. Deciphering the geochronology of a large pluton (Karkonosze Granite, SW Poland): An assessment of U-Pb zircon SIMS and Rb-Sr whole-rock dates relative to U-Pb zircon CA-ID-TIMS. Int. Geol. Rev. 2014, 56, 756-782. [CrossRef]

41. Gajda, E. Minerals from pegmatite veins of the region of the Szklarska Poreba (Karkonosze Mts.). Kwart. Geol. 1960, 4, 565-584. (In Polish)

42. Kozłowski, A.; Karwowski, Ł.; Olszyński, W. Tungsten-tin-molybdenum mineralization in the Karkonosze massif. Acta Geol. Pol. 1975, 25, 415-430.

43. Kozłowski, A.; Ilnicki, S.; Matyszczak, W.; Marcinowska, A. Magmatic and post-magmatic phenomena in the Karkonosze granite and its metamorphic envelope (West Sudetes, SW Poland). Acta Geol. Pol. 2016, 66, 451-471. [CrossRef]

44. Olszyński, W.; Kozłowski, Ł.; Karwowski, Ł. Bismuth minerals from the Karkonosze massif. Acta Geol. Pol. 1976, 26, 443-449.

45. Pieczka, A.; Gołębiowska, B. Cuprobismutite homologues in granitic pegmatites from Szklarska Poręba, Karkonosze massif, southwestern Poland. Can. Mineral. 2012, 50, 313-324. [CrossRef]

46. Kozłowski, A.; Matyszczak, W. Oxygenic bismuth minerals in the NE part of the Karkonosze pluton (West Sudetes, SW Poland). Acta Geol. Pol. 2018, 68, 537-554.

47. Mochnacka, K.; Banaś, M. Occurrence and genetic relationships of uranium and thorium mineralization in the Karkonosze-Izera Block (the Sudety Mts., SW Poland). Ann. Soc. Geol. Pol. 2000, 70, 137-150.

48. Karwowski, Ł.; Olszynski, W.; Kozłowski, A. Wolframite mineralization from the vicinity of Szklarska Poreba Huta. Prz. Geol. 1973, 21, 633-637.

49. Kozłowski, A.; Sachanbiński, M. Karkonosze intragranitic pegmatites and their minerals. In Granitoids in Poland, Archivum Mineralogie Monograph; Kozłowski, A., Wiszniewska, J., Eds.; KNM PAN, WG UW, PGI-NRI: Warszawa, Poland, 2007; Volume 1, pp. 155-178.

50. Kozłowski, A. Pneumatolitic and hydrothermal activity In the Karkonosze-Izera block. Acta Geol. Pol. 1978, 28, 171-222.

51. Mikulski, S.Z.; Stein, H.J. Re-Os age for molybdenite from the Variscan Karkonosze massif and its eastern metamorphic cover (SW Poland). In Let's Talk Ore Deposits, Proceedings of the 11th SGA Biennial Meeting, Antofagasta Chile; Barra, F., Reich, M., Campos, E., Tornos, F., Eds.; Ediciones Universidad Católica del Norte: Antofagasta, Chile, 2011; pp. 130-133.

52. Karwowski, Ł.; Włodyka, R.; Kurdziel, M. Conditions of formation of druse minerals from Michałowice (Karkonosze Massif, Southwestern Poland). Arch. Mineral. 1983, 39, $29-39$.

53. Kozłowski, A.; Dzierżanowski, P. Gadolinite from the Michałowice quarry, Karkonosze massif, SW Poland. Mineral. Pol. Spec. Pap. 2007, 31, 187-188.

54. Kozłowski, A. Native gold in the intragranitic pegmatites of the Karkonosze massif. In Gold in Poland. Archivum Mineralogie Monograph; Kozłowski, A., Mikulski, S.Z., Eds.; KNM PAN, WG UW, PGI-NRI: Warszawa, Poland, 2011; Volume 2, pp. 9-25.

55. Kryza, R.; Mazur, S.; Pin, C. Leszczyniec meta-igneous complex in the estearn part of the Karkonosze-Izera Block, Western Sudetes: Trace elements and Nd isotope study. N. Jahr Mineral. Abh. 1995, 170, 59-74.

56. Patočka, F.; Fajst, M.; Kachlík, V. Mafic-felsic to mafic-ultramafic Early Palaeozoic magmatism of the West Sudetes (NE Bohemian Massif): The South Krkonoše Complex. Zeitsch. Geol. Wissensch. 2000, 28, 177-210.

57. Seston, R.; Winchester, J.A.; Piasecki, M.A.J.; Crowley, Q.G.; Floyd, P.A. A structural model for the western-central Sudetes: A deformed stack of Variscan thrust sheets. J. Geol. Soc. Lond. 2000, 157, 1155-1167. [CrossRef]

58. Kozdrój, W. Ewolucja geotektoniczna krystaliniku wschodnich Karkonoszy. In The Western Sudetes: From Vendian to Quaternary; Ciężkowski, W., Wojewoda, J., Żelaźniewicz, A., Eds.; Polskie Towarzystwo Geologiczne, WIND: Wrocław, Poland, 2003; pp. 67-80. (In Polish)

59. Teisseyre, J.H. Geological structure of the metamorphic mantle of the Karkonosze granite in Miedzianka Region (Western Sudetes). Geol. Sudet. 1968, 4, 481-555. (In Polish)

60. Teisseyre, J.H. Metamorphic rocks of the Rudawy Janowickie and Lasocki Grzbiet ranges. Geol. Sudet. 1973, 8, 7-118. (In Polish) 
61. Kozdrój, W.; Turniak, K.; Tichomirova, M.; Bombach, K.; Ziółkowska-Kozdrój, M.; Kachlik, V. New ${ }^{207} \mathrm{~Pb} /{ }^{206} \mathrm{~Pb}$ zircon ages from the East Karkonosze Metamorphic Complex, West Sudetes-evidence of the Late Cambrian-Early Ordovician magmatism. Geolines 2005, 19, 69-70.

62. Winchester, J.A.; Floyd, P.A.; Chocyk, M.; Horbowy, K.; Kozdrój, W. Geochemistry and tectonic environment of Ordovician meta-igneous rocks in the Rudawy Janowickie Complex, SW Poland. J. Geol. Soc. Lond. 1995, 152, 105-115. [CrossRef]

63. Zimnoch, E. Ore mineralization of the Miedzianka deposit in the Sudetes. Biul. Inst. Geol. 1978, 308, 91-122. (In Polish)

64. Zimnoch, E. Occurrence of magnetite in the Miedzianka deposit (Lower Silesia). Bull. de l'Acad. Pol. des Sci. 1976, 26, 133-138.

65. Mochnacka, K.; Oberc-Dziedzic, T.; Mayer, W.; Pieczka, A. Ore mineralization in the Miedzianka area (Karkonosze-Izera Massif, the Sudetes, Poland): New information. Mineralogia 2012, 43, 155-178. [CrossRef]

66. Szałamacha, J.; Szałamacha, M. The Detailed Geological Map of the Sudetes; Janowice Wielkie sheet, 1:25000; Instytut Geologiczny: Warszawa, Poland, 1956.

67. Oberc-Dziedzic, T.; Mochnacka, K.; Mayer, W.; Pieczka, A.; Creaser, R.A.; Góralski, M. Studies on magnetite and pyrite mineralization, and on their early Paleozoic ocean-floor host-rocks from the Leszczyniec Unit (West Sudetes, Poland). Ann. Soc. Geol. Pol. 2011, 81, 133-160.

68. Mikulski, S.Z. Gold in arsenic ore from the Miedzianka copper deposit (Rudawy Janowickie Mountains). Mineral. Pol. Spec. Pap. 2007, 31, 215-218.

69. Siuda, R. Silver minerals from Friederike Juliane Mine at Ciechanowice (Sudety Mts, Poland). Biul. Państ. Inst. Geol. 2012, 448, 315-324.

70. Parafiniuk, J.; Siuda, R.; Borkowski, A. Sulphate and arsenate minerals as environmental indicators in the weathering zones of selected ore deposits, Western Sudetes, Poland. Acta Geol. Pol. 2016, 66, 493-508. [CrossRef]

71. Siuda, R.; Kruszewski, Ł. New data on bayldonite, cornwallite, olivenite and philipsburgite from Miedzianka (Rudawy Janowickie Mts., Sudetes, Poland). Miner. Pol. Spec. Pap. 2006, 28, 202-204.

72. Siuda, R.; Gołębiowska, B. New data on supergene minerals from Miedzianka-Ciechanowice deposit in the Rudawy Janowickie Mountains (Lower Silesia, Poland). Prz. Geol. 2011, 59, 226-234. (In Polish)

73. Zimnoch, E. Ore mineralizations of the Czarnów deposit (Sudety). Rocz. PTG 1985, 53, 289-306.

74. Mikulski, S.Z.; Kozlowski, A.; Speczik, S. Fluid inclusion study of gold-bearing quartz-sulphide veins and cassiterite from the Czarnow As deposit ore (SW Poland). In Mineral Exploration and Research: Digging Deeper; Colin, J.A., Ed.; Irish Association of Economic Geologists: Dublin, Ireland, 2007; pp. 805-808.

75. Mikulski, S.Z. The characteristic and genesis of the gold-bearing arsenic polymetallic mineralization in the Czarnów deposit (Western Sudetes). Biul. Państw. Inst. Geol. 2010, 439, 303-320. (In Polish)

76. Mochnacka, K.; Oberc-Dziedzic, T.; Mayer, W.; Pieczka, A.; Góralski, M. New insights into mineralization of the Czarnów ore deposit (West Sudetes, Poland). Geol. Sudet. 2009, 41, 43-56.

77. Szałamacha, J.; Szałamacha, M. The Detailed Geological Map of the Sudetes; Pisarzowice sheet, 1:25,000; Wydawnictwa Geologiczne: Warszawa, Poland, 1988.

78. Williams, I.S.; Claesson, S. Isotopic evidence for the Precambrian provenance and Caledonian metamorphism of high grade paragneisses from the Seve Nappes, Scandinavian Caledonides. II. Ion microprobe zircon U-Th-Pb. Contr. Min. Petrol. 1987, 97, 205-217. [CrossRef]

79. Williams, I.S. U-Th-Pb Geochronology by Ion Microprobe. Rev. Econ. Geol. 1998, 7, 1-35.

80. Williams, I.S.; Hergt, J.M. U-Pb dating of Tasmanian dolerites: A cautionary tale of SHRIMP analysis of high-U zircon. In Beyond 2000: New Frontiers in Isotope Geoscience; Woodhead, J.D., Hergt, J.M., Noble, W.P., Eds.; University of Melbourne: Melbourne, Australia, 2001; pp. 185-188.

81. Ludwig, K.R. User's Manual for Isoplot 3.00. A Geochronological Toolkit for Microsoft Excel. 2003; Berkeley Geochronology Center Special Publication 4; Berkeley Geochronology Center: Berkeley, CA, USA, 2003.

82. Mikulski, S.Z.; Williams, I.S. Zircon U-Pb dating of igneous rocks in the Radzimowice and Wielisław Złotoryjski auriferous polymetallic deposits, Sudetes, SW Poland. Ann. Soc. Geol. Pol. 2014, 84, 213-233.

83. Awdankiewicz, M.; Kryza, R. The Chełmiec subvolvanic intrusion (Intra-Sudetic Basin, SW Poland): Preliminary SHRIMP zircon age. Mineral. Spec. Pap. 2010, 37, 69.

84. Awdankiewicz, M.; Kryza, R. The Góry Suche Rhyolitic Tuffs (Intra-Sudetic Basin, SW Poland): Preliminary SHRIMP zircon age. Mineral. Spec. Pap. 2010, 37, 70. 
85. Kryza, R.; Awdankiewicz, M. Ambiguos geological position of Carboniferous rhyodacites in the Intra-Sudetic Basin (SW Poland) clarified by SHRIMP zircon ages. Geol. Q. 2012, 56, 55-66.

86. Aleksandrowski, P.; Kryza, R.; Mazur, S.; Żaba, J. Kinematic data on major Variscan strike-slip faults and shear zones in the Polish Sudetes, northeast Bohemian massif. Geol. Mag. 1997, 133, 727-739. [CrossRef]

87. Mikulski, S.Z.; Stein, H.J. Re-Os age for molybdenite from the Western Sudetes, SW Poland. In Granitoids in Poland, Archivum Mineralogie Monograph; Kozłowski, A., Wiszniewska, J., Eds.; KNM PAN, WG UW, PGI-NRI: Warszawa, Poland, 2007; Volume 1, pp. 203-216.

88. Mayer, W.; Creaser, R.A.; Mochnacka, K.; Oberc-Dziedzic, T.; Pieczka, A. Isotopic Re-Os age of molybdenite from the Szklarska Poreba Huta Quarry (Karkonosze, SW Poland). Geol. Q. 2012, 56, 505-512. [CrossRef]

89. Mikulski, S.Z.; Stein, H.J. The Re-Os age for molybdenite from the Variscan Strzegom-Sobótka massif (SW Poland). In Mineral Deposit Research: Meeting the Global Challenge; Mao, J., Bierlein, F.P., Eds.; Springer: Berlin/Heidelberg, Germany, 2005; pp. 789-792.

90. Stein, H.J.; Morgan, J.W.; Scheresten, A. Re-Os of low level highly radiogenic (LLHR) sulfides: The Harnas gold deposit, southwest Sweden, records continental-scale tectonic events. Econ. Geol. 2000, 95, 1657-1671. [CrossRef]

91. Mikulski, S.Z.; Markey, R.J.; Stein, H.J. Re-Os ages for auriferous sulfides from the gold deposits in the Kaczawa Mountains (SW Poland). In Mineral Deposit Research: Meeting the Global Challenge; Mao, J., Bierlein, F.P., Eds.; Springer: Berlin/Heidelberg, Germany, 2005; pp. 793-796.

92. Mikulski, S.Z.; Markey, R.J.; Stein, H.J. The first Re-Os ages of auriferous sulphides from European Variscides. Geochim. Cosmochim. Acta 2005, 69, A572.

93. Ackerman, L.; Haluzová, E.; Creaser, R.A.; Pašava, J.; Veselovsky, F.; Breiter, K.; Erban, V.; Drábek, M. Temporal evolution of mineralization events in the Bohemian Massif inferred from the U-Pbgeochronology of molybdenite. Miner. Depos. 2017, 52, 651-662. [CrossRef]

94. Romer, R.L.; Thomas, R.; Stein, H.J.; Rhede, D. Dating multiply overprinted Sn-mineralized granites-examples from the Erzgebirge, Germany. Miner. Depos. 2007, 42, 337-359. [CrossRef]

(C) 2020 by the authors. Licensee MDPI, Basel, Switzerland. This article is an open access article distributed under the terms and conditions of the Creative Commons Attribution (CC BY) license (http://creativecommons.org/licenses/by/4.0/). 